\title{
Cenozoic Tectonic Reorganizations of the Death Valley Region, Southeast California and Southwest Nevada
}

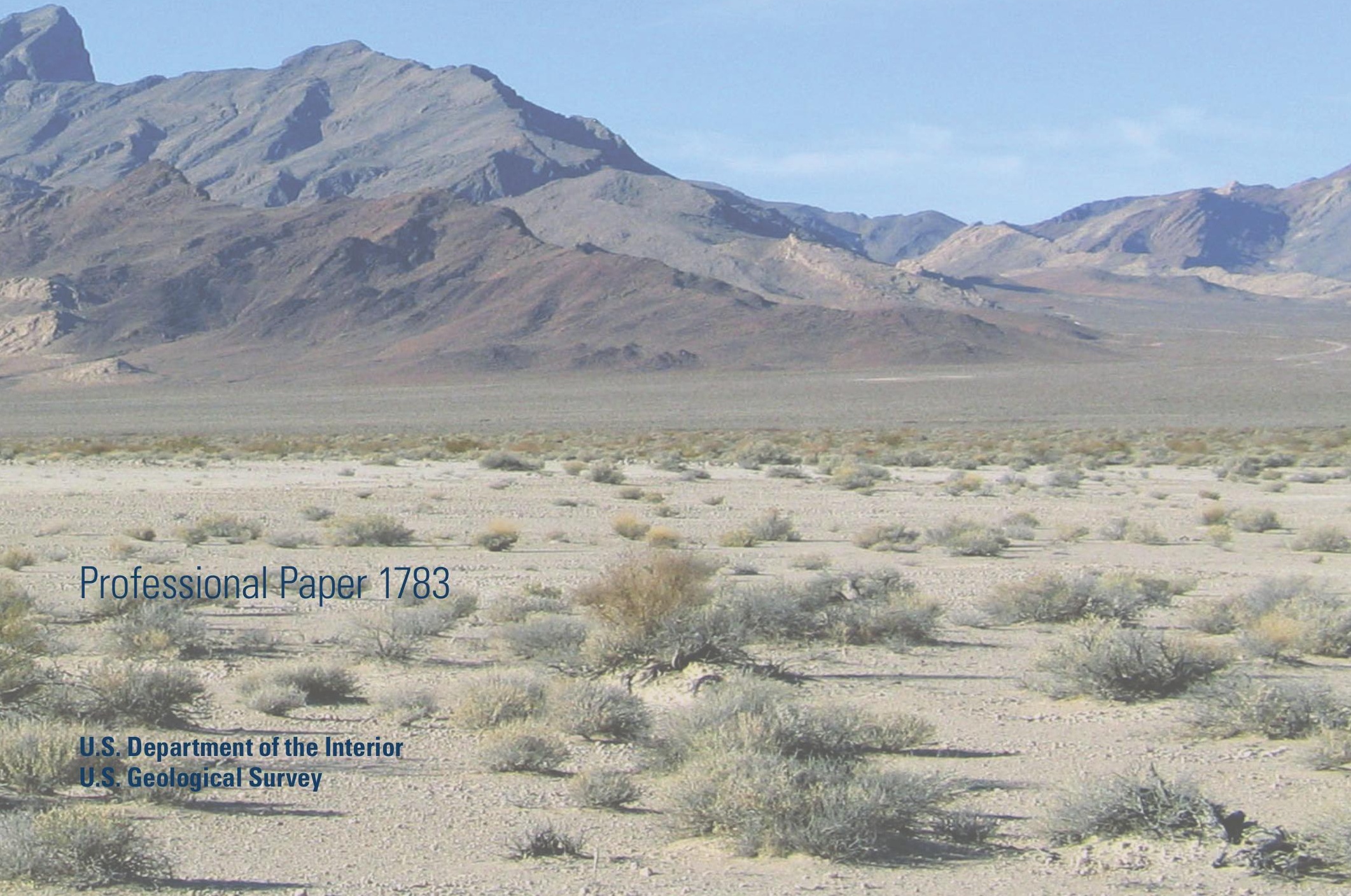


COVER. View of Bat Mountain from the north (photograph by Ren A. Thompson). 


\section{Cenozoic Tectonic Reorganizations of the Death Valley Region, Southeast California and Southwest Nevada}

By Christopher J. Fridrich and Ren A. Thompson

Professional Paper 1783 


\section{U.S. Department of the Interior \\ KEN SALAZAR, Secretary \\ U.S. Geological Survey \\ Marcia K. McNutt, Director}

\section{U.S. Geological Survey, Reston, Virginia: 2011}

For more information on the USGS--the Federal source for science about the Earth, its natural and living resources, natural hazards, and the environment: visit http://www.usgs.gov or call 1-888-ASK-USGS

For an overview of USGS information products, including maps, imagery, and publications, visit http://www.usgs.gov/pubprod

To order this and other USGS information products, visit http://www.store usgs.gov

Any use of trade, product, or firm names is for descriptive purposes only and does not imply endorsement by the U.S. Government.

Although this report is in the public domain, permission must be secured from the individual copyright owners to reproduce any copyrighted materials contained within this report.

Suggested citation:

Fridrich, C.J., and Thompson, R.A., 2011, Cenozoic tectonic reorganizations of the Death Valley region, southeast California and southwest Nevada: U.S. Geological Survey Professional Paper 1783, 36 p. and 1 plate.

\section{Library of Congress Cataloging-in-Publication Data}

Fridrich, C. J. (Christopher J.)

Cenozoic tectonic reorganizations of the Death Valley Region, southeast California and southwest Nevada / by Christopher J. Fridrich and Ren A. Thompson.

p. cm. -- (Professional paper / U.S. Geological Survey ; 1783)

Includes bibliographical references.

ISBN 978-1-4113-3267-6 (pbk.)

1. Morphotectonics--Death Valley Region (Calif. and Nev.) 2. Paleoseismology--Death Valley Region (Calif. and Nev.)

3. Paleoseismology--Cenozoic. 4. Death Valley Region (Calif. and Nev.) I. Thompson, Ren A. II. Geological Survey

(U.S.) III. Title.

OE511.44.F75 2011

551.7'80979487--dc23 


\section{Contents}

Abstract

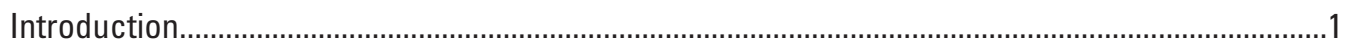

Death Valley Region and Its Boundaries ......................................................................................

Strike-Slip Offsets within the Death Valley Region ..........................................................................

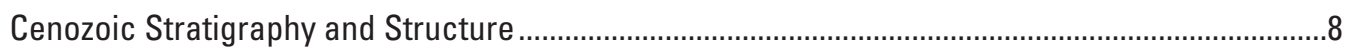

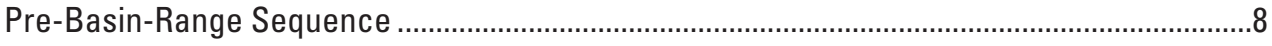

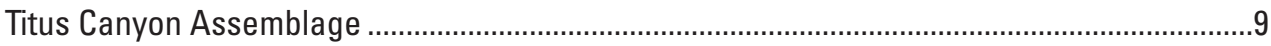

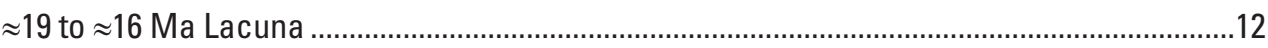

Hells Gate Assemblage of the Hells Gate-Owlshead Tectonic Stage.....................................12

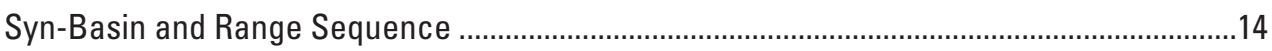

Owlshead Assemblage of the Hells Gate-Owlshead Tectonic Stage ......................................16

The $\approx 12.5$ to $\approx 11.5$ Ma Tectonic Reorganization ........................................................................17

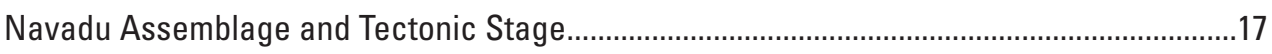

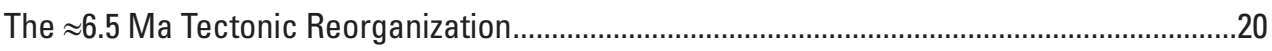

Furnace Creek Assemblage and Tectonic Stage ………...................................................20

The $\approx 4.5$ to $\approx 3$ Ma Tectonic Reorganization ........................................................................

Badwater Assemblage and Tectonic Stage ......................................................................2

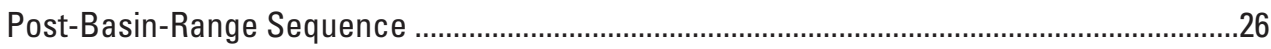

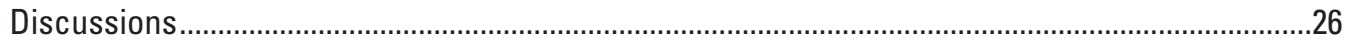

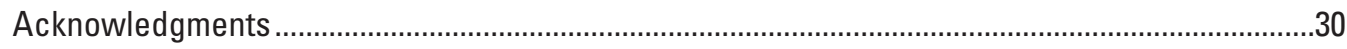

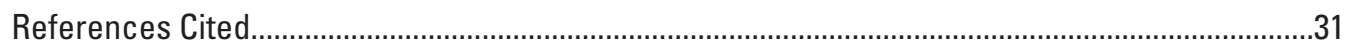

\section{Figures}

1. Death Valley region in relation to the tectonic provinces of the western United States and to the well-documented metamorphic core complexes, modified from Wust, (1986)

2. Physiographic map of the Death Valley region, showing the Sierra Nevada at the western boundary, the Mojave region to the south across the Garlock fault, the Northern Basin and Range block to the northeast across the Las Vegas Valley shear zone (LVVSZ), the outline of the central Death Valley rhombochasm (CDVR), the Resting Spring Range (RSR), the Kingston Range (KR), and the Shadow Valley Basin (SVB)

3. Tectonic map of the Death Valley region showing the major strike-slip faults and the tectonically denuded area of the central Death Valley rhombochasm (CDVR), along with major piercing points that are offset across these structures

4. East-west and chronologic schematic diagram depicting the Cenozoic stratigraphy of the Death Valley region, showing the seven tectono-stratigraphic assemblages...

5. Present-day distribution of the $\geq 40$-to- $\approx 19-$ Ma Titus Canyon assemblage, showing post-depositional boundaries (internal and external) resulting from offsets across the northern Death Valley fault (NDVF) and the Stateline fault system (SF) - offsets which occurred primarily after $\approx 12 \mathrm{Ma}$. 
6. Present-day distributions of the largely coeval pre-basin-range Hells Gate assemblage and syn-basin-range Owlshead assemblage, along with the major faults known to be active during the Hells Gate-Owlshead tectonic stage

7. Structural pattern of the Hells Gate-Owlshead tectonic stage palinspastically restored to correct for post- $\approx 12-\mathrm{Ma}$ extension, and for strike-slip offsets across the southern Death Valley fault (SDVF), Sheephead fault (SHF), northern Death Valley fault (NDVF), and Stateline fault system (SF)

8. Present-day distribution of the $\approx 12$-to- $\approx 7-M a$ syn-basin-range Navadu assemblage, and the major faults known to be active during the Navadu tectonic stage

9. Present-day distribution of the $\approx 7$-to- $\approx 3.5$-Ma syn-basin-range Furnace Creek assemblage, the major faults known to be active, and the distribution and compositions of volcanic rocks erupted in the Furnace Creek stage

10. Present-day distribution of the $\approx 3.5 \mathrm{Ma}$-to-present syn-basin-range Badwater assemblage, the major faults known to be active, and the distribution and compositions of volcanic rocks erupted in the Badwater stage

11. Distribution of the post-basin-range sequence of the Death Valley region, and the estimated ages ( $\mathrm{Ma}$ ) of the strata at the base of this sequence, showing the westward younging of the base age

\section{Plate}

1. Representative Cenozoic stratigraphic columns from 12 locales in the Death Valley region. 


\section{Conversion Factors}

SI to Inch

\begin{tabular}{lll}
\hline Multiply & By & To obtain \\
\hline centimeter $(\mathrm{cm})$ & & \\
millimeter (mm) & 0.3937 & inch (in.) \\
meter (m) & 0.03937 & inch (in.) \\
kilometer $(\mathrm{km})$ & 3.281 & foot (ft) \\
\hline & 0.6214 & mile (mi) \\
\hline square kilometer $\left(\mathrm{km}^{2}\right)$ & & square mile $\left(\mathrm{mi}^{2}\right)$ \\
\hline
\end{tabular}

Temperature in degrees Celsius $\left({ }^{\circ} \mathrm{C}\right)$ may be converted to degrees Fahrenheit $\left({ }^{\circ} \mathrm{F}\right)$ as follows:

${ }^{\circ} \mathrm{F}=\left(1.8 x^{\circ} \mathrm{C}\right)+32$

Temperature in degrees Fahrenheit $\left({ }^{\circ} \mathrm{F}\right)$ may be converted to degrees Celsius $\left({ }^{\circ} \mathrm{C}\right)$ as follows:

${ }^{\circ} \mathrm{C}=\left({ }^{\circ} \mathrm{F}-32\right) / 1.8$

Vertical coordinate information is referenced to the insert datum name (and abbreviation) here, for instance, "North American Vertical Datum of 1988 (NAVD 88)"

Horizontal coordinate information is referenced to the insert datum name (and abbreviation) here, for instance, "North American Datum of 1983 (NAD 83)"

Altitude, as used in this report, refers to distance above the vertical datum 


\section{Acronyms and Abbreviations}

\begin{tabular}{|c|c|}
\hline${ }^{40} \mathrm{Ar} /{ }^{39} \mathrm{Ar}$ & ${ }^{40} \mathrm{Argon} /{ }^{39} \mathrm{Argon}$ (dating) \\
\hline BB & Badwater Basin \\
\hline BU & Black Butte \\
\hline BM & Billie Mine \\
\hline CAV & California Basin \\
\hline $\mathrm{CBH}$ & Central Bullfrog Hills \\
\hline CC & Copper Canyon \\
\hline CDVR & Central Death Valley rhombochasm \\
\hline CFB & Crater Flat Basin \\
\hline $\mathrm{CM}$ & Cottonwood Mountains \\
\hline $\mathrm{cm} / \mathrm{yr}$ & centimeters per year \\
\hline CVB & Chicago Valley Basin \\
\hline CT & Cleary Thrust \\
\hline DSB & Deep Springs Basin \\
\hline EB & Eureka Valley Basin \\
\hline EDF & Emigrant detachment fault \\
\hline FBD & Fluorspar Canyon-Bullfrog Hills detachment fault \\
\hline FCB & Furnace Creek Basin (half-graben) \\
\hline FMD & Funeral Mountains detachment fault \\
\hline HIW & Hole in the Wall (site) \\
\hline GHG & Grand View half-graben \\
\hline GVF & Grand View fault \\
\hline $\mathrm{Ga}$ & Billion years old \\
\hline GM & Grapevine Mountains \\
\hline HD & Harrisburg detachment fault \\
\hline $\mathrm{HH}$ & Holloran Hills \\
\hline IWV & Indian Wells Valley \\
\hline $\mathrm{K}-\mathrm{Ar}$ & Potassium-Argon (dating) \\
\hline KB & Kingston Basin \\
\hline KR & Kingston range \\
\hline KFH & Kit Fox Hills \\
\hline $\mathrm{km}$ & kilometer \\
\hline KPT & Kwichup Peak Thrust \\
\hline
\end{tabular}




\begin{tabular}{|c|c|}
\hline KRD & Kingston Range detachment fault \\
\hline LCR & Last Chance Range \\
\hline LVVSZ & Las Vegas Valley shear zone \\
\hline $\mathrm{m}$ & meter \\
\hline $\mathrm{Ma}$ & million years old \\
\hline MCB & Military Canyon Basin \\
\hline MP & Mormon Point \\
\hline MR & Mushroom Rock (site) \\
\hline NAD & northern segment of Amargosa detachment fault \\
\hline NB & Nova Basin \\
\hline NDVF & Northern Death Valley-Furnace Creek fault \\
\hline NVB & Navadu Basin \\
\hline $\mathrm{OHD}$ & Opera House detachment fault \\
\hline OV & Owens Valley \\
\hline $\mathrm{OM}$ & Owlshead Mountains \\
\hline PB & Pahrump Basin \\
\hline PRD & Point of Rocks detachment fault \\
\hline PVF & Panamint Valley fault \\
\hline RCF & Raven Canyon fault \\
\hline RS & Rodgers Spring \\
\hline RSR & Resting Spring Range \\
\hline RV & Rock Valley \\
\hline RVF & Rock Valley fault \\
\hline SAB & Saline Valley Basin \\
\hline SAD & Southern segment of Amargosa detachment fault \\
\hline SB & Searles Valley Basin \\
\hline SCD & Scottys Castle detachment fault \\
\hline SDVF & Southern Death Valley fault \\
\hline SDVB & Southern Death Valley Basin \\
\hline SEB & Saline-Eureka Valleys area \\
\hline SF & Stateline fault \\
\hline SHF & Sheephead fault \\
\hline SHGB & granite breccia at Sperry Hills \\
\hline SIB & Silurian Valley Basin \\
\hline SNVF & Southwest Nevada volcanic field \\
\hline
\end{tabular}




$\begin{array}{ll}\text { SPT } & \text { Schwaub Peak Thrust } \\ \text { SR } & \text { Specter Range Thrust } \\ \text { SS } & \text { Salt Spring anticline } \\ \text { SV } & \text { Stewart Valley } \\ \text { SVB } & \text { Shadow Valley Basin } \\ \text { TCFS } & \text { Titus Canyon fault system } \\ \text { TLB } & \text { Tecopa Lake beds } \\ \text { TSS } & \text { Texas Spring syncline } \\ \text { USGS } & \text { U.S. Geological Survey } \\ \text { U-Th/He } & \text { Uranium-Thorium/Helium (dating) } \\ \text { VC } & \text { Virgin Canyon } \\ \text { WWF } & \text { Wingate Wash fault }\end{array}$

\section{Symbols}

$\begin{array}{ll}\circ & \text { degrees } \\ \approx & \text { minutes } \\ \geq & \text { approximately } \\ \leq & \text { greater than or equal to } \\ & \text { less than or equal to }\end{array}$




\title{
Cenozoic Tectonic Reorganizations of the Death Valley Region, Southeast California and Southwest Nevada
}

\author{
By Christopher J. Fridrich and Ren A. Thompson
}

\section{Abstract}

The Death Valley region, of southeast California and southwest Nevada, is distinct relative to adjacent regions in its structural style and resulting topography, as well as in the timing of basin-range extension. Cenozoic basin-fill strata, ranging in age from greater than or equal to 40 to approximately 2 million years are common within mountain-range uplifts in this region. The tectonic fragmentation and local uplift of these abandoned basin-fills indicate a multistage history of basin-range tectonism. Additionally, the oldest of these strata record an earlier, pre-basin-range interval of weak extension that formed broad shallow basins that trapped sediments, without forming basin-range topography.

The Cenozoic basin-fill strata record distinct stratigraphic breaks that regionally cluster into tight age ranges, constrained by well-dated interbedded volcanic units. Many of these stratigraphic breaks are long recognized formation boundaries. Most are angular unconformities that coincide with abrupt changes in depositional environment. Deposits that bound these unconformities indicate they are weakly diachronous; they span about 1 to 2 million years and generally decrease in age to the west within individual basins and regionally, across basin boundaries.

Across these unconformities, major changes are found in the distribution and provenance of basin-fill strata, and in patterns of internal facies. These features indicate rapid, regionally coordinated changes in strain patterns defined by major active basin-bounding faults, coincident with step-wise migrations of the belt of active basin-range tectonism. The regionally correlative unconformities thus record short intervals of radical tectonic change, here termed "tectonic reorganizations." The intervening, longer (about 3- to 5-million-year) interval of gradual, monotonic evolution in the locus and style of tectonism are called "tectonic stages."

The belt of active tectonism in the Death Valley region has abruptly stepped westward during three successive tectonic reorganizations that intervened between four stages of basin-range tectonism, the youngest of which is ongoing. These three tectonic reorganizations also intervened between four stages of volcanic activity, each of which has been distinct in the compositions of magmas erupted, in eruption rates, and in the locus of volcanic activity-which has stepped progressively westward, in close coordination with the stepwise migrations in the locus of basin-range extension.

The timing of the Cenozoic tectonic reorganizations in the Death Valley region correlates closely with the documented timing of episodic reorganizations of the boundary between the Pacific and North American plates, to the west and southwest. This supports models that explain the widely distributed transtensional tectonism in southwestern North America since approximately 40 million years ago as resulting from traction imposed by the adjacent, divergent Pacific plate.

\section{Introduction}

This study integrates observations of space-time patterns in the migration of extensional tectonism, related magmatism, and associated basin-fill tectono-stratigraphy of the Death Valley region. The three primary objectives of this study are: (1) to define a Cenozoic stratigraphy of the Death Valley region based on the temporal tectonic evolution, (2) to apply this tectono-stratigraphy to analyze the spatial patterns of Death Valley tectonism from the late Eocene to the present, and (3) to develop an understanding of the processes that underlie the observed pattern of tectonic evolution. The resultant data lead to the interpretation that the migration of extensional tectonism and related volcanism in the Death Valley region (figs. 1 and 2) was punctuated by short [about 1- to 2-millionyear (m.y.)] intervals in which the locus and architecture of tectonic deformation, and the style of volcanism were radically modified, separating longer (about 3- to 5-m.y.) intervals in which tectonic deformation and related volcanism progressed with only gradual, monotonic evolution.

The short intervals of radical change are here termed "tectonic reorganizations," whereas the intervening longer intervals of monotonic evolution are called "tectonic stages." The tectonic reorganizations are recorded in the Cenozoic strata of the region as distinct, regionally correlative stratigraphic breaks, and many of these have long been recognized as formation boundaries. The existence of these regionally correlative unconformities was previously documented in the north-central part of the Death Valley region (Snow and Lux, 


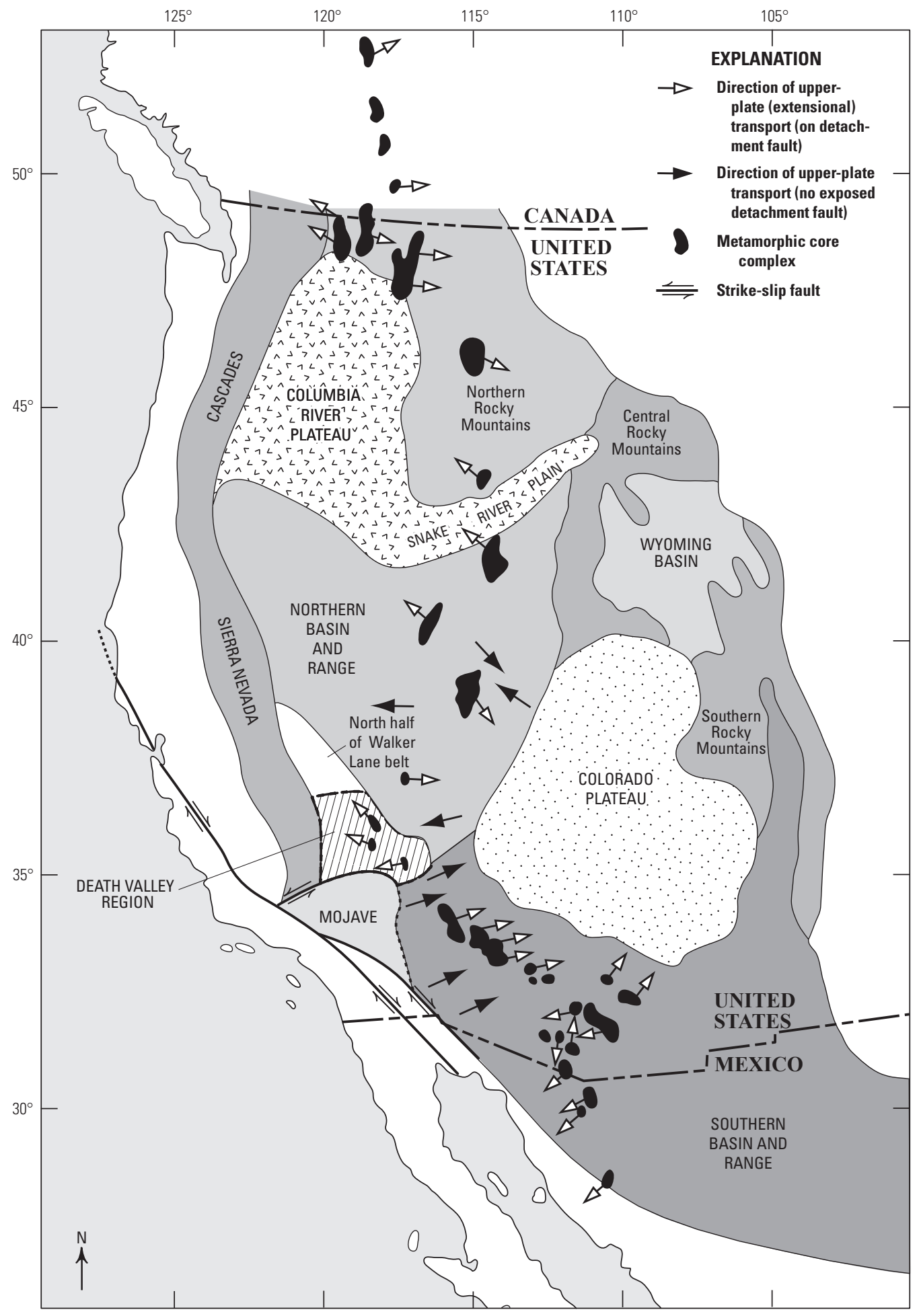

Base modified from U.S. Geological Survey 1:100,000-scale map

Figure 1. Death Valley region in relation to the tectonic provinces of the western United States and to the well-documented metamorphic core complexes, modified from Wust (1986). Death Valley region corresponds to the south half of the Walker Lane belt as defined by Stewart (1988). 


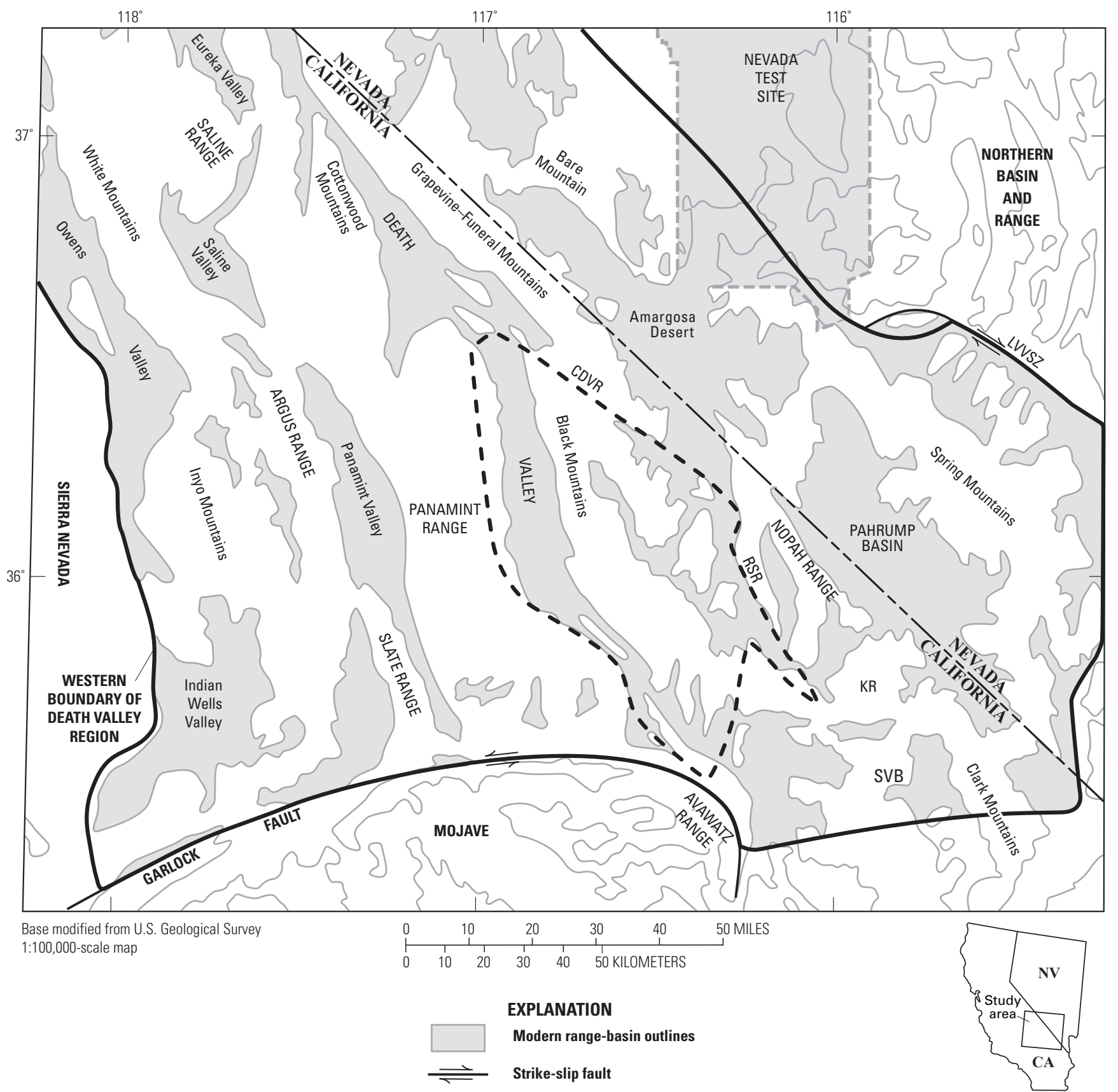

Figure 2. Physiographic map of the Death Valley region, showing the Sierra Nevada at the western boundary, the Mojave region to the south across the Garlock fault, the Northern Basin and Range block to the northeast across the Las Vegas Valley shear zone (LVVSZ), the outline of the central Death Valley rhombochasm (CDVR), the Resting Spring Range (RSR), the Kingston Range (KR), and the Shadow Valley Basin (SVB). 
1999). These stratigraphic boundaries extend throughout the region and perhaps beyond, and their formation coincided with rapid changes in the regional strain regime, and in the locus and style of basin-range tectonism and related volcanism. New data and interpretations are presented based on regional geologic mapping, re-interpretations of previously mapped terrain, and new argon geochronology to examine the role of tectonic reorganizations in the evolution of the Death Valley region. An analysis of the processes that underlie tectonic reorganizations is provided in the summary.

\section{Death Valley Region and Its Boundaries}

The Death Valley domain differs from adjacent regions in structural style and resulting topography. The Cenozoic tectonic history and, consequently, the tectono-stratigraphy have internally consistent temporal and spatial patterns throughout this region. Both are distinctly different even short distances across the boundaries into adjacent regions, at least in terms of when basin-range tectonism began, when and if it has ended, and what the pattern of migration of basin-range tectonism has been. The Death Valley region extends from the southern part of the Nevada Test Site, southward to the Garlock fault, and from the Springs Mountains westward to the eastern front of the Sierra Nevada (figs. 1, 2, and 3). These boundaries are similar to those of the south half of the Walker Lane belt, as defined by Stewart (1988). Stewart documented that the Walker Lane belt has a structural grain that reflects strike-slip strain that is greater in magnitude, or different in sense, than that in the surrounding regions. The north half of Stewart's Walker Lane belt is not included in this study, partly because it has an older (pre- $\sim 16 \mathrm{Ma}$ ) history of basin-range extension that is absent in the south half.

Tectonic timing in the bordering Mojave region (figs. 1 and 2), southward across the Garlock fault, differed radically from that of the Death Valley region. Basin-range extension ended in the Mojave shortly before it began in the Death Valley region (Glazner and others, 2002). Moreover, the direction of migration of basin-range tectonism in the Mojave was northeastward, in contrast to the westward migration indicated in the Death Valley region. Further, the Cenozoic pattern of strike-slip strain in the Mojave is sinistral, whereas in the Death Valley region, it is dextral.

The Spring Mountains (fig. 2), which constitute a large, nearly unextended block, separate the Death Valley region from the Lake Mead region and the northern Colorado River extensional corridor, to the east and southeast (fig. 1). Basinrange extension began in the Lake Mead region earlier than in the Death Valley region, and the locus of tectonism migrated to the north-northwest between about $\approx 19$ to $\approx 8 \mathrm{Ma}$ (Faulds and others, 1999).
The northeastern boundary of the Death Valley region is the same as that of the Walker Lane belt through the southern part of the Nevada Test Site, and the specific trace of this boundary (fig. 2), is based on structural and paleomagnetic data (Minor and others, 1997; Hudson and others, 1994). Southeast of the Nevada Test Site, this boundary follows the Las Vegas Valley shear zone (fig. 2). Northeast of this shear zone, in the southernmost part of the Northern Basin and Range block, the Cenozoic strata record an earlier $(\approx 19 \mathrm{Ma})$ onset of basin-range extension, as discussed below.

The eastern front of the Sierra Nevada forms the western boundary of the Death Valley region (figs. 1 and 2), as well as that of the Basin and Range Province as a whole. The part of the region between this range front and Panamint Valley (figs. 1 and 2) received much less attention in this study; consequently additional data from this area may result in revision of some details presented here.

\section{Strike-Slip Offsets within the Death Valley Region}

Strong transtensional deformation within the Death Valley region is constrained by offsets of numerous oncecontinuous, or once-adjacent features that have been correlated across the major Cenozoic strike-slip and detachment faults of the region (fig. 3). These offset features include late Paleozoic through (mainly) Mesozoic thrust faults (Stewart, 1983; Snow and Wernicke, 2000), isopachs of strongly westwardthickening Neoproterozoic and Cambrian formations (Stewart, 1983), Mesozoic intrusive boundaries (Burchfiel and others, 1987; Carl and Glazner, 2002), and proximal sedimentary and volcanic facies in certain Cenozoic strata that are found far from their source areas (for example, see Brady, 1986). When deformation is restored across the major Cenozoic strike-slip faults, these correlative features must be rejoined. The single major constraint that this restoration provides is that a large, generally rhombus-shaped area in the center of the Death Valley region, herein referred to as the central Death Valley rhombochasm (CDVR; figs. 2 and 3), almost completely closes (Stewart, 1983).

Stewart (1983) proposed that the central Death Valley rhombochasm is a basin that is floored by a tectonically denuded, and originally west-dipping detachment fault. Thus, the rocks exposed in the Panamint Range, on the west side of the central Death Valley rhombochasm, constitute an upper plate that restores southeastward, over the area of this supradetachment basin and against the Resting Spring Range (RSR; on fig. 2), on the east side of the rhombochasm. A thick Neoproterozoic and Paleozoic miogeoclinal section is exposed in the Resting Spring and Panamint Ranges, but is absent within all but the easternmost part of the central Death Valley rhombochasm, where only fragments of it are preserved and exposed - as small, strongly tilted fault blocks and as widely 
Figure 3. Tectonic map of the Death Valley region showing the major strike-slip faults and the tectonically denuded area of the central Death Valley rhombochasm (CDVR), along with major piercing points that are offset across these structures. Offset features include: (1) correlated thrust fault segments, (2) two isopachs and a pinchout of key formations (Stewart, 1983; Snow and Wernicke, 2000), (3) offset Mesozoic intrusions (Burchfiel and others, 1987; Carl and Glazner, 2002), and (4) offset Tertiary features. The major strike-slip faults include the Panamint Valley fault (PVF), the southern Death Valley fault (SDVF), the Sheephead fault (SHF), the northern Death Valley fault (NDVF), the Stateline fault system (SF), and the Las Vegas Valley shear zone (LVVSZ). Other faults shown include the Wingate Wash fault (WWF), the northern and southern segments of the Amargosa detachment fault (NAD and SAD), the Kingston Range detachment fault (KRD), and the Rock Valley fault (RVF). RV, Rock Valley. Offset Tertiary features include the two segments of the Raven Canyon fault (RCF), the proximal granite breccia at Sherry Hills (SHGB) and its source the granite at Kingston Peak, and the boulder conglomerates of the Military Canyon Basin (MCB) that were derived from the gneiss of the Holloran Hills (HH; Brady, 1986). SVB, Shadow Valley Basin; SV, Stewart Valley. The southwest Nevada volcanic field (SNVF) straddles the northern boundary of the Death Valley region.

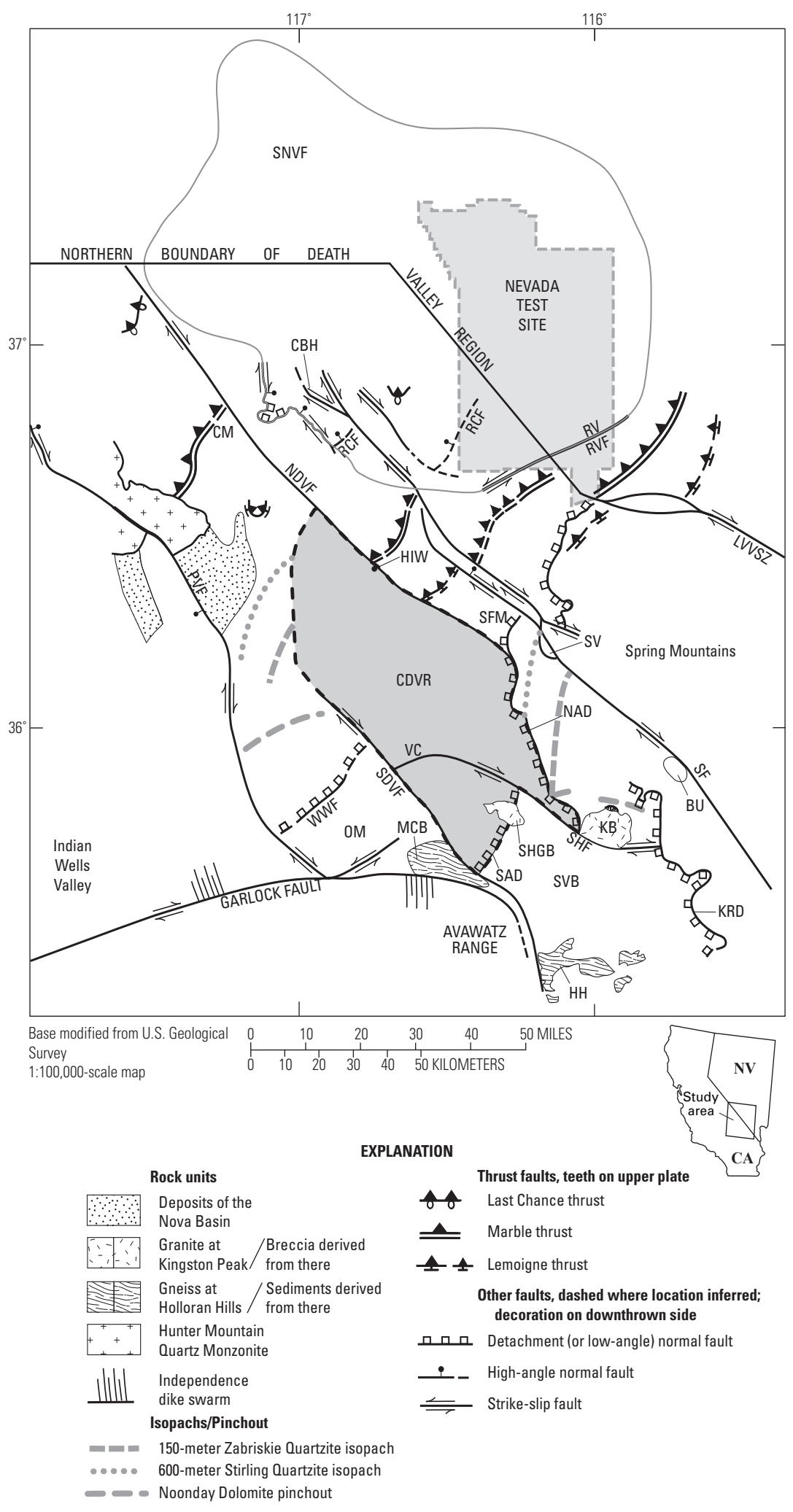


scattered breccia masses. Moreover, the rocks that underlie the Tertiary basin-fill in the central Death Valley rhombochasm evidently are a core-complex of metamorphic and intrusive rocks. Uplift ages on the metamorphic rocks indicate that large-scale tectonic denudation and uplift of the basin floor occurred during the time of strongest local basin-range tectonism, between about 14 and $7 \mathrm{Ma}$ (Holm and others, 1992).

The strike-slip faults of the Death Valley region (fig. 3) are Cenozoic, with only one possible exception, discussed below. Therefore, offsets of pre-Tertiary features, such as thrust faults and isopachs, constrain the total offsets across the strike-slip faults, which can be compared to the offsets of Tertiary features of various ages. These comparisons provide some evidence of the timing of major slip on the strike-slip faults. Six examples follow:

(1) The Sheephead fault (SHF; fig. 3) offsets two large Tertiary granite bodies adjacent to, but on opposite sides of this fault. The granites are indistinguishable petrographically, and intrude the same host rocks. One is the granite at Kingston Peak ( $\approx 12.5 \mathrm{Ma}$; Friedmann, 1999), which is a spectacular cliff-former. The other is the granite at Sperry Hills, which barely starts up in relief against the $\approx 12$ to 8 Ma moderately consolidated alluvial conglomerates and playa claystones that surround it. The granite at Sperry Hills is a proximal rockavalanche deposit, based on ubiquitous brecciation, giant (as much as 100s of meters) clast size, and local exposure of Miocene sedimentary strata beneath it. The current separation between the two granite bodies suggests that the Sheephead fault has about 20 kilometers $(\mathrm{km})$ of right-lateral offset in this locale, all of which was incurred between $\approx 12.5$ Ma (the age of the granite at Kingston Peak) and $\approx 7 \mathrm{Ma}$, the age of initiation of younger faults that crosscut the Sheephead fault in the area of Virgin Canyon (VC, fig. 3).

(2) Brady (1986) documented that the southern Death Valley fault (SDVF; fig. 3) has a minimum of $25 \mathrm{~km}$ of right-lateral offset based on the distance between proximally derived conglomerate in the Military Canyon Basin (MCB, fig. 3) containing large subangular boulders of 1.7 Ga gneiss, and the source of these boulders in the Holloran Hills $(\mathrm{HH}$; bottom-center; fig. 3), on the opposite side of the fault. The boulder conglomerate dates from $\approx 11 \mathrm{Ma}$, based on available K-Ar ages (Brady and Troxel, 1999). Offsets of pre-Tertiary features across the southern Death Valley and Sheephead faults, together, are estimated roughly at $70 \mathrm{~km}$ (fig. 3), and thus are perhaps $50 \mathrm{~km}$ on the southern Death Valley fault alone. Whereas Brady's (1986) $25 \mathrm{~km}$ estimate is a minimum, the boulder conglomerate is unlikely to be offset by $50 \mathrm{~km}$; hence, significant slip evidently occurred on this fault before $\approx 11$ Ma. However, $\approx 14$ Ma volcanic rocks found near the Wingate Wash fault (WWF; fig. 3) are similar to volcanic rocks of the same age exposed $\approx 50 \mathrm{~km}$ to the southeast, on the opposite side of the southern Death Valley fault, suggesting there was little or no offset before $\approx 14$ Ma. Right-lateral offsets of early Quaternary features across the fault indicate a recent slip rate $(\sim 0.03 \mathrm{~cm} / \mathrm{yr}$; Machette and others, 2001) that is more than an order of magnitude lower than the evident rate in the Miocene.

(3) Evidence of similar timing is found along the northern Death Valley-Furnace Creek fault (NDVF; fig. 2). Specifically, pre-basin-range strata in the Cottonwood Mountains (CM; fig. 3) are strikingly similar, in lithology, provenance, and other features, to those of the southern Funeral Mountains (SFM; fig. 3), on the opposite side of the fault. Thus, it appears probable that offset on this fault was lacking or minor before the advent of basin-range tectonism in the central part of the region, at $\approx 14 \mathrm{Ma}$. Alluvial conglomerates and sandstones dated at $\geq 13.5 \mathrm{Ma}$ in the southern Funeral Mountains thicken and coarsen toward the Furnace Creek fault, indicating this fault began to move at $\approx 14 \mathrm{Ma}$. Pre-Cenozoic features indicate $\approx 80 \mathrm{~km}$ of total right-lateral offset across the northern Death Valley-Furnace Creek fault at the northwestern tip of the central Death Valley rhombochasm (fig. 3; Stewart, 1983).

At a site called Hole-in-the-Wall (HIW; fig. 3), Blair and Raynolds (1999) estimated that $\approx 8 \mathrm{~km}$ of right-lateral offset across the Furnace Creek segment of the northern Death Valley-Furnace Creek fault occurred after deposition of basal conglomerates of the Furnace Creek Formation (dating from $\approx 6.5 \mathrm{Ma}$ ). Further, their study concluded that significant strikeslip offset ended at this site by the end of deposition of this formation (at $\approx 3.5 \mathrm{Ma}$; both the $\approx 6.5$ and the $\approx 3.5 \mathrm{Ma}$ estimates are based on new data collected in this study). Blair and Raynolds' estimates are not strictly comparable with the $\approx 80$ $\mathrm{km}$ total offset, above, because the southeasternmost part of the northern Death Valley segment of the fault, in the northwestern part of the central Death Valley rhombochasm, is still active, and has incurred a maximum of $\approx 10 \mathrm{~km}$ of right-lateral offset since $\approx 7 \mathrm{Ma}$, during the opening of Badwater Basin (that part of Death Valley physiographic feature that lies along the western side of the central Death Valley rhombochasm; fig. 2). Adding these figures, perhaps 18 of the total $80 \mathrm{~km}$ of rightlateral offset across the northern Death Valley-Furnace Creek fault has occurred in the last 7 m.y., whereas the remainderthe vast majority-occurred between $\approx 14$ and $\approx 7$ Ma.

(4) The fourth example is along the Stateline fault system (SF; fig. 3) in the southwestern part of the Nevada Test Site and west of there, across the Amargosa Desert Basin. Two fault exposures are found on either side of this basin, both identified here as the Raven Canyon fault system (RCF; fig. 3 ). If the correlation of the two is correct, northwest-striking strike-slip faults in the Amargosa Desert Basin (the Stateline fault system) offset this feature by about $25 \mathrm{~km}$ right-laterally, roughly the same as the offset of pre-Tertiary features in the same area. The basis of correlation is similarity in structural style, timing of slip, and presence of unique volcanic facies (R. Warren, retired, Los Alamos Labs, oral commun., 2003) immediately downthrown on the Raven Canyon fault on either side of the Amargosa Desert, but nowhere else. The Raven Canyon fault system is buried upsection by tuffs dated at $\approx 13$ Ma on both sides of the Stateline fault, thus most if not all offset on the Stateline fault system postdates $\approx 13 \mathrm{Ma}$. 
Two other constraints are known on the timing of the Stateline fault. First, alluvial conglomerates containing a tuff dated at $\approx 11.5 \mathrm{Ma}$ (R. Fleck, USGS, Menlo Park, CA; unpub. data, about 1985), near the base, show strongly fanning dips perpendicular to this fault adjacent to the Black Butte pressure ridge (BB; fig. 3) in the southern part of the Pahrump Basin. The rocks uplifted in the pressure ridge are syntectonic rock-avalanche breccias and intercalated volcanic and lacustrine rocks, dating from $\approx 14.5$ to $\approx 14 \mathrm{Ma}$ (R. Fleck, unpub. data, about 1985). These rocks are strongly tilted and weakly folded, but lack evident fanning dips. The progressive syndepositional tilting of the younger sequence was evidently related to motion on the fault, strong fault offset started by $\approx 12 \mathrm{Ma}$.

Second, in an area about halfway between Raven Canyon and Black Butte, Burchfiel and others (1983) estimated that the Stateline fault has a right-lateral offset of $\approx 3 \mathrm{~km}$ based on offset of a middle through late Miocene $(\approx 12$ to $\approx 7 \mathrm{Ma})$ structure across the fault at the north end of Stewart Valley (SV; fig. 3). The offset structure is one of three structures of differing character that Burchfiel and others (1983) mistakenly lumped as the Six-mile "thrust" (Workman and others, 2004). The 3-kilometer estimate is a minimum because it does not account for possible post- $\approx 7$ Ma offset across another strand of the Stateline fault located $\approx 1$ kilometer to the west, which was the major strand in the Miocene, but a minor strand since then. The 3-kilometer estimate represents the majority of the post$\approx 7$ Ma offset across the Stateline fault in this area. Combined with the above constraints, this suggests that major slip on the Stateline fault began at $\approx 12 \mathrm{Ma}$, and the majority of total offset occurred by $\approx 7 \mathrm{Ma}$. The Stateline fault is still active (Menges and others, 2003) from the south-central part of the Amargosa Desert Basin southeastward through the Pahrump Basin.

(5) The fifth example is in the central Bullfrog Hills (CBH; fig. 3), where there is an inactive offshoot of the Stateline fault. A gently arcuate valley in this area extends the entire north-south span of the Bullfrog Hills. This valley is interpreted as the trace of a strike-slip fault because it juxtaposes strongly differing volcanic facies. For example, the $12.8 \mathrm{Ma}$ Topopah Springs Tuff thins westward and eventually pinches out across the eastern Bullfrog Hills, but then abruptly reappears across this valley and is relatively thick in the western Bullfrog Hills. Likewise, an $\approx 11.7$ Ma unit of the Timber Mountain Group (as redefined by Fridrich and others, 2007; in press) known as the "pre-Rainier rhyolite" changes westward from proximal to distal character across the eastern Bullfrog Hills. This unit is then proximal in character in the western Bullfrog Hills, immediately westward of the long, arcuate fault valley. The offset facies patterns across the Bullfrog Hills indicate that the fault in the central Bullfrog Hills has a minimum right-lateral offset of $\approx 10 \mathrm{~km}$, post-11.7 Ma.

Strong extension-related tilting of Miocene strata in the central Bullfrog Hills is buried upsection. Immediately east of the arcuate fault valley, strata dating from $\geq 11 \mathrm{Ma}$ are tilted as much as $50^{\circ}$ and dips then decline upsection to $\leq 10^{\circ}$ at the $\approx 9 \mathrm{Ma}$ level. Immediately west of the valley, Tertiary strata dating from $\approx 9 \mathrm{Ma}$ are tilted as much as $70^{\circ}$, and dips then decline upsection to $\leq 10^{\circ}$ at the $\approx 7.5 \mathrm{Ma}$ level (Maldonado, 1990; Maldonado and Hausback, 1990; Fridrich, unpub. data, 2005 ). The $\approx 7.5$ Ma rocks are overlain, without evident disconformity, by untilted alluvial conglomerates that fill the arcuate valley and, although poorly exposed, show no evidence of being faulted. Thus, the strike-slip faulting in the central Bullfrog Hills occurred largely if not entirely within the $\approx 11.7$ to $\approx 7$ Ma interval.

(6) Deposits of the Nova Basin - that major part of the Nova Formation (Snyder and Hodges, 2000) that ranges in age from $\approx 7$ to $\approx 3 \mathrm{Ma}$ - are exposed on either side of the Panamint Valley fault (PVF; fig. 3). These strata are offset right-laterally to the same degree as the southeastern contact of the Jurassic Hunter Mountain Quartz Monzonite pluton. Thus, the Panamint Valley fault evidently has been active only since $\approx 3 \mathrm{Ma}$.

Whereas much of the information above is only semiquantitative, some generalizations can be made:

First, the timing of major slip on all of the large strikeslip faults within the Death Valley region is within the $\approx 16 \mathrm{Ma}$ to present interval of basin-range extension.

Second, only the northern Death Valley-Furnace Creek fault and the southern Death Valley fault show clear evidence of slip in the $\approx 14$ to $\approx 12 \mathrm{Ma}$ interval. Additional information about the slip histories of these two faults is recorded in the basin-fill deposits in the central Death Valley rhombochasm because the opening of this feature was directly related to slip on these two bounding strike-slip faults. In combination, the data indicate the majority of slip on both of these faults occurred between $\approx 12$ and $\approx 7 \mathrm{Ma}$, with significantly lower slip rates before and after. Slip on the Sheephead fault and on the unnamed strike-slip fault in the central Bullfrog Hills was entirely confined to the $\approx 12$ to $\approx 7$ Ma interval.

Third, the Panamint Valley fault alone is quite young $(\approx 3 \mathrm{Ma})$. The slip rate on this fault has been much smaller than the average slip rates for the northern and southern Death Valley faults, but is comparable to the post $\approx 7$ Ma slip rates for both of those faults.

The above discussion leaves out strike-slip faults that form parts of the boundaries of the Death Valley region, namely the Las Vegas Valley shear zone, and the Garlock and Owens Valley faults. The Las Vegas Valley shear zone can be viewed as being, at least partly, an accommodation zone between the nearly unextended Spring Mountains block and the strongly extended area immediately to the northeast across this fault. The timing of that extension to the northeast is recorded by fanning dips in syntectonic basin-fill strata. Synbasin-range deposits in this area include strongly tilted basal rock-avalanche breccias, derived from adjacent range-front fault scarps, and these breccias are intercalated with two tuffs, which were sampled. Based on detailed petrography, R. Warren (retired, Los Alamos National Labs, written commun., 2002), identified these units as the $\approx 19$ Ma tuff of Twin Peaks and the $\approx 18.5$ Ma Hiko Tuff. The two major tuffs of the Timber Mountain Group (dated at 11.6 and 11.45 Ma; Sawyer and others, 1994) are intercalated near the tops of the same basin-fill sections and are only tilted $\approx 10^{\circ}$. Thus, 
basin-range extension in this area began at $\approx 19 \mathrm{Ma}$ and was winding down by $\approx 11 \mathrm{Ma}$. As a first-order estimate, data suggests that the timing on the Las Vegas Valley shear zone is the same; however, this major strike-slip fault may be more than just an accommodation zone, and may thus have a longer and more complex history than is suggested by this evidence.

Based on recent detailed mapping and analysis by Andrew and others (2010), motion on the Garlock fault initiated between $\approx 18$ and $\approx 15 \mathrm{Ma}$, and resulted in $\approx 15 \mathrm{~km}$ of leftlateral offset by $\approx 12 \mathrm{Ma}$. This was followed by a hiatus, with little or no offset between $\approx 12$ and $\approx 6 \mathrm{Ma}$. Slip restarted as early as $\approx 6 \mathrm{Ma}$, but the current high rate of slip probably did not begin until $\approx 3 \mathrm{Ma}$. Total slip since $\approx 6 \mathrm{Ma}$ has been $\approx 50 \mathrm{~km}$, for a total left-lateral offset (of the Independence dike swarm; fig. 3) of $\approx 65 \mathrm{~km}$ (Carl and Glazner, 2002).

The northern part of Owens Valley (in the northern half of the Walker Lane belt; fig. 1) did not form until $\approx 3 \mathrm{Ma}$ (Henry and others, 2007). The southern part of Owens Valley, however, contains syntectonic basin fill as old as $\approx 6 \mathrm{Ma}$ (Duffield and others, 1980), as discussed below; however, the major basin subsidence even in the southern part of this basin evidently has been from $\approx 3 \mathrm{Ma}$ to present. Whereas total rightlateral offset across the Owens Valley fault is estimated at $\approx 65 \mathrm{~km}$, it is unclear how much of this offset is Tertiary and how much may be Mesozoic (see Phillips, 2009, and references therein).

In addition to the major strike-slip faults, there is evidence for some large-scale steep-axis folding across the northern part of the Death Valley region that reflects dextral oroflexural bending, and that deforms the Mesozoic thrust faults. In the major area of oroflexure, in and around Rock Valley (RV; fig. 3), paleomagnetic results indicate that the bending predates the local volcanic rocks, including the 13.3 Ma Bullfrog Tuff (Hudson and others, 1994). It, thus, also predates the onset of basin-range extension in this part of the region. This pre-basin-range oroflexure is a product of strike-slip deformation, but only limited strike-slip faulting was involved; and structures associated with basin-range extension cut across it. The oroflexure in and around Rock Valley lies immediately beyond the northwest termination of the Las Vegas Valley shear zone, and appears to be related to it geometrically. If so, this shear zone formed in the pre-basin-range interval.

\section{Cenozoic Stratigraphy and Structure}

The Cenozoic basin-fill stratigraphy of the Death Valley region provides the principal record of the tectonic evolution of this region during the last $\geq 40$ m.y. The following regional tectono-stratigraphic classification (fig. 4) is, partly, a modification of one proposed by Snow and Lux (1999).

The Cenozoic rocks of the Death Valley region are divided into three sequences: (1) pre-basin-range ( $\geq 40$ to $\approx 12 \mathrm{Ma}$ ), (2) syn-basin-range ( $\approx 16 \mathrm{Ma}$ to present), and
(3) post-basin-range $(\leq 12 \mathrm{Ma}$ to present; see inset figure, bottom-center of fig. 4). These three sequences are strongly diachronous, and are younger to the west. Two of these sequences are divided by regional unconformities into assemblages. Discussion of the seven allostratigraphic units of the region are presented in conjunction with maps (figs. 5 to 11) showing the distribution of each unit, the major active faults in each corresponding tectonic stage, and the distribution and composition of associated volcanic rocks. Also shown are calderas formed in voluminous ash-flow tuff eruptions, and some large folds that have locally formed in the Cenozoic rocks (fig. 10).

\section{Pre-Basin-Range Sequence}

The pre-basin-range sequence of the Death Valley region is divided by the $\approx 19$ to $\approx 16$ Ma lacuna into the older, $\geq 40$ to $\approx 19 \mathrm{Ma}$ Titus Canyon and the younger, $\approx 16$ to $\approx 12 \mathrm{Ma}$ Hells Gate assemblages (fig. 4). The Hells Gate assemblage is restricted to the areas of the Titus Canyon and Ubehebe Basins, defined below (and see figs. 6 and 7), and everywhere overlies the Titus Canyon assemblage where the base is exposed. In contrast, isolated paleocanyon fills of Titus Canyon assemblage are locally found in several widely scattered locations far beyond the Titus Canyon and Ubehebe Basins (fig. 5). Subtle differences in the provenance of the two pre-basin-range assemblages indicate only minor change in the tectonic architecture and resulting topography during the $\approx 19$ to $\approx 16 \mathrm{Ma}$ interval of nondeposition.

A defining feature of the pre-basin-range sequence is the distal provenance of the predominantly fluvial sedimentary rocks that compose it. Rivers carried clasts, including ones of Mesozoic igneous rocks found only in the western part of the region, eastward at least to the east-central part of the region. Fluvial transport was occurring across a broad area that is now interrupted by several mountain ranges and intervening closed basins. Thus, the earliest interval of Cenozoic extension formed broad shallow basins that trapped sediments, but evidently predated the formation of basin-range topography. Syndepositional, extension-related tilting is rare within the pre-basin-range sequence, in contrast to the syn-basin-range sequence, in which fanning dips and local internal unconformities are common.

Proximal conglomerates and breccias are locally present in the basal Titus Canyon assemblage, but they are volumetrically minor. Distally derived detritus makes up the remainder of the sedimentary component of both pre-basin-range assemblages, excluding locally derived volcaniclastic material in the Hells Gate assemblage. In contrast, most sedimentary strata in the syn-basin-range assemblages are proximal in character.

In a small area in the northeastern part of the region, in Rock Valley (RV; fig. 5), the fluvial sediments in the pre-basin-range sequence are derived from the east (Murray, 2002), instead of from the west. And in a narrow corridor between the areas of easterly and westerly provenance, 


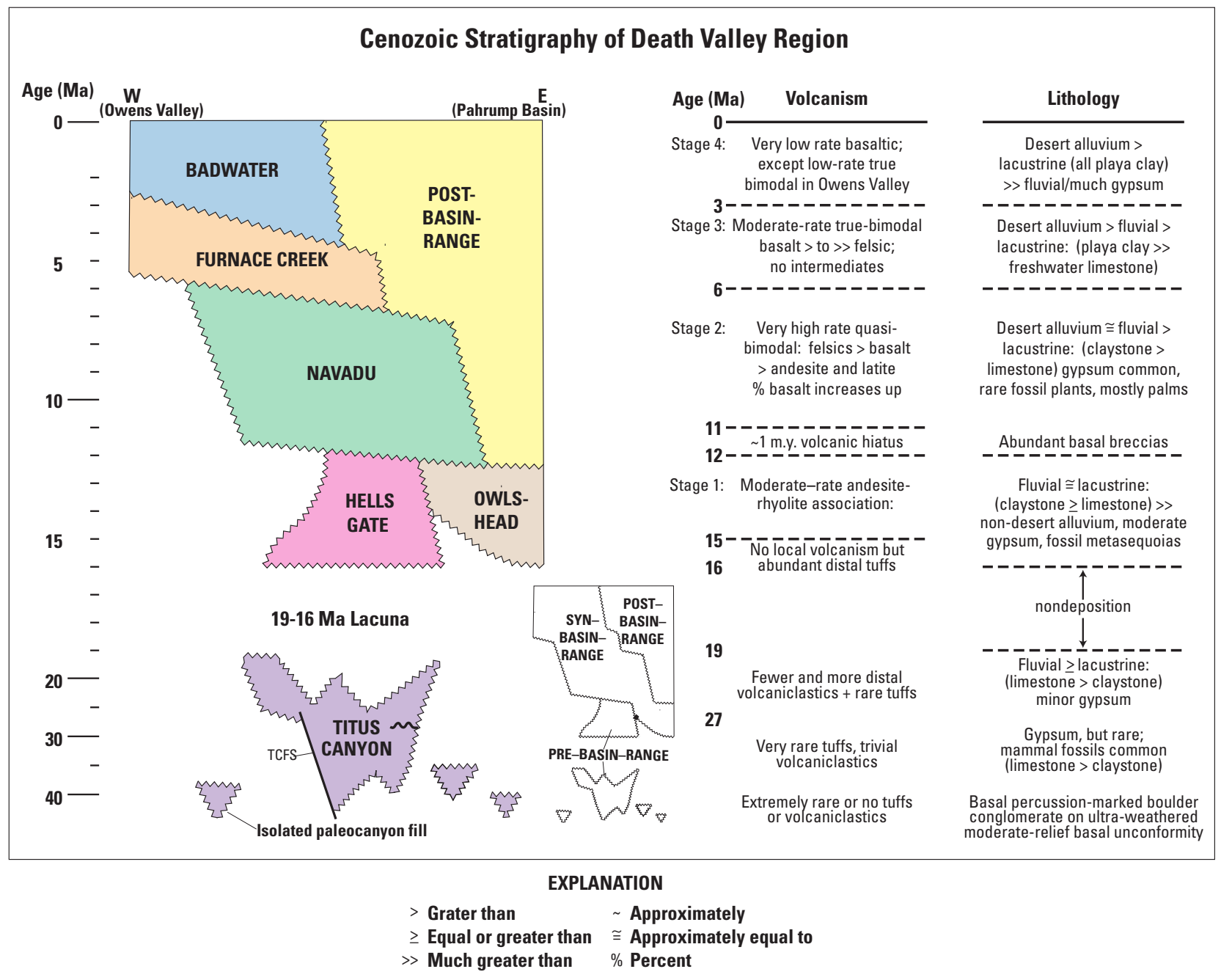

Figure 4. East-west and chronologic schematic diagram depicting the Cenozoic stratigraphy of the Death Valley region, showing the seven tectono-stratigraphic assemblages. Inset map (bottom, center) shows how these assemblages compose the pre-basin-range, syn-basin-range, and post-basin-range sequences. Two columns on the right summarize major volcanic and lithologic changes that occurred during deposition of Cenozoic strata. Within the Titus Canyon assemblage, the Titus Canyon fault system (TCFS) is the boundary between the Titus Canyon and Ubehebe basins.

the most conspicuous sediments in the Titus Canyon assemblage are tuffaceous siltstones that evidently were derived from central Nevada - from the north. A similar corridor of northerly provenance is found in the Hells Gate assemblage, but it is shifted westward into the area immediately downthrown on the Raven Canyon fault (RCF, figs. 6 and 7).

\section{Titus Canyon Assemblage}

The Titus Canyon assemblage includes the Titus Canyon and Ubehebe Formations of the Grapevine and Cottonwood Mountains, respectively (GM and CM; fig. 5; Reynolds, 1969; Snow and Lux, 1999), the rocks of Winapi Wash in Rock Valley and vicinity (RV; J. Yount and D. O'Leary, USGS, oral commun., 1995), and the Amargosa Valley Formation of the southern Funeral Mountains (SFM; fig. 5; Cemen and others,
1999). The basal strata of the Titus Canyon assemblage are locally as old as late Eocene and they overlie late Paleozoic through Neoproterozoic sedimentary units on a regional unconformity. During the initial deposition of this assemblage, the Death Valley region probably was part of the eastern flank of a broad, deeply eroded Mesozoic mountain range, with its crest near the current eastern front of the Sierra Nevada.

Snow and Lux (see their fig. 12; 1999) interpreted the Titus Canyon and Ubehebe Formations as representing two sequential cycles of sedimentation separated by a subtle unconformity that formed at a date they estimated at $\approx 25 \mathrm{Ma}$. In their model, the fill of the Ubehebe Basin is the younger Ubehebe Formation alone and that of the Titus Canyon Basin is the two formations stacked. The $\approx 25 \mathrm{Ma}$ stratigraphic boundary they propose is not included in the tectono-stratigraphy (fig. 4) because there is only a single locale, in the central 


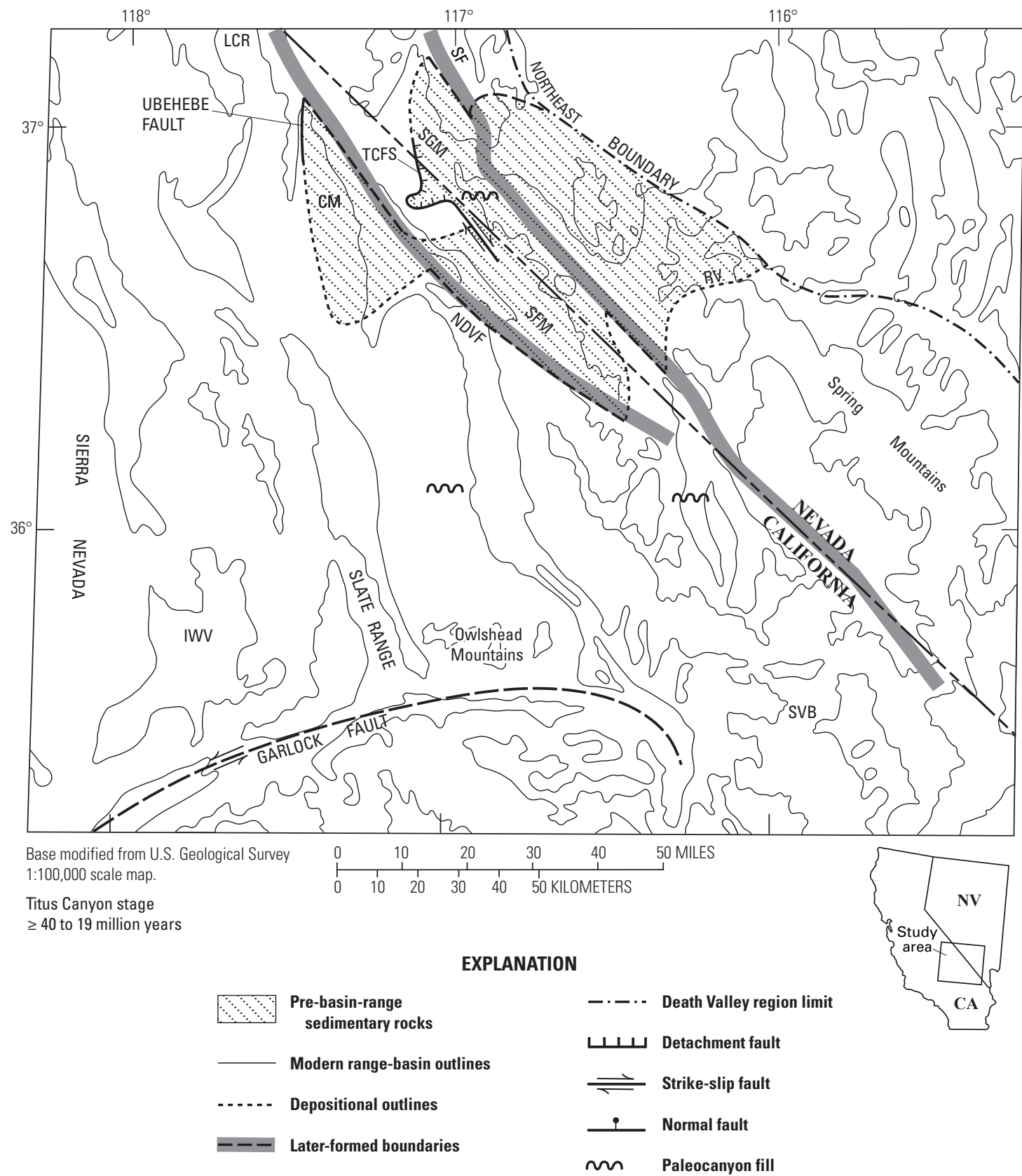

Figure 5. Present-day distribution of the $\geq 40$-to- $\approx 19-$ Ma Titus Canyon assemblage, showing postdepositional boundaries (internal and external) resulting from offsets across the northern Death Valley fault (NDVF) and the Stateline fault system (SF)—offsets which occurred primarily after $\approx 12 \mathrm{Ma}$. The only faults known to be active during deposition of the Titus Canyon Assemblage are the westernmost Fall Canyon segment of the Titus Canyon fault system (TCFS); and the Ubehebe fault, at the northwest limit of the Cottonwood Mountains (CM). Locations of paleocanyon fills of percussion-marked boulder conglomerates are shown with squiggly symbols; similar isolated pre-basin-range conglomerates have been reported, without exact locations, in the Last Chance Range (LCR), the Slate Range, the Owlshead Mountains, and the Shadow Valley Basin (SVB). Physiographic features shown are the southern Grapevine and southern Funeral Mountains (SGM and SFM), Indian Wells Valley (IWV), and Rock Valley (RV). 
Funeral Mountains (at $\approx 116^{\circ} 45^{\prime}$ and $\approx 36^{\circ} 37^{\prime}$ ) where this unconformity is straightforward (C. Fridrich, unpub. mapping, about 2000). It closely underlies a tuff that this study identifies as the $\approx 27$ Ma Monotony Tuff, based on its petrographic characteristics; hence, $\approx 28 \mathrm{Ma}$ is a better estimate of its age. This unconformity may well be present on a widespread basis but, if so, it is obscured in most locales by poor exposure or poor development of paleohorizontal indicators. Thus, it is not a regionally traceable stratigraphic boundary and, although its position is marked (fig. 4), it is not a recognized boundary in our stratigraphy. Nonetheless, it is the only known unconformity that formed in the $\geq 40$ to $\approx 19$ Ma interval, and thus may have regional tectonic significance, as discussed below.

The major known active structure of the Titus Canyon tectonic stage is the Fall Canyon fault (Reynolds, 1969). This fault is the southwesternmost strand of the Titus Canyon fault system (TCFS; fig. 5), a complex array of related obliqueslip faults exposed in the northeastern flanks of the southern Grapevine and northern Funeral Mountains. The thickness of the Titus Canyon assemblage, and the age of the strata at its base increase greatly northeastward across the Fall Canyon fault (Snow and Lux, 1999), indicating that it was active between $\geq 40$ to $\approx 19 \mathrm{Ma}$. Wedges of subangular colluvial boulder conglomerates and rock-avalanche breccias in basal Titus Canyon beds of the hangingwall block coarsen and thicken toward the fault and were derived from the footwall.

The Fall Canyon fault has steep dips at structurally shallow levels, but abruptly becomes subhorizontal at depth (Reynolds, 1969; Fridrich, unpub. mapping, 1995-2001). This fault is spectacularly well exposed, such that this unusual form is unequivocally that of a single fault. This fault geometry and low-angle fault striae indicate greater strike-slip than dip-slip offset. The upper plate of the Fall Canyon fault is cut by numerous closely spaced oblique-slip faults that terminate downward into the fault; thus it is an example of a "detachment fault," but not the type associated with metamorphic core complexes. Rather, it is a transtensional detachment structure as described by Hardyman and Oldow (1991) in the northern half of the Walker Lane belt.

The Titus Canyon fault system was the bounding structure of the pre-basin-range Titus Canyon Basin (palinspastically restored in fig. 7). Many of the component faults of this fault system remained active into the time of basin-range tectonism, and activity did not totally cease until $\approx 10 \mathrm{Ma}$ (Niemi, 2002). The partly subhorizontal Fall Canyon strand of the Titus Canyon fault system is the only strand that was active only during the $\geq 40$ to $\approx 19$ Ma Titus Canyon interval. Its major significance is that it proves that the dextral transtensional regime of the Death Valley region dates back to the late Eocene ( $\geq 40 \mathrm{Ma})$.

Snow and White (1990) documented another fault system that was active between $\approx 30$ and $\approx 19 \mathrm{Ma}$ - the Ubehebe fault, in the northern Cottonwood Mountains (CM; fig. 5), which is the bounding fault of the Ubehebe Basin. The remnants of the Ubehebe Basin are found to the west and south of those of the Titus Canyon Basin (fig. 5), but when post- $\approx 12$ Ma strike-slip deformation is accounted for, this basin was located mainly to the south and was upthrown relative to, and shallower than the Titus Canyon Basin (fig. 7).

The Titus Canyon Basin extends from near the California-Nevada border northeastward at least to the northeastern boundary of the Death Valley region (figs. 5, 6, and 7). The Ubehebe Basin lies southwest of the state line. Where present, the Titus Canyon fault system separates the two basins. Exposure of this fault system ends to the southeast, but the basin boundary appears to roughly follow the state border. The pre- $\approx 19$ Ma strata in the southern Funeral Mountains (SFM; fig. 5), resemble the Ubehebe Formation, whereas coeval strata exposed to the northeast of the Funeral Mountains more closely match the Titus Canyon Formation. Coeval deposits are present northeast of the Death Valley region, in the southern part of the Northern Basin and Range block, but on existing maps (Longwell and others, 1965; Tshanz and Pampeyan, 1961) they are lumped with younger units; hence, their distribution and character are not well known.

No volcanism was occurring in the Death Valley region during the Titus Canyon tectonic stage. The oldest known tuff in the Titus Canyon assemblage has been dated at $34.3 \mathrm{Ma}$ (Saylor and Hodges, 1994). This tuff is found only in a single locale, it is distal in character and, below it, Titus Canyon strata contain little or no volcaniclastic material. The $27 \mathrm{Ma}$ Monotony Tuff and some minor associated units are thin but widespread in the middle of the assemblage. Several tuffs dating from $\approx 24$ to $19.5 \mathrm{Ma}$ are found in the upper part of the Titus Canyon section. These are also distal in character, but much less so than the older intercalated tuffs. Upsection increase in abundance of intercalated tuffs and volcaniclastic material reflects the progressive advance of active volcanism toward the region, from north and south, during the $\geq 40$ to $\approx 19 \mathrm{Ma}$ interval, as established by previous regional studies (Armstrong and others, 1969; McKee, 1971; Glazner and others, 2002).

The erosion surface at the base of the Titus Canyon assemblage has a well-developed and commonly thick lateritic weathering profile. Paleosols, where preserved, are pure, homogenous, microscopically grained, dark-red chemicalresidua soils with remnant clasts of the parent material only at the base. Paleocanyons and paleobluffs are locally found along the basal surface of the Titus Canyon assemblage. The basal strata are ubiquitously coarse grained. Fluvial boulder conglomerates fill local basal paleocanyons, in which large (maximum size typically $\geq 1 \mathrm{~m}$ ) boulders are well rounded and heavily percussion-marked, indicating a high-energy depositional environment. In the southern Grapevine Mountains (SGM; fig. 5), lacustrine beds, at a stratigraphic level slightly above a paleocanyon fill, contained a titanothere skull and other mammal bones estimated to be $\geq 40 \mathrm{Ma}$. Stock and Bode (1935), who first identified these mammal fossils, classified them as Oligocene. More recent correlation to well-dated fossils in Nebraska indicates they are late Eocene (oral commun., K.C. McKinney, USGS, Denver, 2002). 
Bedding in the Titus Canyon assemblage is nearly conformable to that of the underlying Paleozoic rocks, except where the underlying rocks were folded during late Paleozoic and Mesozoic contraction (Reynolds, 1969; Snow and Lux, 1999). The age of the basal strata varies from $\geq 40 \mathrm{Ma}$ to $\approx 25 \mathrm{Ma}$, which probably reflects protracted burial of relief on the basal surface. The section generally fines upward to lacustrine deposits of shale, freshwater limestone, and fine sandstone, typically capped by pebbly fluvial red volcaniclastic sandstones in the youngest (post- $\sim 25-\mathrm{Ma}$ ) part of the assemblage. The capping sandstones may represent a closing phase of deposition in which tectonically formed lakes were filled in and overlain by a widespread post-tectonic apron of fluvial deposits.

Source proximity increases upsection wherein the upper part typically contains Mesozoic granitoid and metavolcanic clasts only from sources in the Cottonwood Mountains and Panamint and Argus Ranges, whereas the lower part includes Mesozoic clasts from more distant sources, some perhaps from as far west as the Sierra Nevada. This change in provenance is accompanied by an upsection decrease in average clast size and rounding.

Climate change also played a role in the upsection lithologic changes found in the Titus Canyon assemblage. Gypsum is absent in the oldest part of the Titus Canyon assemblage, is only sparsely present below the stratigraphic level of the $\approx 27$ Ma Monotony Tuff, and then becomes progressively more abundant upsection. Fossils of medium to large mammals have been found only in the lower part of this assemblage (Stock and Bode, 1935), below the Monotony Tuff. Laterites, well developed at the beginning of the Titus Canyon tectonic stage, had largely disappeared by the end of this interval. All three of these changes suggest progressive, although probably not monotonic, drying of the climate during the $\geq 40$ to $\approx 19 \mathrm{Ma}$ interval.

In all but the southernmost part of the Death Valley region, the Titus Canyon assemblage overlies rocks that are nonmetamorphic or that are metamorphosed only to lower greenschist grade, at a maximum. Sedimentary clasts in this assemblage are also lower greenschist facies, at a maximum, excepting some far-traveled Mesozoic metavolcanic clasts from the far western part of the region. The significance of this is that it relates to the timing of uplift and exposure of the moderate- to high-grade metamorphic rocks of the core complexes in the central part of the region, as discussed below.

\section{$\approx 19$ to $\approx 16$ Ma Lacuna}

The Titus Canyon and Hells Gate assemblages are everywhere separated by a contact that is at least a disconconformity. In most cases, this contact is a subtle angular unconformity across which there is an abrupt change in lithology, clast size and character of included volcaniclastic materials. The youngest tuff of Titus Canyon sections, locally found near or at the top, yields an age of 19.5 Ma (Cemen and others,
1999; Snow and Lux, 1999). A widespread tuff found near the base of many Hells Gate sections has yielded ages of 15.5 to 15.9 Ma (Snow and Lux, 1999). Thus, there was a region-wide depositional hiatus from $\approx 19$ to $\approx 16 \mathrm{Ma}$, and argon age determinations in this range are rare to nonexistent in the Death Valley region, although they are common in bordering regions.

In the $\approx 19$ to $\approx 16 \mathrm{Ma}$ interval, strong basin-range tectonism was occurring: (1) in the central part of the Walker Lane belt (starting at the northwest limit of fig. 2 and extending northwest; Weiss and others, 1993), (2) immediately to the northeast of the Las Vegas Valley shear zone (this study), (3) in the area immediately east of the Spring Mountains (Faulds and others, 1999), and (4) in the northern part of the Mojave, across the Garlock fault (Spencer, 1993; Glazner and others, 2002; Monastero and others, 2002; Andrew and others, 2010). Thus, although the Death Valley region was tectonically quiescent or nearly so in this interval, it was surrounded on all but the west side by areas of active basin-range tectonism. This provides a probable explanation for the $\approx 19$ to $\approx 16 \mathrm{Ma}$ lacuna. In this interval, the Death Valley region may have been a peninsula of only weakly extended rocks, that jutted out on the eastern edge of what is the Sierra Nevada block, and that stood high relative to actively subsiding basins in surrounding regions on all but the west side.

\section{Hells Gate Assemblage of the Hells Gate- Owlshead Tectonic Stage}

The pre-basin-range Hells Gate assemblage is coeval with the syn-basin-range Owlshead assemblage, to the southeast, reflecting the diachronous onset of basin-range tectonism in the Death Valley region (figs. 4, 5, and 7). The temporal equivalence is proven by extensive dating of volcanic interbeds in both assemblages. The sedimentary character of the two assemblages differs strongly, except that both were deposited under the same climatic conditions, as reflected, for example, in abundances of gypsum and freshwater limestone in lacustrine beds. Like the Titus Canyon assemblage, the sedimentary component of the Hells Gate assemblage is dominated by lacustrine and distal fluvial strata, in contrast to that of the Owlshead, which is dominated by coarse angular proximal deposits, like the other syn-basin-range assemblages.

The Hells Gate assemblage includes sedimentary rocks of the Panuga Formation of the Cottonwood Mountains (CM; Snow and Lux, 1999), the rocks of Pavits Spring in and around Rock Valley (RV; Hinrichs, 1968; plate 1), and the "green conglomerate" in the southern Grapevine Mountains (GM) and northern Funeral Mountains (fig. 6; Reynolds, 1969; 1974; Snow and Lux, 1999; Fridrich, unpub. mapping, 1995-2001; and see plate 1). It also includes the older (pre-12 $\mathrm{Ma}$ ) volcanic rocks in the southwestern part of the southwest Nevada volcanic field (SNVF; fig. 3), including the tuffs and lavas of the (12.8 to $12.5 \mathrm{Ma}$ ) Paintbrush and (13.5 to $13.1 \mathrm{Ma}$ ) Crater Flat Groups, the $\approx 14$ Ma Lithic Ridge Tuff and related underlying lavas (Sawyer and others, 1994; and see plate 1), 


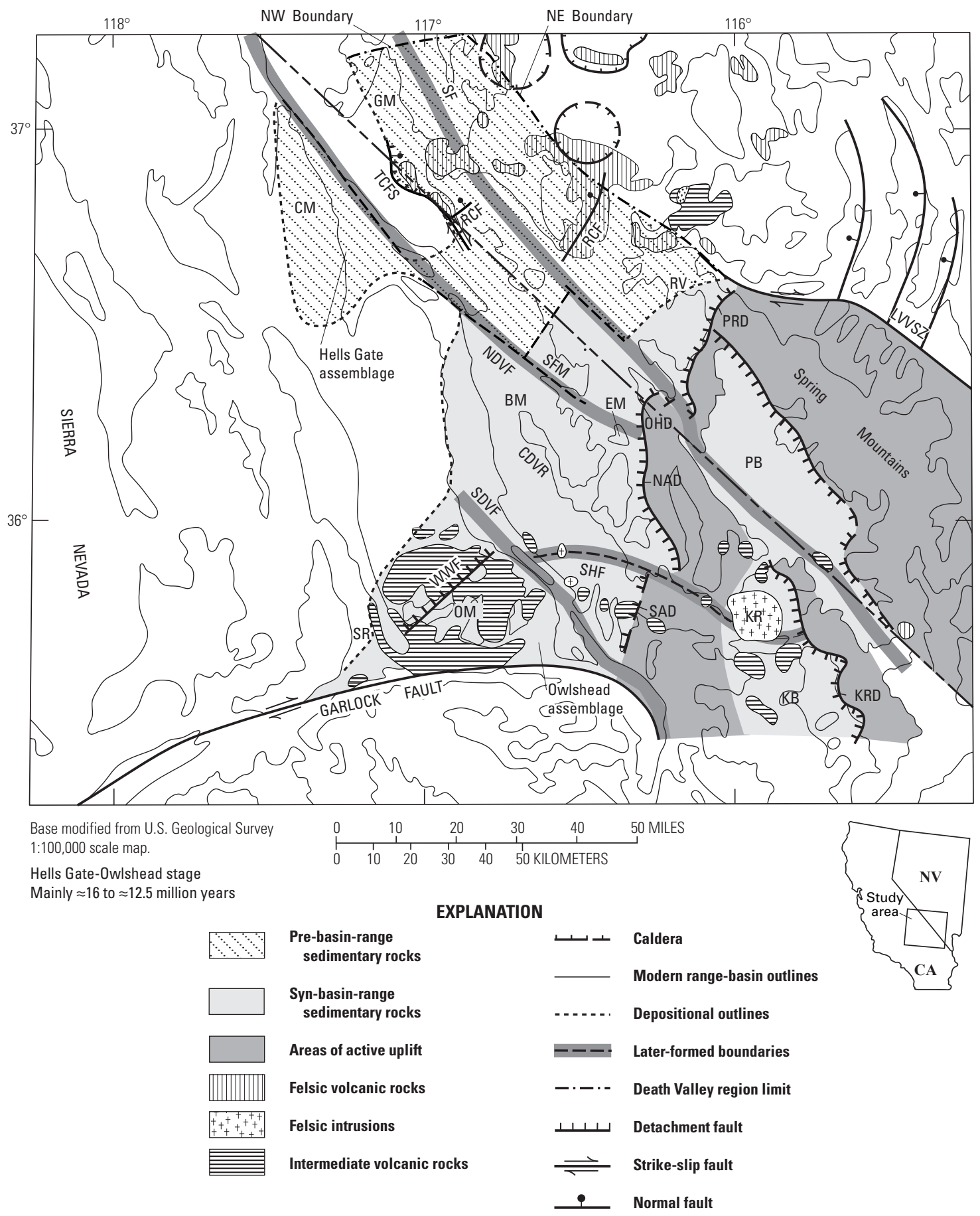

Figure 6. Present-day distributions of the largely coeval pre-basin-range Hells Gate assemblage and syn-basin-range Owlshead assemblage, along with the major faults known to be active during the Hells Gate-Owlshead tectonic stage. Also shown is the distribution of exposed volcanic rocks and intrusions. Later-formed boundaries resulted from post-depositional right-lateral offsets across the southern Death Valley fault (SDVF; $\approx 25$ to $50 \mathrm{~km}$ ), Sheephead fault (SHF; $\approx 10$ to $20 \mathrm{~km}$ ) northern Death Valley-Furnace Creek fault (NDVF; $\approx 50$ to $80 \mathrm{~km}$ ), and Stateline fault system (SF; $\approx 20$ to $30 \mathrm{~km}$ ). Major faults known to be active in the $\approx 16$ to $\approx 12 \mathrm{Ma}$ interval include the Titus Canyon fault system (TCFS; excluding the Fall Canyon fault segment; see fig. 5), the two segments of the Raven Canyon fault system (RCF), the Las Vegas Valley shear zone (LVVSZ); the Point of Rocks detachment fault (PRD), the Opera House detachment fault (OHD); the north and south segments of Amargosa detachment fault (NAD and SAD); and the Kingston Peak detachment fault (KPD), master fault of the $\approx 15$ to $\approx 12 \mathrm{Ma}$ Kingston Basin. The master fault of the Pahrump Basin (PB) is unnamed, and is an inferred detachment fault. The Wingate Wash fault (WWF), in the Owlshead Mountains (OM), is moderate- to low-angle and strongly listric, but is not considered a detachment fault by all workers. The volcanic rocks of the north part of this figure lie in the southern half of the southwest Nevada volcanic field (SNVF), shown in figure 3. 
and several older, volcanic and volcaniclastic units dating from $\approx 15$ to $\approx 14.1 \mathrm{Ma}$, which have been called the Leadfield Formation by Snow and Lux (1999).

The Titus Canyon and Raven Canyon fault systems (TCFS and RCF; fig. 6) were active during the Hells GateOwlshead tectonic stage as shown by strong stratigraphic thickening of the Hells Gate assemblage across all but one of the component faults of both systems. That one component fault is the Fall Canyon strand of the Titus Canyon fault system, discussed above. The Raven Canyon fault system consists of two strands striking northeast and dipping northwest. Both are normal faults with a lesser component of left-lateral offset. The Raven Canyon fault system was active between $\approx 16$ and $\approx 13 \mathrm{Ma}$, based on the observed pattern of stratigraphic growth across it. It may have been active earlier, in the Titus Canyon tectonic stage; however, existing data are not definitive.

Volcanism in the Death Valley region began during the Hells Gate-Owlshead tectonic stage. Separate volcanic fields were active within the domains of Hells Gate and Owlshead deposition, both of which can be described as andesite-rhyolite associations. The dominantly andesitic Owlshead volcanic field in southern part of the Owlshead domain (fig. 6), formed between $\approx 14.5$ to $\approx 12.1 \mathrm{Ma}$. Synchronous volcanism of the early (15.2 to $12.5 \mathrm{Ma}$ ) southwest Nevada volcanic field (SNVF; fig. 3; Sawyer and others, 1994) was dominated by eruption of rhyolite tuffs and lesser andesites in the northeastern and central parts of the Hells Gate domain (fig. 6).

The central caldera complex of the southwest Nevada volcanic field (fig. 6) roughly straddles the boundary between the Death Valley region and the Northern Basin and Range block. During the Hells Gate-Owlshead tectonic stage, the northeastern part of this volcanic field, outside the Death Valley region, was mixed in character, and included, most notably, a basalt-trachyte-comendite association, reflecting the differing tectonic setting to the north, outside of the region. Only minor sedimentary strata are interbedded with the pre- $\approx 12$ Ma volcanic units within the southwest Nevada volcanic field. The "green conglomerate" of Reynolds (1969; 1974) underlies Hells Gate-age eruptive units of this volcanic field near its southwestern limit, but also extends beyond the volcanic field southeast of there.

The Hells Gate assemblage is up to ten times thicker in the Titus Canyon Basin than in the Ubehebe Basin. Whereas the base-age of the Hells Gate assemblage is uniform throughout its range, Hells Gate strata younger than $\approx 15 \mathrm{Ma}$ are absent in the southwestern part of the Ubehebe Basin, the area that is the Cottonwood Mountains (CM, figs. 6 and 7). The eruptive units of the southwest Nevada volcanic field are largely contained within the Titus Canyon Basin, suggesting that the Titus Canyon fault system formed a topographic barrier. Only small volumes of the largest ash-flow eruptive units overtopped this barrier to be deposited in the Ubehebe Basin.

The character of Hells Gate sedimentary rocks differs strongly between the Titus Canyon and Ubehebe Basins, despite that they were directly adjacent. Those of the Ubehebe Basin are mainly pebbly fluvial red sandstones in which the sand was derived from mixed sources, including Tertiary volcanic rocks, Neoproterozoic and Paleozoic quartzites and chert, and Mesozoic granitoids. The pebbles are derived from the same sources; however, Tertiary volcaniclastic material is mainly in the sand-size fraction. These strata are similar to the redbeds that commonly form the uppermost part of the Titus Canyon assemblage, but contain different volcanic interbeds. In contrast, the sedimentary rocks interbedded with the Hells Gate-age volcanic units of the Titus Canyon Basin are mainly yellowish-tan, fine-grained, and typically so tuffaceous that they verge on being waterlain tuffs regardless of depositional environment. Hells Gate strata of the Titus Canyon Basin that are beyond the limit of the southwest Nevada volcanic field, or that predate the onset of local volcanism (at $\approx 15 \mathrm{Ma}$; for example, the "green conglomerate") are similar in lithologic character to those of the Ubehebe Basin.

Fossil wood is not uncommon in the Hells Gate assemblage, and in $\approx 14$ Ma strata (S. Minor, USGS, Denver, oral commun., 2000) in one locale in the northwestern part of the Death Valley region, it has been identified as metasequoia (Walker, 1936), indicating that the region was not a desert in this interval.

\section{Syn-Basin and Range Sequence}

Active basin-range tectonism migrated westward across the Death Valley region in four stages, each recorded by its own assemblage of basin-fill strata (fig. 4). Cenozoic sections of the region typically consist of more than one of these assemblages, resulting in stacked deposits from different tectonic stages. Most commonly, provenance is abruptly more proximal upsection across assemblage boundaries, reflecting progressive tectonic fragmentation of drainage basins during basin-range tectonism.

Cenozoic basin fills in the eastern part of the Death Valley region consists mainly of the Owlshead and Navadu assemblages, locally capped by the Furnace Creek assemblage. In contrast, basin fills in the western part of the region consist mainly of the Furnace Creek and Badwater assemblages, locally underlain by the Navadu assemblage (figs. 6, 8, 9, and 10). Throughout the region, the only area with all four assemblages is the central Death Valley rhombochasm (CDVR; fig. 2).

Clasts of proximal moderate- to high-grade metamorphic rocks derived from local core complexes first appear in the stratigraphic record in the syn-basin-range sequence, and they are almost entirely restricted to near-source depocenters. These clasts record the unroofing of adjacent detachment fault footwalls. The timing of their appearance in the stratigraphic record agrees well with the timing of tectonic denudation, uplift and exposure that has been interpreted from radiometric uplift ages for the adjacent core complexes (Holm and others, 1992; Hoisch and Simpson, 1993; Applegate and Hodges, 1995; Hoisch and others, 1997). 


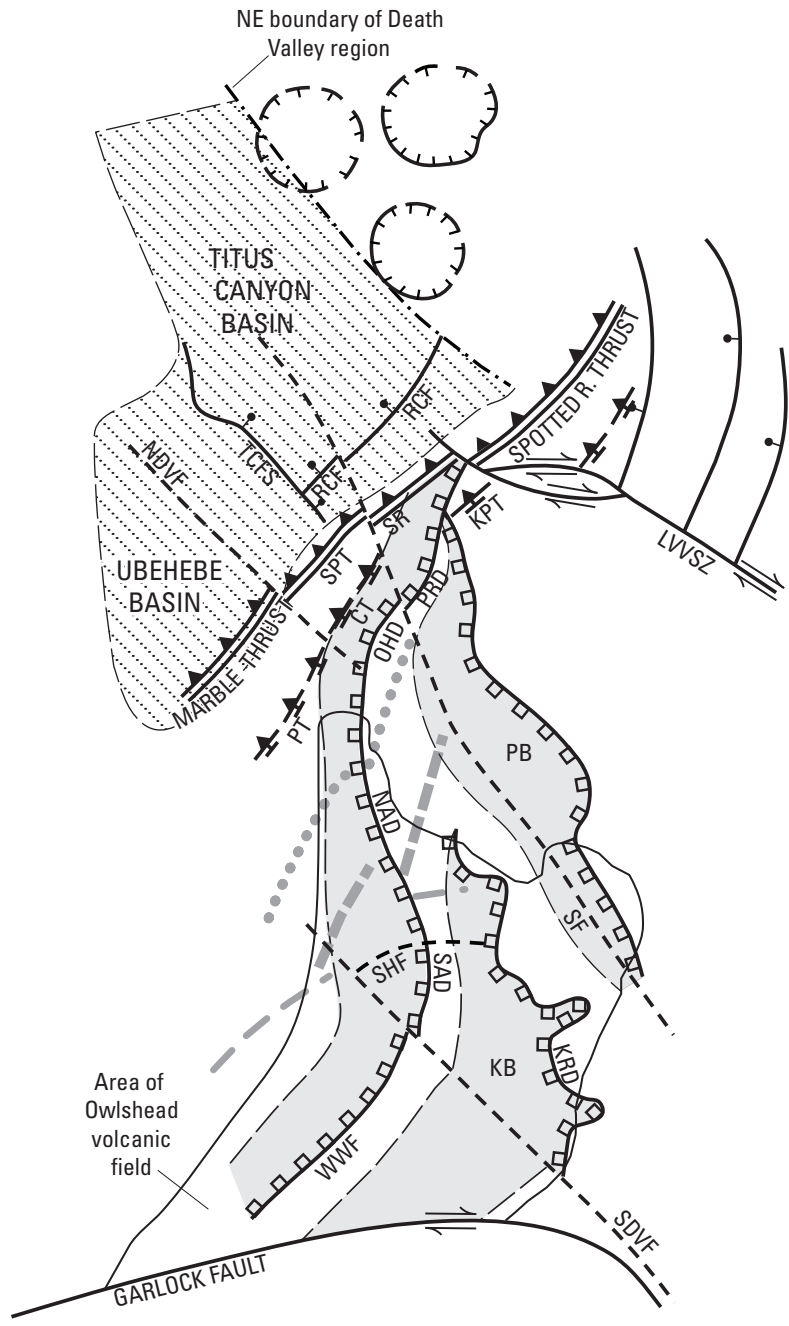

\section{EXPLANATION}

Syn-basin-range sedimentary rocks (Owlshead assemblage)

Pre-basin-range sedimentary rocks (Hells Gate assemblage)

$\perp+$ Caldera

Depositional outlines

$\rightleftharpoons \quad$ Strike-slip fault (active)

- - - - Strike-slip fault (slip restored)

חمــ Detachment fault

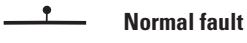

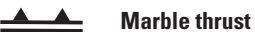

소소 Lemoigne thrust

600-meter Stirling Quartzite (Zs) isopach

150-meter Zabriskie Quartzite $(€ z)$ isopach

$\longrightarrow$ Noonday Dolomite pinchout

Figure 7. Structural pattern of the Hells Gate-Owlshead tectonic stage palinspastically restored to correct for post- $\approx 12-$ Ma extension, and for strike-slip offsets across the southern Death Valley fault (SDVF), Sheephead fault (SHF), northern Death Valley fault (NDVF), and Stateline fault system (SF). Other Cenozoic features shown include the Titus Canyon fault system (TCFS), the two realigned segments of the Raven Canyon fault system (RCF), the Point of Rocks detachment fault (PRD), the Opera House detachment fault (OHD); the north and south segments of Amargosa detachment fault (NAD and SAD); and the Kingston Range detachment fault (KRD). Palinspastically restored features include the Marble and LeMoigne Thrust faults, isopachs of the Stirling Quartzite (Zs) and Zabriskie Quartzite (€z), the pinchout of the Noonday Dolomite, and the correlated segments of the Schwaub Peak Thrust = SPT; Specter Range Thrust $=$ SR, Panamint Thrust $=$ PT; Cleary Thrust $=$ CT; Kwichup Peak Thrust $=$ KPT. Also shown are the Las Vegas Valley shear zone (LVVSZ) and the Garlock fault, which were active in the Hells Gate-Owlshead tectonic stage. Some features are not corrected for post- $\approx 12$ Ma strain. For example, the Wingate Wash fault (WWF) of the Owlshead Mountains is probably rotated at least $30^{\circ}$ clockwise, because of post- $\approx 12-\mathrm{Ma}$ oroflexural bending adjacent to the Garlock fault. Likewise, dextral strike-slip strain has probably rotated the Garlock fault clockwise since $\approx 12 \mathrm{Ma}$, especially the easternmost part. Also shown are the Pahrump and Kingston Basins (PB and KB). 


\section{Owlshead Assemblage of the Hells Gate- Owlshead Tectonic Stage}

The Owlshead assemblage is found throughout the eastern and central parts of the Death Valley region (fig. 6), and records the first stage of basin-range extension. In the easternmost part, it includes nearly all of the syntectonic strata found around the perimeter of the Pahrump Basin (PB) and in the Black Butte pressure ridge (BB) in southern part of this basin. It also includes Member 1 and most of the "pre-basinal" rocks (plate 1; Friedmann, 1999; Friedmann and others,1996) of the Kingston Basin (KB; fig. 6), a Hells Gate-Owlshead stage basin that covered the current areas of the Shadow Valley Basin and the Kingston Range. Paleocanyon fills of distally (and easterly) derived conglomerate are locally present at the base of the "pre-basinal" section in the Shadow Valley basin, and these strata alone are pre-basin-range. The remaining "prebasinal" strata of the Kingston Basin locally contain small ( $\approx 10 \mathrm{~m}$ diameter) ballistic masses of rock-avalanche breccia derived from the ranges that surround the basin; thus, these strata are actually syn-basin-range, and they are part of the Owlshead assemblage.

In the northwestern part of its range, the Owlshead assemblage includes all of the pre- $\approx 12$ Ma strata of the central Death Valley rhombochasm. In the northern part of the rhombochasm, this consists of the lower (pre- $\approx 12 \mathrm{Ma}$ ) part of the Eagle Mountain Formation at Eagle Mountain (EM, fig. 6; Niemi and others, 2001) and the rocks of Billie Mine (BM; fig. 6; Cemen, 1983; Wright and others, 1999). In the southern part of the rhombochasm, it consists of pre- $\approx 12 \mathrm{Ma}$ andesites and interbedded sedimentary rocks (for example, the andesite of Ashford Mill at Virgin Canyon; VC; fig. 6 and plate 1; Snow and Lux, 1999; Wright and Troxel, 1984). In the western part of the rhombochasm, it consists of the pre- $\approx 12$ Ma rocks of the Trail Canyon sequence (on the eastern flank of the Panamint Range; McKenna and Hodges, 1990). North of the rhombochasm, it includes the Kelley's Well Limestone and overlying Bat Mountain Formation of the southern Funeral Mountains (SFM, fig. 6; plate 1; Cemen and others, 1999).

In the southwestern part of its range, the Owlshead assemblage (fig. 6) includes all of the syntectonic strata of the northern and central Owlshead Mountains (OM; fig. 6; Wagner and others, 1988; Luckow and others, 2005). Correlative rocks are found in the southern parts of the Owlshead Mountains and adjacent Slate Range (SR; fig. 6); however, in these areas, the Owlshead strata are unconformably overlain by post $-\approx 12$ $\mathrm{Ma}$ (both Navadu and Furnace Creek assemblage) syntectonic strata.

Owlshead strata overlie pre-Tertiary rocks, except locally where paleocanyon fills of Titus Canyon strata are present under them, as discussed above. Unlike the Hells Gate assemblage, the Owlshead deposits are strongly disconformable with everything they overlie. The base of the Owlshead assemblage is perhaps as old as $\approx 16 \mathrm{Ma}$ in the Pahrump Basin, younging westward to a minimum of $\approx 14$ to $\approx 14.5 \mathrm{Ma}$ in the Owlshead Mountains (Luckow and others, 2005; and see plate 1) and in the central Death Valley rhombochasm (Wright and others, 1991). Thus, the onset of basin-range extension began in the easternmost part of the region and migrated westward with time, within the Hells Gate-Owlshead tectonic stage.

Basins that accumulated Owlshead assemblage fill include (fig. 6): (1) the Pahrump Basin (PB), (2) the Kingston Basin (KB) - the supradetachment basin of the Kingston Range detachment fault (KRF) in the form it had from $\approx 15$ to $\approx 12.5 \mathrm{Ma}$ (figs. 6 and 7), (3) the half-graben downthrown on the Wingate Wash fault (WWF), and adjacent smaller basin(s) in the central and southern Owlshead Mountains (OM); and (4) the supradetachment basins of the Amargosa (north and south segments; NAD and SAD), Opera House (OHD), and Point of Rocks detachment faults (PRD; fig. 6). If the master faults of all of these basins are viewed as a regional system of faults, the overall pattern is one of fanning open to the south (fig. 6). This fanning pattern is reflected not only in the overall geometry, but also in the fact that the combined throws of the master faults of these basins diminishes progressively to the north. The northward termination of this fan-like arrangement of faults is near the apparent northwest terminus of the Las Vegas Valley shear zone (LVVSZ; figs. 3 and 6). The abundance of rock-avalanche breccias in the Owlshead assemblage increases to the south across the region, which is consistent with southward-increasing extension.

The geometry of the Owlshead-stage basins has been strongly modified by post- $\approx 12 \mathrm{Ma}$ extension and strike-slip offset. Palinspastic restoration for that later deformation simplifies the fan-like pattern of faulting (compare figs. 6 and 7). When offset segments of Mesozoic thrust faults and other pre-Cenozoic piercing points are rejoined across the major strike-slip faults (as was done to create fig. 7), the (1) Point of Rocks and Opera House detachment faults (PRD and OHD), the (2 and 3) northern and southern parts of the Amargosa detachment fault (NAD and SAD), and the (4) Wingate Wash fault (WWF; figs. 6 and 7) all become roughly aligned across the northern Death Valley (NDVF), Stateline (SF), Sheephead (SHF), and southern Death Valley (SDVF; figs. 6 and 7) strike-slip faults. Whereas most of the offset across these major strike-slip faults postdates $\approx 12 \mathrm{Ma}$, these faults may have existed as structural discontinuities before then (Cemen and others, 1999). Moreover, the northern and southern Death Valley faults were demonstrably active in the Hells Gate-Owlshead stage, as discussed above.

Several large low-angle structures are exposed along the deeply eroded northeastern scarp of the Pahrump Basin against the Spring Mountains, and these have been interpreted by some workers as erosional fragments of a basin-bounding low-angle normal (detachment) fault (Wernicke and others, 1989). However, in recent geologic mapping (Page and others, 2005), these structures have been interpreted as landslide slip surfaces at the bases of giant Toreva blocks; hence, it is unclear if Pahrump Valley is a supradetachment basin or not. In contrast, all of the other basins with Owlshead assemblage basin fill are clearly supradetachment basins, with the possible exception of the Wingate wash basin. The Wingate Wash fault 
(WWF; fig. 6) dips $\approx 40^{\circ}$ at the surface, and seismic data have been interpreted as indicating that it rapidly flattens at depth (Wagner, 1988); hence, it could be interpreted as a detachment fault, but has not been interpreted that way by most workers.

The eruptive units of the Owlshead volcanic field have yielded argon dates ranging from 14.5 to $12.1 \mathrm{Ma}$ (Wagner, 1988; Fowler and Calzia, 1999; Friedmann, 1999; R. Fleck, USGS, unpub. data, about 1985) and currently occupy an east-west belt across the southernmost part of the Death Valley region. When palinspastically restored, this volcanic field has no obvious orientation (fig. 7). Compositions range from basalt to rhyolite, but andesitic lavas and related, mostly laharic breccias predominate. These volcanic rocks typically are interbedded with sedimentary strata, most conspicuously rock-avalanche megabreccias. To the north, in that part of the Owlshead domain that incurred lesser extension and that lies beyond the volcanic field, sedimentary strata predominate, breccias are sparse, and volcanic rocks are limited to interbeds of distal tuffs.

As well as breccias, the sedimentary strata of the Owlshead assemblage include fluvial sandstones and conglomerates, lacustrine claystones and freshwater limestones, and alluvial conglomerates. The sandstones and the sandy matrices of the conglomerates typically are volcaniclastic. The pre- $\approx 12 \mathrm{Ma}$ alluvial conglomerates of the Owlshead assemblage are notable in that they appear to have been deposited in a significantly wetter climate than the post-12 Ma alluvial conglomerates of the Death Valley region, which are typical desert alluvium. In the pre-12 Ma alluvial deposits, clasts are more rounded, there is a higher proportion of matrix, and the matrices are rich in sticky (probably kaolinitic) clays like those that form in the soils of non-arid climates.

\section{The $\approx 12.5$ to $\approx 11.5$ Ma Tectonic Reorganization}

During the $\approx 12.5$ to $\approx 11.5$ Ma tectonic reorganization, the locus of basin-range tectonism shifted westward from being centered in the eastern part of the Death Valley region to being centered in the central part (figs. 4, 6 and 8). The new belt of basin-range extension, of the Navadu tectonic stage, overlapped that of the Hells Gate-Owlshead stage (compare figs. 6 and 8). Thus, some existing basins were abandoned in the wake of the abrupt westward migration, others remained active - in modified form - through the tectonic reorganization, and several new basins formed westward of the pre- $\approx 12 \mathrm{Ma}$ belt of basin-range tectonism of the Hells Gate-Owlshead stage.

Basin-range extension ceased at $\approx 12 \mathrm{Ma}$ in the northern and central parts of the Owlshead Mountains (OM) and in all but the westernmost part of the Pahrump Basin (PB; compare figs. 6 and 8). Subsequently, these abandoned basins became sites of post-basin-range deposition. Additionally, the north half of the Kingston Basin was uplifted near the end of the Owlshead tectonic stage, at least partly because of emplacement of the large $\approx 12.5$ Ma granite at Kingston Peak pluton, which may have "pinned" the northern part of the Kingston Range detachment fault (Davis and others, 1993; KRD; fig. 6). Subsequent extension and deposition in the area of the Kingston Range was minimal (compare figs. 6 and 8), but transtensional strain along northeast-trending oblique-slip faults did occur in this area during the ensuing Navadu tectonic stage. The part of the Kingston Range detachment fault that lies south of the Kingston Peak pluton continued to be active after $\approx 12 \mathrm{Ma}$, and the second generation (Navadu-stage) supradetachment basin over the southern part of this fault is known as the Shadow Valley Basin (SVB; fig. 8; Friedmann, 1999).

In much of the Shadow Valley Basin, the unconformity separating the Owlshead and Navadu assemblages is directly overlain by alluvial conglomerates containing a late tuff of the Owlshead volcanic field dated at $12.5 \mathrm{Ma}\left({ }^{40} \mathrm{Ar}{ }^{39} \mathrm{Ar}\right.$, sanidine; Dan Miggins, USGS, unpub. data, about 2005) at or near the base. In the southern part of the Cottonwood Mountains, in the western part of the region, the correlative unconformity — between the Hells Gate and Navadu assemblages, in this case - is directly overlain by ash-fall tuffs (Snow and Lux, 1999) having similar argon ages and petrographic character as the major tuffs of the Timber Mountain Group (dated at 11.6 and 11.45 Ma; Sawyer and others, 1994). Thus, the diachronous unconformity that records this tectonic reorganization formed over an interval of about 1 million years - between $\approx 12.5$ and $\approx 11.5 \mathrm{Ma}$.

The local presence of a late tuff of the Owlshead tectonic stage in the basal strata of the Navadu assemblage, discussed above, is one of only two such instances. Because of the diachronous nature of the boundaries between the four syn-basin-range assemblages, it was possible for a volcanic unit to be erupted within the depositional area of one assemblage and to flow or fall distally into the depositional area of another assemblage during a tectonic reorganization. The other example of this, as discussed below, involves the $\approx 3.2 \mathrm{Ma}$ tuff of Mesquite springs, which is a Furnace Creek unit, but is variously found in the uppermost part of the Furnace Creek assemblage or the basalmost part of the Badwater assemblage. In all other cases we know of, the volcanic rocks of each assemblage are distinct, and are key to discriminating them.

\section{Navadu Assemblage and Tectonic Stage}

The Navadu assemblage includes the Navadu Formation of the Cottonwood Mountains (the fill of the Navadu Basin (NB) - the supradetachment basin of the Harrisburg fault (HD; fig. 8; Snow and Lux, 1999). In the central part of the central Death Valley rhombochasm (CDVR; fig. 8), the Navadu section consists of a sparsely exposed basal sedimentary section, overlain by a thick stack of volcanic rocks, including: the $\approx 11$ Sheephead Andesite, the $\approx 10.5$ Ma Rhodes Tuff, and the lavas and related tuffs of the $\approx 10$ to $\approx 7.5 \mathrm{Ma}$ Shoshone Volcanics (Wright and Troxel, 1984). Coming away from this volcanic locus (the central Death Valley volcanic field), correlative volcanic rocks thin and are increasingly interbedded with 


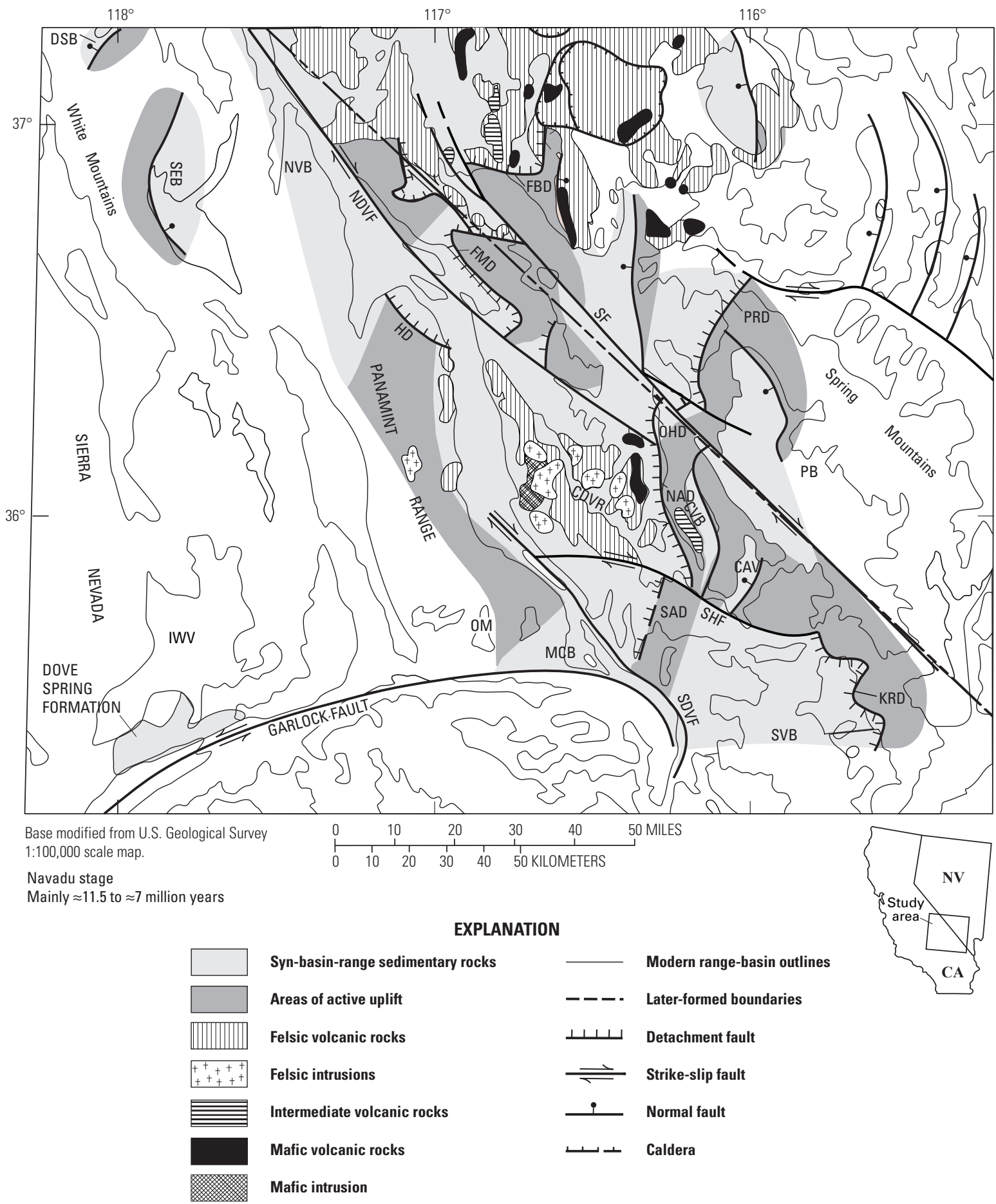

Figure 8. Present-day distribution of the $\approx 12$-to- $\approx 7-M a$ syn-basin-range Navadu assemblage, and the major faults known to be active during the Navadu tectonic stage. Also shown are: (1) the distribution of Navadu-age volcanic rocks and intrusions, and (2) the distribution of the Dove Spring Formation, at the south end of Indian Wells Valley (IWV). Navadu-stage basins include Deep Springs Basin (DSB); an unnamed basin encompassing the area that includes Saline Valley, Saline Range, and Eureka Valley (SEB); Navadu Basin (NVB); Military Canyon Basin (MCB), Shadow Valley Basin (SVB), and the central Death Valley rhombochasm (CDVR). Active faults of this stage include Fluorspar Canyon-Bullfrog Hills detachment fault (FBD), Funeral Mountains detachment fault (FMD), Harrisburg detachment fault (HD), Point of Rocks detachment fault (PRD), Opera House detachment fault (OHD), northern and southern segments of Amargosa detachment fault (NAD and SAD); and Kingston Peak detachment (KRD). 
sedimentary strata. In the northwestern part of the central Death Valley rhombochasm, this section of interbedded volcanic and sedimentary strata has been named the Artist Drive Formation (McAllister, 1970; Wright and others, 1999). The equivalent section along the eastern front of the Panamint Range, at the western margin of the central Death Valley rhombochasm (figs. 3 and 8), is the younger (post- $\approx 12 \mathrm{Ma}$ ) part of the Trail Canyon volcanic sequence (McKenna and Hodges, 1990).

East of Death Valley, in the Shadow Valley Basin (SVB; fig. 8), the Navadu assemblage consists of members II through IV of Friedmann (1999) in the east, and the "China Ranch beds" in the west (Wright and others, 1991; Prave and McMackin, 1999). South of Death Valley, on the southern flank of the Owlshead Mountains, the Navadu assemblage has been named the Military Canyon Formation, the fill of the Military Canyon Basin (MCB, fig. 8; Brady, 1986; Brady and Troxel, 1999). And to the north of Death Valley, equivalent sections consist largely of the younger (post- $\sim 12 \mathrm{Ma}$ ) volcanic rocks of the southwest Nevada volcanic field, including the $\approx 11.7$ to 11.4 Ma units of the Timber Mountain Group and numerous overlying eruptive units ranging in age from $\approx 11.3$ to $\approx 7 \mathrm{Ma}$ (for example, see plate 1, section I; Sawyer and others, 1994). In the southwest corner of the Death Valley region, in southern Indian Wells Valley (IWV; fig. 8), the Navadu assemblage is represented by the Dove Spring Formation, which has been dated at $\approx 13$ to $\approx 8 \mathrm{Ma}$ (K-Ar; Monastero and others, 2002).

The overall structural pattern of faulting and transtensional deformation in the Navadu tectonic stage is a radical departure from the tectonic pattern of the preceding Owlshead stage (compare figs. 6 and 8). The simple fanning pattern of basinrange extension in the Hells Gate-Owlshead tectonic stage was superceded by a complex structural pattern dominated by: (1) rapid slip along major strike-slip faults, including the Stateline, northern Death Valley, Sheephead, and southern Death Valley faults (SF, NDVF, SHF, and SDVF; compare figs. 6 and 8), and (2) large-scale tectonic denudation along detachment faults that strongly extended the structural blocks between the major strike-slip faults.

In the far western part of the Death Valley region, basinrange tectonism began at the beginning of the Navadu tectonic stage, but the major extension in this area came later, in the Furnace Creek and especially the Badwater tectonic stages (figs. 8, 9, and 10). Navadu-stage tectonism west of the Panamint Range appears to have been diffuse and poorly defined. Early Navadu assemblage $(\approx 12 \mathrm{Ma})$ sedimentary rocks of syntectonic character have been documented in the Deep Springs Basin (DSB; fig. 8) and in the Saline-Eureka Valleys area (SEB; fig. 8), to the southeast (Blakely and McKee, 1985; Reheis and Sawyer, 1997). Moreover, apatite fission-track and $\mathrm{U}-\mathrm{Th} / \mathrm{He}$ data show that rapid exhumation and eastward tilting of the White Mountains (northwest corner of figs. 2 and 8) began at $\approx 12 \mathrm{Ma}$ (Stockli and others, 2003), at the beginning of the Navadu tectonic stage. The last-mentioned evidence suggests that a more extensive pattern of Navadu-stage basin-range extension was present west of the Panamint Range than is shown (fig. 8); however, existing data do not permit the drawing of a more complete picture.

More than a dozen different basins actively subsided in the $\approx 12.5$ to $\approx 7 \mathrm{Ma}$ Navadu stage in the central part of the Death Valley region (see fig. 8). Basins formed by Owlsheadstage tectonism that continued to be active in the Navadu stage - in modified form - include: (1) the far western part of the Pahrump Basin (PB), (2) the Shadow Valley Basin (SVB), (3) the central Death Valley rhombochasm, which in this stage is called the Artist Drive Basin, and (4) the supradetachment basins of the Opera House (OHD) and Point of Rocks (PRD) detachment faults (fig. 8).

Several new basins formed at $\approx 12 \mathrm{Ma}$ to the north and northwest of the central Death Valley rhombochasm (CDVR; compare figs. 6 and 8) besides those discussed above. For example, three new detachment faults formed early in the Navadu tectonic stage: (1) the Fluorspar Canyon-Bullfrog Hills fault (FBD), (2) the Boundary Canyon-Keane Wonder fault (aka, Funeral Mountains fault; FMD), and (3) the Harrisburg (HD) fault. A Navadu-stage supradetachment basin formed over each of these faults. Navadu-stage basins that formed at roughly the same time $(\approx 12 \mathrm{Ma})$, and that were unrelated to detachment faulting include (from north to south): the Crater Flat Basin; (CFB; Fridrich, 1999; Fridrich and others, 1999); Chicago Valley Basin (CVB), California Valley Basin (CAV), and Military Canyon Basin (MCB; fig. 8).

The magnitude of extension and strike-slip strain of the Navadu tectonic stage was equal to, or greater than, that of the other three stages of basin-range tectonism combined. Partly, this reflects the longer interval of the Navadu stage (see fig. 4). More importantly, the rate of basin-range tectonism in the Death Valley region peaked in the Navadu interval.

As per the basin-range tectonism of the Hells Gate-Owlshead stage, there was a discernible pattern of slow, continuous monotonic evolution within the Navadu tectonic stage. Specifically, the locus of strongest syndepositional faulting and tilting slowly migrated westward within many individual basins during this stage, as documented in the Crater Flat Basin (Fridrich and others, 1999) and across the supradetachment basin of the Fluorspar Canyon-Bullfrog Hills fault (Fridrich, 1999). In the central Death Valley rhombochasm, Navadu strata in the east half of the basin show evidence of strong growth faulting and fanning of dips from $\approx 12$ to $\approx 10 \mathrm{Ma}$, followed by deposition lacking evident coeval deformation from $\approx 10$ to $\approx 7 \mathrm{Ma}$. In contrast, syndepositional faulting and tilting in the west half of basin, between $\approx 10$ and $\approx 7 \mathrm{Ma}$, was equal to, or greater than, that from $\approx 12$ to $\approx 10 \mathrm{Ma}$.

Volcanism associated with the Navadu tectonic stage was "quasi-bimodal" (fig. 4), meaning that it was comprised mainly of mafic and silicic magmas erupted with lesser volumes of andesites (figs. 4 and 8). By about $10 \mathrm{Ma}$, andesites had disappeared, and thus, late-stage Navadu volcanism was truly bimodal, and was dominated by felsic compositions.

Volcanism of the Navadu stage occurred mainly in two loci: the central Death Valley volcanic field, in the 
south-central part of the region, and in the (post- $\approx 12 \mathrm{Ma}$ ) southwest Nevada volcanic field, near the northern boundary of the Death Valley region. The magma eruption rate was significantly greater during the Navadu stage than in the Hells Gate-Owlshead stage, and a major hiatus separated the volcanic pulses associated with these two stages. In the southwest Nevada volcanic field, this hiatus extended from the end of the Paintbrush Group resurgent cauldron cycle, at $\approx 12.5 \mathrm{Ma}$, to the beginning of the Timber Mountain Group cycle, at $\approx 11.7$ Ma (Sawyer, 1994; Fridrich and others, 2007). In the southern part of the region, the hiatus separates the end of activity in the Owlshead volcanic field, at $\approx 12.1 \mathrm{Ma}$, and the beginning of activity in the central Death Valley volcanic field, at $\approx 11 \mathrm{Ma}$ (this study, unpub. data).

Throughout the region, this volcanic hiatus is recorded by deposition of a basal Navadu section that lacks juvenile volcanic strata. Notably, this section contains a greater abundance of rock-avalanche megabreccias and other coarse syntectonic deposits than any other part of the Cenozoic section, and typically has strongly fanning dips within it. These features are consistent with a hypothesis, proposed by Gans and Bohrson (1998), that this volcanic hiatus was a consequence of an exceptionally strong tectonic pulse that resulted in stagnation of magma at deep crustal levels.

Volcanic rocks dominate the Navadu section in several parts of the region, particularly the northern part, within a wide perimeter around the central caldera complex of the southwest Nevada volcanic field (fig. 8). They also dominate in the area of the central Death Valley volcanic field, which covered the whole central part of the central Death Valley rhombochasm, and extended east of there, across the Resting Spring Range and into the Chicago Valley Basin (CVB; fig. 8). The high rate of Navadu-stage volcanism, in combination with the fact that much of this volcanism was pyroclastic, resulted in the sedimentary rocks of the Navadu assemblage being exceptionally tuffaceous throughout the region, regardless of deposition environment.

The character of the sedimentary rocks of the Navadu assemblage is distinct in other ways from that of the preceding (pre- $\approx 12 \mathrm{Ma}$ ) assemblages. For example, alluvial conglomerates comprise $\leq 1$ percent of the pre-basin-range sequence and $\leq 5$ percent of the Owlshead assemblage; whereas roughly 20 percent of the sedimentary budget in the Navadu assemblage is alluvial. Like the modern alluvium of the Death Valley region, Navadu-stage alluvium shows only minor rounding of clasts and is largely clast supported. Instead of containing kaolinitic clays, the matrices of Navadu alluvium are typically sandy and where they are clayey, the clay is illitic, is probably derived from alteration of volcanic glass, and appears to be largely diagenetic rather than primary. Relative to Hells GateOwlshead strata, Navadu strata have much less freshwater limestone and more gypsum in lacustrine deposits, as well as a lower abundance of fossil wood. Moreover, in this study, only desert oasis species of petrified wood — mainly palms - were found in Navadu strata.
The abrupt change to drier-climate sediments at $\approx 12 \mathrm{Ma}$ may be related to the formation of a rain shadow caused by the uplift of the White-Inyo Mountains (Stockli and others, 2003). Stockli and others' radiometric uplift data may, thus, date the initial formation of the Sierra Nevada uplift. If so, this major uplift evidently had its eastern front at the western margin of Saline Valley in the Navadu stage. However, many workers have tried to date the initial uplift of the Sierra Nevada block, and the different lines of evidence that have been studied do not converge well (see a review by Phillips, 2009).

\section{The $\approx 6.5$ Ma Tectonic Reorganization}

During the tectonic reorganization between the Navadu and Furnace Creek stages, the belt of active basin-range tectonism in the Death Valley region abruptly shifted westward, for the second time (compare figs. 8 and 9). In the process, the supradetachment basins of all seven of the detachment faults of the Navadu tectonic stage were abandoned: Kingston Range (KRD), Fluorspar Canyon-Bullfrog Hills (FBD), Point of Rocks (PRD), Opera House (OHD), Funeral Mountains (FMD), Harrisburg (HD), and Amargosa (NAD and SAD faults as shown on figure 8 . The supradetachment basins of these faults then either became sites of post-basin-range deposition, or else they were crosscut by the bounding faults of superimposed Furnace Creek-stage basins and ranges.

Detachment faulting did not, however, end in the $\approx 6.5 \mathrm{Ma}$ tectonic reorganization because two new detachment faults formed at the beginning of the Furnace Creek stage. These are the Scotty's Castle fault (SCD, fig. 9; Oakes, 1977), located immediately northeast of the northern Death Valley fault in the area of Scotty's Castle, and the Emigrant fault of the Panamint Mountains (ED; fig. 9), which crosscut the abandoned Harrisburg detachment fault (HD; fig. 8).

In the central Death Valley rhombochasm, the timing of the tectonic reorganization between the Navadu and Furnace Creek stages is bracketed between the last-erupted, $\approx 7.5 \mathrm{Ma}$ basalt flows that form the top of the Shoshone volcanics and the first erupted units of the Greenwater volcanics - dacite flows, which have yielded dates ranging from 6.2 to $5.9 \mathrm{Ma}$ (Fleck, 1970; unpub. data, this study). Other constraints around the region are consistent with this. Whereas in this study it is assumed that the unconformity formed in this reorganization is diachronous like the others, existing data provide only this bracketing.

\section{Furnace Creek Assemblage and Tectonic Stage}

In the central Death Valley rhombochasm, the Furnace Creek assemblage includes the Furnace Creek Formation (Wright and others, 1999) - the fill of the Furnace Creek Basin (FCB, fig. 9). This formation interfingers to the southeast with the Greenwater Volcanics, the collective term for Furnace Creek-stage eruptive units of the central Death Valley volcanic field. To the west and southwest in the rhombochasm, in 
the Badwater Basin (BB; fig. 9), the equivalent section has been named the Copper Canyon Formation (Holm and others, 1994). And in the southern part of the rhombochasm, in an array of parallel north-trending half-grabens, the Furnace Creek assemblage has been mapped as the Funeral Formation (fig. 9; Wright and Troxel, 1984). This is a miscorrelation because the Funeral Formation is part of the Badwater assemblage in its type locality (the Furnace Creek Basin; McAllister, 1970).

Furnace Creek strata are found in numerous other areas to the west and northwest of the central Death Valley rhombochasm, including the Nova Basin (NB; fig. 9), where they constitute all but a relatively thin basal part of the Nova Formation, and in the Saline Range (SR; fig. 9), where all of the mafic lavas capping this range are part of this assemblage. The Furnace Creek assemblage also includes the stranded lavas and lesser interbedded deposits that cap the Last Chance Range (LCR; fig. 9), and most of the current mountain ranges that intervene between the Emigrant detachment fault (ED) of the Panamint Range and the Sierra Nevada (fig. 9).

In the southern part of Owens Valley, the oldest known basin-fill deposits consist of lacustrine strata that directly underlie bimodal volcanic rocks dated at 5.3 to $6.0 \mathrm{Ma}$ (Duffield and others, 1980). These deposits are the lower (pre- $\approx 3 \mathrm{Ma}$ ) part of the Coso Formation and are part of the Furnace Creek assemblage. Owens Valley evidently formed in the late Pliocene (at the beginning of the Badwater tectonic stage; St. Amand and Roquemore, 1979), and the lower, Furnace Creek part of the Coso Formation was probably deposited in a broad shallow basin that extended between the Panamint Range and the Sierra Nevada range front (fig. 9).

The structural framework in the Furnace Creek stage was complex within the central Death Valley rhombochasm, but relatively simple elsewhere in the region (fig. 9). Throughout the Navadu tectonic stage, the whole of the central Death Valley rhombochasm had been a single supradetachment basin, with only one major internal structure - the Sheephead fault (fig. 8). At the start of the Furnace Creek stage, numerous small nested basins formed within the rhombochasm (fig. 9), many of which were bounded by moderate-angle, strongly listric faults that cut across the freshly abandoned Amargosa detachment fault and, locally, the Sheephead fault (see Wright and Troxel, 1984). The largest of these nested basins was the Badwater Basin (BB), a half-graben bounded by the central Death Valley fault (CDVF; fig. 9), which formed at $\approx 7 \mathrm{Ma}$. The Badwater Basin formed near the western margin of the rhombochasm, such that only a small part of the Artist Drive Basin-fill lies to the west of it, on the eastern flank of the Panamint Range (compare figs. 8 and 9). The Furnace Creek half-graben (FCB) and the southern Death Valley graben formed along the bounding strike-slip faults of the same names, at the northeast and southwest margins of the rhombochasm. The Grand View strike-slip fault (GVF) formed in the central part of the rhombochasm at $\approx 7 \mathrm{Ma}$, and a narrow, shallow half-graben developed on the southwest side of this structure. Further, an array of small parallel half-grabens formed that projected northward from the southern Death Valley Basin into the center of the rhombochasm. Similar structures are present within the eastern part of the Furnace Creek Basin (FCB). Within the central Death Valley rhombochasm, the locus of tectonic activity migrated progressively westward during the Furnace Creek tectonic stage.

To the south of the rhombochasm, subsidence continued in the Military Canyon Basin through the Furnace Creek stage (MCB; figs. 8 and 9); but at a lower rate and over a smaller area than in the Navadu stage. Immediately to the northwest of the rhombochasm, along the northern Death Valley fault (NDVF), a strike-slip basin of the same name developed during the Furnace Creek stage. In the preceding Navadu stage, the area of this basin had been part of the Navadu Basin (NVB; fig. 8). Further north, across the northern Death Valley fault, a supradetachment basin formed over the Scotty's Castle detachment fault (SCD; fig. 9) at the north end of the Grapevine Mountains (GM).

To the west, the areas that are now the Eureka Valley Basin, the Saline Range, and the Saline Valley Basin (EB, SR, and SB) were evidently occupied by a single basin between $\approx 6$ and $\approx 3 \mathrm{Ma}$ (compare figs. 9 and 10; Burchfiel and others, 1987). The Saline Range uplift, which formed at $\approx 3 \mathrm{Ma}$, is capped by the same thick Furnace Creek-age and mainly volcanic basin-fill that underlies the younger Badwater strata in the two basins on either side of it (compare figs. 9 and 10; Blakely and McKee, 1985). Thus, the western part of the region shows the same pattern of progressive fragmentation of the landscape, during basin-range tectonism, as is found in the eastern and central parts of the region. Only the timing is different, reflecting the progressive westward migration of basin-range tectonism.

Finally, the area extending from the Garlock fault northward to the south end of Saline Valley Basin (SVB), and from the Emigrant detachment fault (ED) to the Sierra Nevada may all have been one vast shallow basin in the Furnace Creek stage (fig. 9), as discussed above. Syntectonic deposits of this stage are thickest in the northeastern part of this area, which has been called the Nova Basin (NB; fig. 9); however, there are no known basin boundaries that predate $\approx 3 \mathrm{Ma}$ within this whole area.

Volcanic rocks of the Furnace Creek stage are mainly basalts, with lesser but conspicuous associated felsic tuffs and lavas. In the central Death Valley volcanic field, the associated felsic rocks are biotite-rich dacites. This is the only discrete volcanic field of this tectonic stage. Throughout the major part of the region, from the Grapevine Mountains (GM) and Panamint Range westward, strongly basalt-dominated bimodal volcanic rocks are widely present, and gaps in continuity may largely be a function of younger cover or of erosion. In all of this area, the associated felsic rocks are mainly phenocryst-poor rhyolites. The major felsic eruptive unit of this broad area is a group of $\geq 6$ closely related tuffs known collectively as the $\approx 3.2$ Ma tuff of Mesquite Spring, which is found as an ash-fall tuff throughout much of the Death 


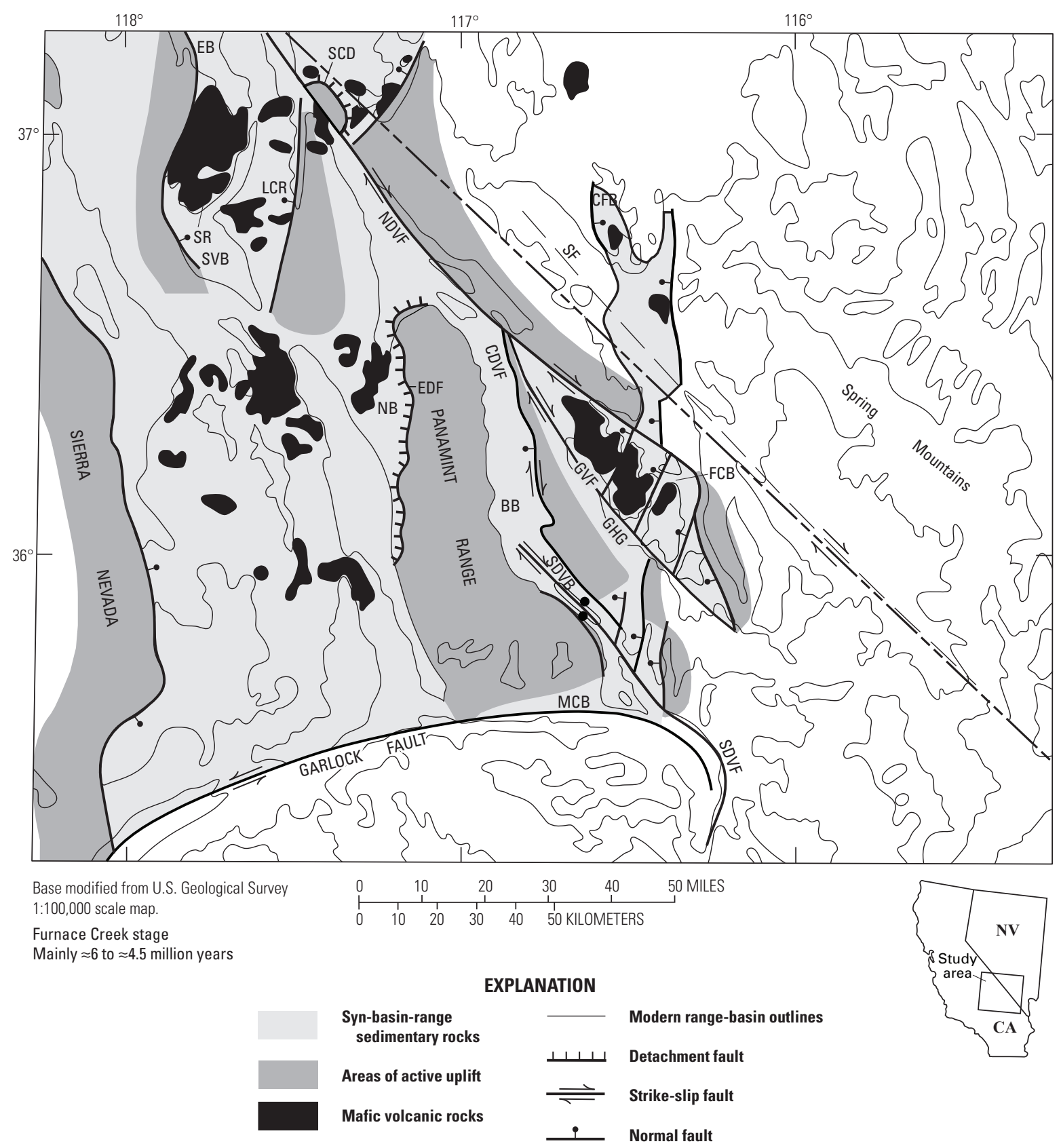

Figure 9. Present-day distribution of the $\approx 7$-to- $\approx 3.5$-Ma syn-basin-range Furnace Creek assemblage, the major faults known to be active, and the distribution and compositions of volcanic rocks erupted in the Furnace Creek stage. Major active faults include northern Death Valley-Furnace Creek fault (NDVF), central Death Valley fault (CDVF), southern Death Valley fault (SDVF), Scotty's castle detachment fault (SCD), and Emigrant detachment fault (EDF). Labeled basins include Furnace Creek Basin (FCB), Badwater Basin (BB); and Greenwater half-graben (GHG), a narrow shallow basin downthrown on the mainly strike-slip, down-to-the-southwest, and small-offset Grand View fault (GVF). LCR is the current area of the Last Chance Range. 
Valley region, and probably was sourced in the vicinity of Scotty's Castle because it is most proximal in character there.

Small outliers of Furnace Creek-stage basalts are found in the northeasternmost part of the region, in and near the Crater Flat Basin (CFB; fig. 9). These rocks are part of a progressively waning stage of activity in the southwest Nevada volcanic field (Fridrich and others, 1999), which has continued even into the latter part of the Badwater tectonic stage. Strictly speaking, these last-mentioned basalts are post-basin-range.

Sedimentary rocks of the Furnace Creek assemblage include abundant alluvium, playa siltstones, and lesser rockavalanche breccias. Other rock types, such as fluvial conglomerates and ground-water discharge deposits, are present but are relatively rare. The alluvial deposits of the Furnace Creek assemblage are markedly less tuffaceous on average than those of the Navadu assemblage, evidently because the last voluminous eruptions of felsic ash in the region occurred at $\approx 7.5 \mathrm{Ma}$, near the end of the Navadu tectonic stage. Whereas alluvial conglomerates constitute $\approx 20$ percent of the sedimentary budget in the Navadu assemblage, they constitute nearly 50 percent of the exposed Furnace Creek sedimentary strata. Moreover, gypsum became even more abundant in lacustrine deposits after $\approx 7 \mathrm{Ma}$, and freshwater limestone became less abundant.

\section{The $\approx 4.5$ to $\approx 3$ Ma Tectonic Reorganization}

The third and final tectonic reorganization in the Death Valley region occurred between $\approx 4.5$ and $\approx 3 \mathrm{Ma}$ (fig. 4 ). The belt of basin-range tectonism changed little in this reorganization (compare figs. 9 and 10). Specifically, that part of the central Death Valley rhombochasm that lies east of the Badwater Basin was abandoned; otherwise, there was little change in the boundaries of the belt. However, activity was strongly concentrated in the eastern part of this belt before this reorganization, in the Furnace Creek tectonic stage, and has been more evenly distributed across this belt since $\approx 3 \mathrm{Ma}$, with the greatest focus of tectonism at the western margin.

The timing of this most recent tectonic reorganization is best constrained in the Furnace Creek Basin, where the resultant unconformity closely underlies a $4.5 \mathrm{Ma}$ flow of the Funeral Basalt in the eastern part of the basin, and closely overlies the $\approx 3.2$ Ma tuff of Mesquite Springs in the western part (Knott and others, 2008; Fridrich and others, in press). Other constraints in the region all fall within this range, with the majority near the younger end.

The major change during the $\approx 4.5$-to- $\approx 3$-Ma tectonic reorganization was in tectonic style. Whereas the Furnace Creek (FCB) and southern Death Valley Basins SDVB; figs. 9 and 10) both opened up via north-northeast - south-southwest extension during the Furnace Creek stage, these basins have undergone contraction in the same direction since $\approx 4 \mathrm{Ma}$. Several other areas in the region show a similar abrupt onset of contraction in this direction at $\approx 3 \mathrm{Ma}$, as discussed below.
The most striking thing about the $\approx 4.5$-to- $\approx 3$-Ma tectonic reorganization is that it ushered in the strain pattern of the ongoing Badwater tectonic stage - the pattern that exists today. If we could reverse the clock, it would be difficult to recognize the Death Valley region at $5 \mathrm{Ma}$; but by shortly after $3 \mathrm{Ma}$, the present-day pattern of active faults, and the resultant pattern of rising ranges and subsiding basins had formed (compare figs. 9 and 10).

In the ongoing Badwater stage, contraction in the NNESSW direction partly balances extension in the WNW-ESE direction, such that the magnitude of strike-slip strain may exceed that of extension for the first time since basin-range extension began in the region at $\approx 16 \mathrm{Ma}$.

\section{Badwater Assemblage and Tectonic Stage}

In the area of the Furnace Creek paleobasin (FCB), the Badwater assemblage is named the Funeral Formation, which consists mainly of alluvium derived from the Paleozoic and Neoproterozoic sedimentary rocks of the adjacent Funeral Mountains (FM; fig. 10). Additionally, it includes the $\approx 4.5 \mathrm{Ma}$ Funeral basalts, which locally interfinger with the basal part of the Funeral Formation and extend to the southeast. In the area of Copper Canyon (CC), on the east flank of the Badwater Basin (BB; fig. 10), the Funeral Formation consists dominantly of alluvium and landslide megabreccias derived from the $1.7 \mathrm{Ga}$ basement rocks exposed in the adjacent Copper Canyon Turtleback (Drewes, 1963; Holm and others, 1994; Knott and others, 1999), the basin floor of the central Death Valley rhombochasm.

Badwater strata have been described at two other sites in the Badwater Basin, one called Mushroom Rock (MR) and another adjacent to the Mormon Point turtleback (MP; fig. 10; Knott and others, 1999). Both are dominated by alluvial conglomerates. In the southern Death Valley Basin (SDVB; fig. 10), Badwater assemblage strata have been documented in two large pressure ridges: the Confidence Hills, where it has been called the Confidence Hills Formation (fig. 10; Beratan and others, 1999), and the Noble Hills to the south, in which Brady (1986) mapped the Bad-water strata as "older Quaternary fan deposits."

In the Cottonwood Mountains (CM; fig. 10), the Badwater assemblage consists of two stacked lithologic units, named by Snow and White (1990) the "volcanics/marl" and "upper conglomerate," in which the basal "marl" is a lacustrine calcareous tuffaceous deposit composed mainly of waterlaid tuff derived from the $\approx 3.2$ Ma tuff of Mesquite Springs. Throughout most of the area of distribution of the Badwater assemblage (fig. 10), strata that are mapped as surficial deposits lie within the area of active tectonism; thus, they are technically part of this assemblage even though most are too young to yet record much tectonic information. The one exception to this is the Furnace Creek Basin, which became part of the post-basinrange domain at $\approx 2 \mathrm{Ma}$ (Fridrich and others, in press). 


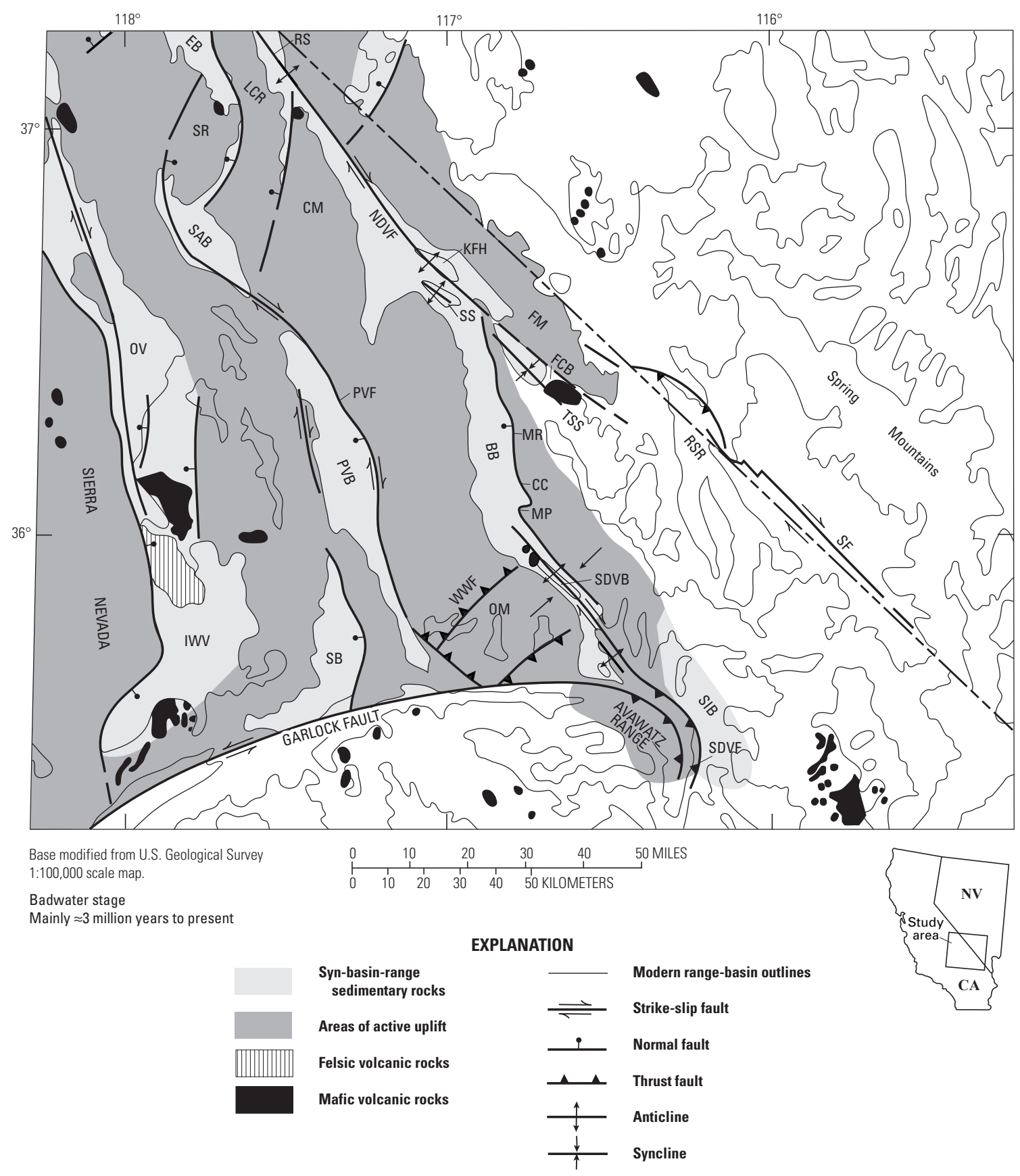

Figure 10. Present-day distribution of the $\approx 3.5 \mathrm{Ma}$-to-present syn-basin-range Badwater assemblage, the major faults known to be active, and the distribution and compositions of volcanic rocks erupted in the Badwater stage. Actively subsiding basins of this stage include Owens Valley (OV), Indian Wells Valley (IWV), Panamint Valley Basin (PVB), and the Badwater Basin (BB). The Saline Valley and Eureka Valley Basins (SB and EB) are separated by the Saline Range (SR), which is largely composed of basin-fill deposits of the Furnace Creek and Navadu Assemblages. The shallow Silurian Basin (SIB) is probably a foreland basin of sorts forming in front of the Avawatz Range thrust uplift. Other transpressional features of this ongoing stage include Texas Spring syncline (TSS) in the Furnace Creek Basin and pressure ridges at several locations: at the north end of the Resting Spring Range (RSR), at Rodger's Spring (RS), and at Kit Fox Hills and Salt Springs (KFH and SS). Large pressure ridges in the northern and southern parts of the southern Death Valley Basin (SDVB) are called the Confidence Hills and the Noble Hills. Additionally, the Wingate Wash fault has been reactivated as a thrust fault in the Badwater stage and other major faults of the Owlshead Mountains (OM) all show evidence of recent oblique-thrust offset. Other labeled features include the Last Chance Range (LCR), Cottonwood Mountains (CM), Panamint Valley-Hunter Mountain fault (PVF), and Funeral Mountains (FM). Badwater Assemblage strata are exposed in the central Death Valley Basin at Mushroom Rock (MR), Copper Canyon (CC), and at Mormon Point (MP). Also shown is the Resting Spring Range (RSR). 
The major basins of the ongoing Badwater tectonic stage are Death Valley (consisting of the southern Death Valley, Badwater, and northern Death Valley Basins), and the basins of Eureka (EB), Saline Valley (SVB), Panamint Valley (PVB), Searles (SB), and Owens/Indian Wells Valleys (OV/IWV; fig. 10). The bounding faults of these basins are mainly strike-slip or oblique-slip faults, rather than simple normal faults. One aspect of this modern framework that is underappreciated is the abundance of features that indicate recent northeast-southwest contraction.

In the Furnace Creek Basin (FCB; fig. 9), all pre-Badwater-stage strata have been shortened, forming a large northwest-trending fold in the center of the basin named the Texas Spring syncline (TSS; fig. 10; McAllister, 1970). This fold was progressively buried upsection from $\approx 4.5$ to $\approx 2$-Ma by the Funeral Formation, which thickens from as little as $\approx 70 \mathrm{~m}$ on the flanks of this fold, to $\geq 300 \mathrm{~m}$ in the center (McAllister, 1970; C. Fridrich, unpub. data, about 2005).

The southern Death Valley Basin (SDVB; fig. 10), another Furnace Creek-stage graben, has also been downwarped into a syncline since $\approx 4 \mathrm{Ma}$, resulting in inward tilting of basin-fill (mainly alluvial) deposits on either side of this basin at dips that exceed depositional angles. The degree of tilting is greatest in pre- $\approx 4$ Ma strata, and decreases upsection through exposed Badwater-stage strata. In this basin, the rate and extent of downwarping have kept pace with the ongoing extensional subsidence of the adjacent Badwater Basin. Hence, southern Death Valley is still a depositional basin, despite the current contractional regime. The large anticlinal pressure ridges that extend down the axis of the southern Death Valley Basin (SDVB) are separated, in the middle of the basin, by a large releasing step-over in the southern Death Valley fault. Because of the contractional regime, this releasing step-over is a site of neither active contraction nor extension.

The southern Death Valley (SDVF) and Garlock faults (fig. 10) wrap around the northeastern and eastern front of the Avawatz Range and have acted as oblique thrust faults during the Badwater stage. This thrusting has uplifted the Avawatz Range (fig. 10), which is capped by a perched, but, as yet, little eroded syntectonic basin fill of pre-Owlshead age ( $\approx 19 \mathrm{Ma}$ ? at the top; Spencer, 1993). Thermochronometric uplift data for the Avawatz Range show that uplift began at $\approx 7 \mathrm{Ma}$, at the start of the Furnace Creek tectonic stage and has occurred primarily since $\approx 4 \mathrm{Ma}$ (Reinert and others, 2003). These data are consistent with the stratigraphic evidence in the southern Death Valley Basin, where clasts of the pre-Tertiary rocks of the Avawatz Range abruptly appear in the stratigraphic record for the first time near the base of local Badwater strata.

Also during the Badwater stage, a large concentric downwarp, a foreland basin of sorts, has developed in front (eastward and northeastward) of the Avawatz uplift, in the area of the Silurian Basin (SIB) and the southern part of the south Death Valley Basin (SDVB; fig. 10; Menges and others, 2005, 2006; Miller and others, 2007). Contractional structures that are no older than Badwater age also have formed along the Stateline fault (SF) at the north end of the Resting Spring Range (RSR; Menges and others, 2003), and along the northern Death Valley fault (NDVF) at the Kit Fix Hills (KFH), at Salt Spring (SS), and at Rodger's Spring (RS; fig. 10). Further, much of the active faulting within the Owlshead Mountains (OM) is transpressional (Menges and others, 2005, 2006; Miller and others, 2007; fig. 10). Little contraction occurred in any of these areas before $\approx 4 \mathrm{Ma}$; the rare examples known are localized at strongly constraining bends of major strike-slip faults.

The known contractional structures of the Badwater stage are all concentrated along the eastern margin of the belt of Badwater-stage tectonism in the region (fig. 10). If similar structures are present in the less-studied part of the region that lies to the west, they have not been identified. Thus, it is unclear from existing data if these structures reflect region-wide contraction in the north-northeast - south-southwest direction, or simply a boundary effect along the eastern margin of the current syn-basin-range domain. However, no features like these are known from any of the three preceding stages of basin-range tectonism.

As with the Navadu and Furnace Creek assemblages, the Badwater assemblage records evidence of within-stage structural evolution. For example, in the Badwater Basin, the basinbounding faulting has locally re-broken basinward (westward) with time, resulting in abandonment of some minor low-angle segments of the central Death Valley fault, specifically, those exhumed, strongly anti-listic fault surfaces known as the Death Valley "turtlebacks." This has resulted in the stranding and relative uplift of early Badwater assemblage basin-fill that was deposited on these low-angle segments, such as in Copper Canyon (Knott and others, 1999).

Volcanism during the Badwater tectonic stage has been almost purely basaltic, except in Owens Valley, where it has been bimodal (Pakiser and others, 1964). Owens Valley also is the only locale where a sizeable volcanic field has formed in this ongoing stage. In the remainder of the region, volcanic fields of this stage are small and are limited to the earliest part of the Badwater stage, such as in the Furnace Creek Basin where the Funeral basalts were emplaced at $\approx 4.5 \mathrm{Ma}$ (Wright and others, 1999). East of Owens Valley and since $\approx 3 \mathrm{Ma}$, Badwater-stage basalts have erupted mainly at small centers and clusters of centers producing cinder cones, maars, and tiny shield volcanoes. The rate of volcanism in the Badwater stage has been small relative to that of the previous stages of basinrange tectonism, except in Owens Valley (Pakiser and others, 1964).

Badwater assemblage strata extend the trends established by the preceding basin-range assemblages, with greater abundances of alluvium and of gypsum, and lesser abundances of fluvial deposits and freshwater limestone than in the Furnace Creek assemblage. 
Provenance is the feature that most clearly distinguishes Badwater strata from all older syntectonic Cenozoic deposits of the Death Valley region. The provenance of even the oldest Badwater deposits is similar to late Holocene deposits of the same depositional environment, found in the same locality. In those cases where the provenance differs, it does so in a manner that is explicable in terms of predictable evolutionary processes within the modern tectonic, and resulting topographic regime. For example, most upsection changes in provenance observed can be explained as a consequence of ongoing erosional unroofing in the existing source area, stream capture, and similar ongoing processes.

\section{Post-Basin-Range Sequence}

In the wake of the migrating wave of basin-range tectonism, that part of the Death Valley region that lies east and northeast of Death Valley physiographic feature has become the site of deposition of the last sequence of Cenozoic sediments (fig. 11), which is termed "post-basin-range." Other than in the Owlshead Mountains (OM; fig. 11), no post-basin-range sediments are present from Death Valley to the Sierra Nevada range-front, by definition, because this region is one of ongoing tectonism of the Badwater stage.

The post-basin-range deposits of the Death Valley region rarely have any formation names assigned to them. The major exception is the Tecopa "lake-beds" (TLB; fig. 11) near the east-central margin of the central Death Valley rhombochasm (Morrison, 1999), discussed above. These "lake beds" actually are mainly paludal deposits (R. Forester and M. Reheis, USGS, oral commun., 2003), from which a date of $5.1 \mathrm{Ma}$ has been obtained from a tuff near the base (Morrison, 1999). Because they are predominantly untilted and poorly consolidated, many post-basin-range strata have been mapped as "old Quaternary alluvium" (for example, Burchfiel and others, 1983), even where they are as old as middle Miocene at the base, on the basis of interbedded tephras.

Post-basin-range strata are characteristically untilted and unfaulted; however, there are local exceptions adjacent to faults that have remained active at low rates within basins that have otherwise been abandoned tectonically. The basal contact of this sequence is, in some cases, an angular unconformity, and in others the top of a section of fanning dips. The base is that horizon at which significant tectonic tilting and faulting of the beds is buried upsection within the vast majority of a basin. The base of the post-basin-range sequence ranges from a maximum age of $\approx 12 \mathrm{Ma}$, in the Owlshead Mountains (OM) and all but the westernmost part of the Pahrump Basin (PB), to as young as $\approx 2 \mathrm{Ma}$ areas immediately east of Death Valley (fig. 11).

Post-basin-range volcanism is minor. The few volcanic units that have erupted within the post-basin-range domain are small basaltic centers in the area of the southwest Nevada volcanic field. They evidently are the final declining phase of activity of this large and long-lived magmatic system.
The post-basin-range strata generally consist of only a thin ( $\leq 100$ s of meters) capping layer above syn-basin-range basin fill, even where the base of this sequence is middle Miocene. This reflects a slow deposition rate. The high deposition rates of the syn-basin-range sequence must, therefore, be tectonically driven; for example, by formation and maintenance of steep scarps between actively subsiding basins and adjacent actively uplifting ranges.

The vast majority of post-basin-range deposits consist of alluvial and playa deposits; however, fluvial, eolian, groundwater discharge, and other deposits are part of the sequence. As is true for the strata of the Badwater assemblage, the provenance of the post-basin-range deposits is generally similar to that of the late Holocene deposits of the same depositional environment, found in the same locality. A major exception to that relation is seen in some of the basins in which basin-range tectonism ended in the Miocene. In many of these basins, fluvial deposits and even some of the more far-traveled alluvial sediments within the post-basin-range sequence record a trend toward more distal derivation of clasts with time. In most cases, this trend is indicated by abrupt upsection provenance changes, which record the reintegration of drainage between previously closed basins, because of erosional removal or depositional overtopping of the topographic barriers that once divided these basins, after strong local tectonism ceased (Lundstrom and Warren, 1994; Menges and others, 2008). The fragmentation of the landscape that results from basinrange tectonism is, thus, impermanent, and the trend toward drainage reintegration probably begins as soon as significant tectonism ceases.

\section{Discussions}

1. What caused the tectonic reorganizations of the Death Valley region?

It has long been known that the loci of basin-range tectonism and of related volcanism have migrated in a regular manner across the Death Valley region, specifically, and across the basin-range province, in general, during the late Cenozoic (for example, see Armstrong and others, 1969; and McKee, 1971; Axen and others, 1993). The current study departs from most previous ones in the recognition that this has been a strongly episodic process, not a continuous one. In the Death Valley region, at least, westward migration of the tectonic locus and coeval reorganizations of strain patterns have occurred primarily in step-wise fashion - in a series of discrete short-lived tectonic reorganizations. The fact that these reorganizations were roughly synchronous over an entire region indicates that they are caused by processes that operate on a similarly large, if not even a larger scale.

The most notable of the tectonic reorganizations that occurred during basin-range extension in the Death Valley 


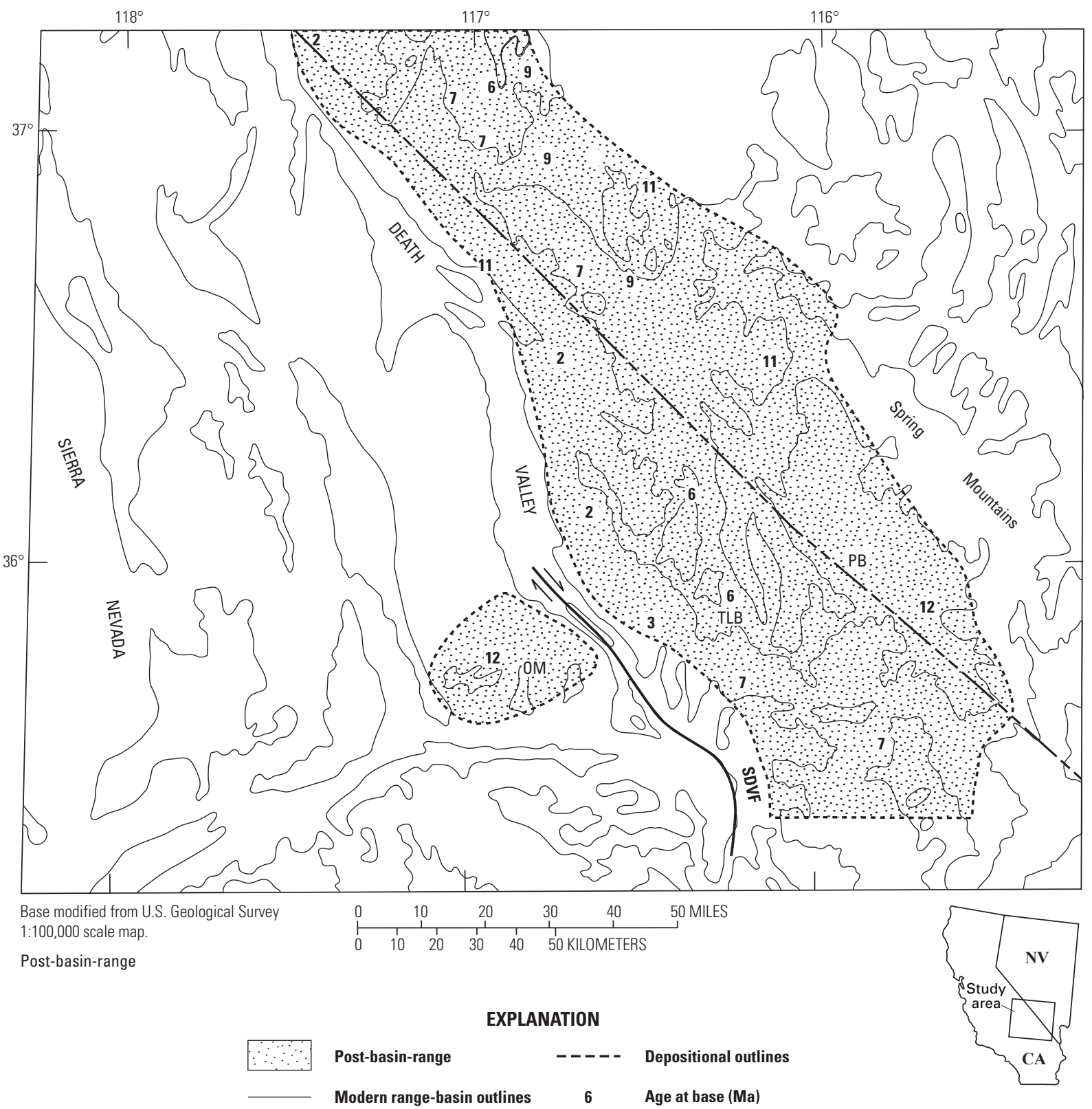

Figure 11. Distribution of the post-basin-range sequence of the Death Valley region, and the estimated ages (Ma) of the strata at the base of this sequence, showing the westward younging of the base-age. 
region is the one that occurred from $\approx 12.5$ to $\approx 11.5 \mathrm{Ma}$. Whereas some of the major strike-slip faults of the region were clearly present before $\approx 12.5 \mathrm{Ma}$, rapid slip and large offsets on most of these faults evidently began at this time. Moreover, an abrupt climate change occurred at $\approx 12.5$, possibly caused by initial uplift of an ancestral Sierra Nevada, resulting in a rain shadow over the region. The latter circumstance suggests that this reorganization involved changes that extended beyond the Death Valley region, and in fact beyond the Basin-Range province.

Geodetic studies show that the northern Walker Lane belt, the Death Valley region, and the associated part of the eastern California shear zone that lies to the south currently accommodate $\approx 25$ percent of the total right-lateral slip between the Pacific and North American plates (Hammond and Thatcher, 2004; and references therein). Moreover, the San Andreas fault, which accommodates about 50 percent of the strike-slip plate motion, shows a long-term correlation in its tectonic evolution to reorganizations of the boundary between these two plates (Atwater and Molnar, 1973). Therefore, an obvious hypothesis to test is that the timing of tectonic evolution in the Death Valley region also may be related to tectonic reorganizations of this nearby plate boundary.

The timing of the major observed events in the tectonic evolution of the Death Valley region, summarized from above, are as follows: (1) $\geq 40 \mathrm{Ma}$ - onset of extension-related but pre-basin-range basinal sedimentation, (2) $\approx 19 \mathrm{Ma}$ - cessation of deposition at onset of $\approx 3$ m.y. lacuna, (3) $\approx 16 \mathrm{Ma}$ - end of lacuna and onset of basin-range tectonism in the eastern half of the region, (3) $\approx 12.5$ to $11.5 \mathrm{Ma}$ - first reorganization of basin-range extension, (4) bracketed between $\approx 7.5$ and $\approx 6.2 \mathrm{Ma}-$ second reorganization, and (5) $\approx 4.5$ to $\approx 3 \mathrm{Ma}$ - third reorganization. Additionally, there is the unconformity at roughly $28 \mathrm{Ma}$, which Snow and Lux (1999) considered an important stratigraphic boundary, but was not used in the stratigraphic model of the current study because it is not a regionally traceable stratigraphic boundary.

For comparison, the major events in the evolution of the Pacific-North American plate boundary to the west and southwest of the Death Valley region are: (1) between $\approx 45$ and $\approx 40 \mathrm{Ma}$ - worldwide plate motions changed, and the Pacific plate began moving away from the North American plate, (2) between $\approx 25$ and $29 \mathrm{Ma}$ - a major plate reorganization resulted from intersection of the Pacific - Farallon spreading center with the subduction zone bordering the North American plate just south of the Mendicino fracture zone, (3) at $\approx 19 \mathrm{Ma}$, spreading perpendicular to the trench ceased between the Monterey and Pacific plates, (4) from $\approx 12.5$ to $\approx 11 \mathrm{Ma}$-- the eastern boundary of the Pacific plate jumped eastward from a large segment of the East Pacific Rise into the vicinity that is now Baja California and major slip began on strike-slip faults along the west coast of the North American plate from the Mendicino Fracture Zone to the southern tip of Baja California, (5) in a series of steps beginning at $\approx 6.5 \mathrm{Ma}$ and ending at $\approx 3.5$ Ma with the major changes at the beginning and end, the
Mathematician spreading ridge was abandoned in favor of the East Pacific Rise, and seafloor spreading began in the Gulf of California (Atwater, 1970; Mammerickx and Klitgord, 1982; Ward, 1991; Bohannon and Parsons, 1995). All of the above reorganizations of this plate boundary were short-lived events that separated longer periods in which the loci, directions, and rates of seafloor spreading were relatively uniform (Mammerickx and Klitgord, 1982).

The correlation between the timing of the tectonic reorganizations of the Death Valley region and those of the PacificNorth American plate boundary is too close to be coincidental. Moreover, the punctuation of the tectonic evolution by shortlived episodes of radical change, separating long stages characterized by slow monotonic change, is essentially the same in both cases. This supports models that explain the widely distributed transtensional tectonism in southwestern North America since $\approx 40 \mathrm{Ma}$ as resulting from traction imposed by the neighboring, divergent Pacific plate.

The only event in the Death Valley region that may not correlate in a straightforward way to an event at the plate boundary to the west and southwest is the onset of basin-range extension at $\approx 16 \mathrm{Ma}$. Based on essentially the same data, some workers have interpreted a plate reorganization event starting at $\approx 16 \mathrm{Ma}$ (Barrash and Venkatakrishnan, 1982), and other workers have not (Mammerickx and Klitgord, 1982). Nonetheless, $16 \mathrm{Ma}$ is a date at which basin-range extension and related volcanism began over large parts of the Northern Basin and Range province, and giant outpourings of basalt started or peaked on adjacent parts of the Columbia River Plateau (fig. 1; Barrash and Venkatakrishnan, 1982). Thus, the $\approx 16$ Ma event in the Death Valley region is not an isolated occurrence. Even if it is not related to a plate boundary reorganization event, it evidently is part of a pulse of tectonic and related volcanic activity that affected a large part of the western United States.

If the tectonic reorganizations of the Death Valley region were driven by those along the Pacific-North American plate boundary, then a correlative pattern should be found at least in the northern part of the Walker Lane belt, and possibly in other parts of western North America. In fact, Henry and others (2007) have documented that significant changes in strain patterns occurred in the northern part of the Walker Lane belt at $\approx 12 \mathrm{Ma}$ and at $\approx 3 \mathrm{Ma}$. Moreover, a significant unconformity dating from $\approx 6$ to $\approx 7 \mathrm{Ma}$ also has been found in part of this region in an unpublished study (C.D. Henry, Nevada Bureau of Mines and Geology/University of Nevada-Reno, oral commun., 2010).

It may be significant that the onset of major slip along the large strike-slip faults internal to the Death Valley region began at the same time that it began along the west margin of the North American plate - at $\approx 12.5 \mathrm{Ma}$. This suggests that the current relation, in which a major fraction of the PacificNorth American plate strike-slip offset is accommodated in the Eastern California shear zone-including the Death Valley region-began at this time. 
2. What processes underlie the nature of the changes that occur during tectonic reorganizations?

\section{A. Structural Changes}

Strain patterns are a result of a complex interplay between the regional stress regime and the strength of the lithosphere in three dimensions, including previously formed weaknesses. Some features of the strain regime probably are driven largely, if not entirely, by the regional stress regime, such as the relative proportion of extension to strike-slip strain.

Another feature that is probably controlled by the regional stress regime is the direction of upper-plate transport during extension. Based on existing mapping, the estimated azimuth of extensional transport in the Death Valley region has changed progressively from roughly $270^{\circ}$ in the Owlshead tectonic stage to roughly $300^{\circ}$ in the ongoing Badwater stage (see figs. 6, 7, 8, 9, and 10). Thus, it has been slowly rotating clockwise throughout the time of basin-range extension. The same change has been documented in many other parts of southwestern North America, and it can be related to the evolution of the boundary between the Pacific and North American plates since the beginning of the middle Miocene (Bohannon and Parsons, 1995). In contrast, the style of faulting and of other deformational processes most likely reflects the state of strength in the crust, which has undoubtedly changed in a progressive manner during basin-range extension.

The observed progressive changes in the style of faulting in the Death Valley region are summarized as follows. (1) In the Hells Gate-Owlshead tectonic stage, most if not all of the major basin-bounding faults were detachment faults (fig. 6) that formed at low angles (Holm and Dokka, 1993; Fowler and Calzia, 1999). None of these early detachment faults have the classic turtleback form. Turtleback-like mullions are locally present on them, but the overall forms are mainly subhorizontal and subplanar. (2) The major basin-bounding faults of the Navadu stage are about equally divided between detachment faults and moderate- to high-angle range-front faults (fig. 8). Some of the detachment faults of this stage have classic turtleback forms, but those that formed in the Owlshead stage and remained active into the Navadu stage retained their subplanar forms. (3) The major basin-bounding faults of the Furnace Creek stage are dominantly moderate- to high-angle range-front faults. Two new detachment faults formed and were active through this stage (fig. 9), and both have strongly developed turtleback forms. (4) And in the Badwater tectonic stage, there are no provable active detachment faults. The major basin-bounding faults are largely moderate- to high-angle faults, and are higher in angle and evidently more planar (less listric), on average, than in the three preceding stages of basinrange extension (fig. 10).

Some workers have suggested that low-angle normal faulting (detachment faulting?) is still ongoing in the Death Valley region (Cichanski, 2000; Diderickson, 2005; Numelin and others, 2007). All three of the well-documented examples are in areas in the far southern part of the region, adjacent to the Garlock fault. Thus, if there has been detachment faulting in the Badwater stage, it evidently has been confined to a narrow perimeter immediately adjacent to a very active strike-slip fault. In any case, the faulting of the Badwater stage is unquestionably the highest-angle faulting, on average, of the four stages of basin-range extension.

This trend toward ever-higher-angle faulting is probably a consequence of progressive thinning of the crust during basinrange extension. The crust of the Death Valley region was strongly overthickened when basin-range extension began, because of the preceding late Paleozoic through Mesozoic contraction. This belt of overthickened crust was continental in scale, and the detachment faults of western North America (fig. 1) are found only within this belt (Wust, 1986).

The strong contraction in this belt resulted in a crust in which sialic material extended much deeper than in normalthickness crust, and thus to depths in which this material was hotter. The resultant high mid-crustal ductility, at the onset of basin-range extension, may have favored the formation of low-angle normal faults (Yin, 1989). Crustal thinning reversed that pattern, and progressive loss of mid-crustal ductility thus favored increasing steep faulting with time. Why the dominant exposed forms of the detachment fault surfaces changed during the interval of basin-range extension is unknown, but we would speculate that it is related to progressive crustal thinning, and resultant changes in large-scale ductility or other crustal properties.

\section{B. Changes in Volcanism}

The rate of volcanism during basin-range extension in the Death Valley region generally has risen and fallen through time with the rise and fall in the extension rate. The one exception is the volcanic hiatus at the beginning of the Navadu stage, which evidently coincided with the interval of maximum extension rate, as discussed above. A general correlation between the rates of extension and magmatism supports the concept that extension-related magmatism results from decompression melting in the upper mantle.

The overall trend from: (1) andesite-rhyolite, to (2) quasibimodal, to (3) basalt-dominated true bimodal, to (3) almost strictly basaltic compositions (fig. 4) throughout the last 15 m.y. in the Death Valley region is similar to magma compositional trends observed in other parts of the Basin and Range Province (Christiansen and Lipman, 1972). At least two major factors may contribute to this pattern. First, nearly all volcanism on earth is fundamentally basaltic, and magma compositions other than basalt probably form only in crustal magma chambers. Thus, volcanism that is too feeble to form crustal chambers can be nothing but basaltic. Moreover, complex associations of different compositions require a high magmageneration rate. Additionally, crustal thickness may play an important role. It may be difficult for basaltic magma to pass 
through a strongly overthickened crust without undergoing extensive fractionation and assimilation. This may explain the scarcity of erupted basalts at the inception of extension, when the crust was still thick.

Another factor that may be involved is subduction, which was occurring along the west coast of southern California at the inception of basin-range extension in the Death Valley region. By $\approx 10 \mathrm{Ma}$, subduction had ceased along the plate boundary immediately to the west of the Death Valley region (Atwater, 1970). Thus, the early volcanism of the region may have been related to both subduction and extension; whereas the post $\approx 10$ Ma volcanism was related to extension alone (Christiansen and Lipman, 1972). Subduction-related volcanism is characteristically andesitic, and andesitic volcanism did largely end in the Death Valley region by $\approx 10 \mathrm{Ma}$, as discussed above.

C. Step-wise migration of the locus of tectonism and volcanism

Progressive westward stepping of the belt of strong basinrange tectonism has been a key feature of the tectonic reorganizations that have occurred in the Death Valley region. The cause of this is almost certainly local, but universal to areas undergoing extension. As the crust has thinned during basinrange extension, the sialic material in the middle crust has cooled and become less ductile. Counter-intuitively, crustal thinning may thus result in progressive strengthening of the crust. Basin-range extension probably was initially localized on some of the weakest crust - the path of least resistance. As progressive extension has "used up" that weak crust, adjacent zones of still-overthickened crust have become the new path of least resistance.

Additionally, when extension is unidirectional, the separation between the upper-crustal zone of brittle strain and the middle and lower crustal root zone of ductile strain increases as extension occurs. Moreover, the dips on major structures that transfer strain between the brittle upper crust and the ductile middle and lower crust become progressively lower with time, not only because of the increasing separation, but also because the depth to the brittle-ductile transition decreases during crustal thinning. The growing separation and progressive decrease in fault dips increase friction. This is the process that drives the slow, minor within-stage migrations in the locus of strongest tectonism. When a large-scale tectonic reorganization precipitates a radical rearrangement of the strain pattern, any part of the old pattern of faults that has excess friction is abandoned, and the locus of tectonism moves into relatively virgin crust to the west because it's weaker and closer to the ductile root zone of extensional deformation.

The crust to the west of the previous tectonic locus is not truly virgin, however, because the westward rooting of the major faults causes deep-seated extension to the west of the tectonic locus in the brittle upper crust. Thus, throughout basin-range tectonism, the lower ductile part of the crust has been extending across the whole of the Death Valley region, and even to the west, under the Sierra Nevada block. And this is why the nature of volcanism and the style of faulting has evolved in a more-or-less uniform manner throughout the region during basin-range extension.

\section{Acknowledgments}

We thank M.C. Reheis, R.G. Bohannon, E. Anderson, J.C. Cole, T.W. Judkins, and M.M. Coates for thoughtful input and critiques. The understanding of the Death Valley region presented here was developed over a 20-year period of field-intensive studies that were supported through funding and other forms of support from the U.S. Geological Survey National Cooperative Geologic Mapping Program, the U.S. Department of Energy's Yucca Mountain Project and Environmental Restoration Program, the Inyo County Yucca Mountain Nuclear Waste Assessment Project, the National Park Service, and the Hydrodynamics Group. The figures and plate were drafted by M.A. Berger. 


\section{References Cited}

Andrew, J.D.R., Jr., Walker, D., Rittase, W., Monastero, F.C., and Sabin, A., 2010, Slip and Kinematic history of the Garlock fault from analysis of the Lava Mountains Miocene volcanic-sedimentary sequence, San Bernardino County, California: Geological Society of America Abstracts with Programs, v. 42, no. 5, p. 595.

Applegate, J.D.R., Jr., and Hodges, K.V., 1995, Mesozoic and Cenozoic extension recorded by metamorphic rocks in the Funeral Mountains: Geological Society of America Bulletin, v. 107, p. 1,063-1,076.

Armstrong, R.L., Ekren, E.B., McKee, E.H., and Noble, D.C., 1969, Space-time relations of Cenozoic silicic volcanism in the Great Basin of the western United States: American Journal of Science, v. 267, p. 478-490.

Atwater, Tanya, 1970, Relationship of plate tectonics to Cenozoic tectonics of North America: Geological Society of America Bulletin, v. 81, p. 3,513-3,536.

Atwater, T. and Molnar, P., 1973, Relative motion of the Pacific and North American plates deduced from sea-floor spreading in the Atlantic, Indian, and south Pacific oceans, in, Kovach, R.L., and Nur, A., eds., Proceedings of the conference on tectonic problems of San Andreas fault system: Stanford, CA, Stanford University, p. 136-148.

Axen, G.J., Taylor, W.J., Bartley, J.M., 1993, Space-time patterns and tectonic controls of Tertiary extension and magmatism in the Great Basin of western United States: Geological Society of America Bulletin, v. 105, p. 56-76.

Barrash, W., and Venkatakrishnan, R., 1982, Timing of late Cenozoic volcanic and tectonic events along the western margin of the North American plate: Geological Society of America Bulletin, v. 93, p. 977-989.

Beratan, K.K., Hsieh, J., and Murray, B., 1999, PliocenePleistocene stratigraphy and depositional environments, southern Confidence Hills, Death Valley, California, in Wright, L.A. and Troxel, B.W., eds., Cenozoic Basins of the Death Valley Region, Geological Society of America Special Paper 333, p. 289-300.

Blair, T.C., and Raynolds, R.G., 1999, Sedimentology, Stratigraphy, and paleotectonic implications of Neogene fan-delta and lacustrine deposits of the Hole in the Wall and Wall Front Members, Furnace Creek basin, Death Valley, California, in Wright, L.A. and Troxel, B.W., eds., Cenozoic Basins of the Death Valley Region, Geological Society of America Special Paper 333, p. 127-168.
Blakely, R.J., and McKee, E.H., 1985, Subsurface structural features of the Saline Range and adjoining regions of eastern California as interpreted from isostatic residual gravity anomalies: Geology, v. 13, p. 781-785.

Bohannon, R.G., and Parsons, T., 1995, Tectonic implications of post-30 Ma Pacific and North American relative plate motions: Geological Society of America Bulletin, v. 107, p. 937-959.

Brady, R.H., III, 1986, Stratigraphy and tectonics of the northern Avawatz Mountains at the intersection of the Garlock and Death Valley faults, San Bernardino, California, in Troxel, B. W., ed., Guidebook, Quaternary tectonics of southern Death Valley: Friends of the Pleistocene Pacific Cell, p. 1-12.

Brady, R.H., III, and Troxel, B.W., 1999, The Miocene Military Canyon Formation: Depocenter evolution and constraints on lateral faulting, southern Death valley, California, in Wright, L. A. and Troxel, B. W., eds., Geological Society of America Special Paper 333, p. 277-288.

Burchfiel, B.C., Hamill, G.S., and Wilhelms, D.E., 1983, Structural geology of the Montgomery Mountains and the northern half of the Nopah and resting Spring Ranges, Nevada and California: Geological Society of America Bulletin, v. 94, p. 1,359-1,376.

Burchfiel, B.C., Hodges, K.V., and Royden, L.H., 1987, Geology of Panamint Valley-Saline Valley pull-apart system, California: Palinspastic evidence for low-angle geometry of a Neogene range-bounding fault: Journal of Geophysical Research, v. 92, no. B10, p. 10,422-10,426.

Carl, B.S., and Glazner, A.F., 2002, Extent and significance of the Independence dike swarm, in Glazner, A.F., Walker, J.D., and Bartley, J.M., eds., Geologic Evolution of the Mojave Desert and southwestern Basin and Range: Geological Society of America Memoir 195, p. 117-130.

Cemen, I., 1983, Stratigraphy, geochronology, and structure of selected areas of the Death Valley region, eastern California, western Nevada, and implications concerning Cenozoic tectonic of the region [Ph.D. Thesis]: University Park, Pennsylvania State University, $235 \mathrm{p}$.

Cemen, I., Wright, L.A., and Prave, A.R., 1999, Stratigraphy and tectonic implications of the latest Oligocene and early Miocene sedimentary succession, southernmost Funeral Mountains, Death Valley region, California, in Wright, L. A., and Troxel, B.W., eds., Cenozoic Basins of the Death Valley Region, Geological Society of America Special Paper 333, p. $65-86$. 
Cichanski, M., 2000, Low-angle range-flank faults in the Panamint, Inyo, and Slate ranges, California: Implications for recent tectonics of the Death Valley region: Geological Society of America Bulletin, v. 112, p. 871-883.

Christiansen, R.L., and Lipman, P.W., 1972, Cenozoic volcanism and plate-tectonic evolution of the western United States. II. Late Cenozoic: Philosophical Transactions for the Royal Society of London, v. A. 271, p. 249-284.

Davis, G.A., Fowler, T.K., Jr., Bishop, K., Brudos, T.C., Friedmann, S.J., Parke, M.L., and Burchfiel, B.C., 1993, Pluton pinning of an active Miocene detachment fault system, eastern Mojave desert, California: Geology, v. 21, p. 267-270.

Didericksen, B., 2005, Cross cutting relationships between low-angle normal faults in the Slate Range, eastern California: Geological Society of America Abstracts, v. 37, p. 70.

Drewes, H., 1963, Geology of the Funeral Peak Quadrangle, California, on the east flank of Death Valley: U. S. Geological Survey Professional Paper 413, 78 p., 2 plates.

Duffield, W.A., Bacon, C.R., and Dalrymple, G.B., 1980, Late Cenozoic volcanism, geochronology, and structure of the Coso range, Inyo County, California: Journal of Geophysical research, v. 85 , no. B5, p. 2,381-2,404.

Faulds, J.E., Smith, E.I., and Gans, P.B., 1999, Spatial and temporal patterns of magmatism and extension in the northern Colorado river extensional corridor, Nevada and Arizona: A preliminary report, in Nevada Petroleum Society 1999 Field Trip Guidebook, p. 171-183.

Fowler, T.K., Jr., and Calzia, J.P., 1999, Kingston Range detachment fault, southeastern Death Valley region, California-Relation to Tertiary deposits and reconstruction of initial dip, Geological Society of America Special Paper 333 , p. 245-258.

Friedmann, S.J., 1999, Sedimentology and stratigraphy of the Shadow Valley basin, eastern Mojave Desert, California, in Wright, L.A. and Troxel, B.W., eds., Geological Society of America Special Paper 333, p. 213-244.

Friedmann, S.J., Davis, G.A., and Fowler, T.K., Jr., 1996, Geometry, paleodrainage, and geologic rates from the Miocene Shadow Valley supradetachment basin, eastern Mojave Desert, California: Geological Society of America Special Paper 303, p. 85-105.

Fridrich, C.J., 1999, Tectonic evolution of the Crater Flat basin, Yucca Mountain region, Nevada, in Wright, L.A. and Troxel, B.W., eds., Cenozoic basins of the Death Valley region: Geological Society of America Special Paper 333, p. 169-195.
Fridrich, C.J., Minor, S.A., Slate, J.L. and Ryder, P.L., 2007, Geologic Map of Oasis Valley Spring-Discharge Area and Vicinity, Nye County, Nevada: U. S. Geological Survey Scientific Investigations Map 2957, scale 1:50,000.

Fridrich, C.J., Thompson, R.A., Slate, J.L., Berry, M.E., and Machette, M.N., 2008, Preliminary geologic map of the southern Funeral Mountains and adjacent ground-water discharge areas, Inyo County, California and Nye County, Nevada: U. S. Geological Survey Open-File Report 20081366, scale 1:50,000.

Fridrich, C.J., Thompson, R.A., Slate, J.L., Berry, M.E., Machette, M.N., and Miggins. D.P., in press, Geologic map of the southern Funeral Mountains and adjacent groundwater discharge areas, Inyo County, California and Nye County, Nevada: U. S. Geological Survey Scientific Investigations Map, scale 1:50,000.

Gans, P.B., and Bohrson, W.A., 1998, Suppression of volcanism during rapid extension in the Basin and Pange province, United States: Science, v. 279, p. 66-68.

Glazner, A.F., Walker, J.D., Bartley, J.M., and Fletcher, J.M., 2002, Cenozoic evolution of the Mojave block of southern California, in Glazner, A.F., Walker, J.D., and Bartley, J.M., eds., Geologic Evolution of the Mojave Desert and southwestern Basin and Range: Geological Society of America Memoir 195, p. 19-42.

Hammond, W.C., and Thatcher, W., 2004, Contemporary tectonic deformation of the Basin and Range province, western United States-10 years of observation with the Global Positioning system: Journal of Geophysical Research, v. 109, 21 p.

Hardyman, R.F., and Oldow, J.S., 1991, Tertiary tectonic framework and Cenozoic history of the central Walker Lane, Nevada, in Raines, G.I., Lisle, R.E., Schafer, R.W., and Wilkinson, W.H., eds., Geology and ore deposits of the Great Basin: Geological Society of Nevada Symposium Proceedings, v. 1, p. 279-301.

Henry, C.D., Faulds, J.E., and dePolo, C.M., 2007, Geometry and timing of strike-slip and normal faults in the northern Walker Lane, northwestern Nevada and northeastern California: Strain partitioning or sequential extensional and strike-slip deformation?, in Till, A.B., Roeske, S.M., Sample, J.C., and Foster, D.A., eds., Exhumation associated with continental strike-slip fault systems, Geological Society of America Special Paper 434, p. 59-79.

Hinrichs, E.N., 1968, Geologic map of the Camp Desert Rock Quadrangle, Nye County, Nevada: U. S. Geological Survey Map GQ-726, scale 1:62,500. 
Hoisch, T.D., and Simpson, C., 1993, Rise and tilt of metamorphic rocks in the lower plate of a detachment fault in the Funeral Mountains, Death Valley, California: Journal of Geophysical Research, v. 98, no. B4, p. 6,805-6,827.

Hoisch, T.D., Heizler, M.T., and Zartman, R.E., 1997, Timing of detachment faulting in the Bullfrog Hills and Bare Mountain area, southwest Nevada: Inferences from ${ }^{40} \mathrm{Ar} /{ }^{39} \mathrm{Ar}$, $\mathrm{K}-\mathrm{Ar}, \mathrm{U}-\mathrm{Pb}$, and fission track thermochronology: Journal of Geophysical Research, v. 102, no. B4, p. 2,815-2,833.

Holm, D.K., and Dokka, R.K., 1993, Interpretation and tectonic implications of cooling histories-An example from the Black Mountains, Death Valley extended terrane, California: Earth and Planetary Science Letters, v. 116, p. 63-80.

Holm, D.K., Fleck, R.J., and Lux, D.R., 1994, The Death Valley turtlebacks reinterpreted as Miocene-Pliocene folds of a major detachment surface: Journal of Geology, v. 102, p. 718-727.

Holm, D.K., Snow, J.K., and Lux, D.R., 1992, Thermal and barometric constraints on the intrusive and unroofing history of the Black Mountains: Implications for the timing, initial dip, and kinematics of detachment faulting in the Death Valley region, California: Tectonics, v. 11, p. 507-522.

Hudson, M.R., Sawyer, D.A., and Warren, R.G., 1994, Paleomagnetism and rotation constraints for the middle Miocene southwestern Nevada volcanic field: Tectonics, v. 13, p. $258-277$.

Knott, J.R., Sarna-Wojcicki, A.M., Meyer, C.E., Tinsley, J.C. III, Wells, S.G., and Wan, E., 1999, Late Cenozoic stratigraphy and tephrochronology of the western Black Mountains piedmont, Death Valley, California: Implications for the tectonic development of Death Valley, in Wright, L.A. and Troxel, B.W., eds., Cenozoic basins of the Death Valley region: Geological Society of America Special Paper 333, p. 345-366.

Longwell, C.R., Pampeyan, E.H., Bowyer, B., and Roberts, R.J., 1965, Geology and mineral deposits of Clark County, Nevada: Nevada Bureau of Mines Bulletin 62, 218 p.

Luckow, H.G., Pavlis, T.L., Serpa, L.F., Guest, B., Wagner, D.L., Snee, L., Hensley, T.M., and Korjenkov, A., 2005, Late Cenozoic sedimentation and volcanism during transtensional deformation in Wingate Wash and the Owlshead Mountains, Death Valley: Earth-Science Reviews, v. 73, p. $177-219$.

Lundstrom, S.C., and Warren, R.G., 1994, Late Cenozoic evolution of Fortymile Wash: major change in drainage pattern in the Yucca Mountain, Nevada region during late Miocene volcanism, Proceedings of the Fifth International Conference on High Level Radioactive Waste Management, p. 2,121-2,130.
McAllister, J.F., 1970, Geology of the Furnace Creek borate area, Death Valley, Inyo County, California: California Division of Mines and Geology Map Sheet 14, scale $1: 24,000,9 \mathrm{p}$.

McKee, E.H., 1971, Tertiary igneous chronology of the Great Basin of western United States-Implications for tectonic models: Geological Society of America Bulletin, v. 82, p. 3,497-3,502.

McKenna, L.W. and Hodges, K.V., 1990, Constraints of the kinematics and timing of late Miocene-Recent extension between the Panamint and Black Mountains, in Wernicke, B.P., ed., Basin and Range tectonics near the latitude of Las Vegas, Nevada: Geological Society of America Memoir 176, p. 363-376.

Machette, M.N., Johnson, M.L., and Slate, J.L., 2001, Quaternary and late Pliocene geology of the Death Valley region: Recent observations on tectonics, stratigraphy, and lake cycles: Guidebook for the 2001 Pacific Cell - Friends of the Pleistocene Field Trip, U.S. Geological Survey Open-File Report 01-52, $246 \mathrm{p}$.

Maldonado, F., 1990, Geologic map of the northwest quarter of the Bullfrog 15-minute quadrangle, Nye County, Nevada: U.S. Geological Survey Map I-1985, scale 1:24,000.

Maldonado, F. and Hausback, B.P., 1990, Geologic map of the northeast quarter of the Bullfrog 15-minute quadrangle, Nye County, Nevada: U.S. Geological Survey Map I-2049, scale $1: 24,000$.

Mammerickx, J., and Klitgord, K.D., 1982, Northern East Pacific Rise: Evolution from 25 m.y. B.P. to the Present: Journal of Geophysical Research, v. 87, p. 6,751-6,759.

Menges, C.M., 2008, Multistage late Cenozoic evolution of the Amargosa River drainage, southwestern Nevada and eastern California, in Reheis, M.C., Hershler, R., and Miller, D.M., eds., Late Cenozoic Drainage History of the Southwestern Great Basin and Lower Colorado River Region: Geologic and Biotic Perspectives: Geological Society of America Special Paper 439.

Menges, C.M., Fridrich, C.J., Blakely, R.J., and Thompson, R.A., 2003, Late Quaternary Surface Rupture and Associated Transpressive Uplift on a Section of the State Line Fault in the south-central Amargosa Desert Basin, Southwestern Nevada: EOS, Transactions American Geophysical Union Fall Meeting 2003, v. 84, p. 988-989.

Menges, C.M., Pavlis, T.L., McMackin, M.R., Serpa, L., and Bennett, R.A., 2005, Geomorphic and structural evidence for significant neotectonic contractional strain within southern Death Valley and bordering areas, eastern California: Geological Society of America Abstracts with Programs, v. 37 , no. 7 , p. 69 . 
Menges, C.M., Pavlis, T.L., McMackin, M.R., and Serpa, L., 2006, Contractional strain related to interference of intersecting sets of strike-slip faults in the southern Death Valley region, California: Eos (Transactions, American Geophysical Union), v. 87, no. 52, Fall Meeting Supplement, Abstract T21B-0411.

Miller, D.M., Menges, C.M., and McMackin, M.R., 2007, Geomorphology and tectonics at the intersection of Silurian and Death Valleys: Field trip road log, in Miller, D.M., Menges, C.M., and McMackin, M.R., eds., Geomorphology, and Tectonics at the Intersection of Silurian and Death Valleys: Pacific Cell, Friends of the Pleistocene, 2005 Guidebook: U.S. Geological Survey Open-File Report 2007-1424, p. 8-45.

Minor, S.A., Hudson, M.R., and Fridrich, C.J., 1997, Fault-slip data, paleomagnetic data, and paleostress analyses bearing on the Neogene tectonic evolution of northern Crater Flat basin, southern Nevada: U. S. Geological Survey Open-File Report 97-285, 41 pp, 4 appendices.

Monastero, F.C., Walker, J.D., Katzenstein, A.M., and Sabin, A.E., 2002, Neogene evolution of the Indian Wells Valley, east-central California, in Glazner, A.F., Walker, J.D., and Bartley, J.M., eds., Geologic Evolution of the Mojave Desert and southwestern Basin and Range: Geological Society of America Memoir 195, p. 199-228.

Morrison, R.B., 1999, Lake Tecopa: Quaternary geology of Tecopa Valley, California, a multimillion-year record and its relevance to the proposed nuclear-waste repository at Yucca Mountain, Nevada, in Wright, L.A. and Troxel, B.W., eds., Cenozoic Basins of the Death Valley Region, Geological Society of America Special Paper 333, p. 301-344.

Murray, D.A., 2002, Oligocene to lower Miocene sratigraphy and extensional basin development, southwestern Nevada and southeastern California: [PhD thesis] Purdue University, West Lafayette, Indiana, 149 p., 5 appendices.

Niemi, N.A., 2002, Extensional tectonics in the Basin and Range province and the Geology of the Grapevine Mountains, Death Valley region, California and Nevada: [PhD Thesis] California Institute of Technology, Pasadena, California, 344 p., one 1:50,000 scale map.

Niemi, N.A., Wernicke, B.P., Brady, R.J., Saleeby, J.B., and Dunne, G.C., 2001, Distribution and provenance of the middle Miocene Eagle Mountain Formation, and implications for regional kinematic analysis of the Basin and Range province: Geological Society of America Bulletin, v. 113, p. 419-442.
Numelin, T., Kirby, E., Walker, J.D., and Diderickson, B., 2007, Late Pleistocene slip on a low-angle normal fault, Searles Valley, California: Geosphere, v. 3, p. 163-176.

Oakes, E.H., 1977, Geology of the northern Grapevine Mountains, northern Death Valley, California: [M. S. Thesis] University of Wyoming, Laramie, Wyo., 107 p. 2 plates.

Page, W.R., Lundstrom, S.C., Hariis, A.G., Langenheim, V.E., Workman, J.B., Mahan, S.A., Paces, J.B., Dixon, G.L., Rowley, P.D., Burchfiel, B.C., Bell, J.W., and Smith, E.I., 2005, Geologic and geophysical maps of the Las Vegas 30 ' X 60' quadrangle, Clark and Nye Counties, Nevada, and Inyo County, California: U. S. Geological Survey Scientific Investigations Map 2814, scale 1:100,000.

Pakiser, L.C., Kane, M.F., and Jackson, W.H., 1964, Structural geology and volcanism of Owens Valley region, CaliforniaA geophysical study: U. S. Geological Survey Professional Paper 438, 68 p., 3 plates.

Phillips, F.M., 2009, Geological and hydrological history of the paleo-Owens River drainage since the late Miocene: Geological Society of America Bulletin, v. 121, p. 1,0131,033 .

Prave, A.R., and McMackin, M.R., 1999, Depositional framework of mid- to late Miocene strata, Dumont Hills and southern margin of the Kingston Range: Implications for the tectonostratigraphic evolution of the southern Death Valley region, in Wright, L.A. and Troxel, B.W., eds., Cenozoic Basins of the Death Valley Region, Geological Society of America Special Paper 333, p. 259-275.

Reheis, M.C., and Sawyer, T.L., 1997, Late Cenozoic history and slip rates of the Fish Lake Valley, Emigrant Peak, and Deep Springs fault zones, Nevada and California: Geological Society of America Bulletin, v. 109, p. 280-299.

Reinert, E., Cowan, D.S., and Reiners, P.W., 2003, Transpression within the eastern California shear zone and lowtemperature thermochronometry of the Avawatz Mountains, Southern California, USA: Geological Society of America, Abstracts with Programs, v. 35, no. 4, p. 64.

Reynolds, M.W., 1969, Stratigraphy and structural geology of the Titus and Titanothere Canyons area, Death Valley, California [Ph.D. dissert.]: Berkeley, University of California, Berkeley, CA, 310 p.

Reynolds, U.V., 1974, Recurrent middle and late Cenozoic deformation, northeastern Death Valley, California-Nevada: Geological Society of America Abstracts with Programs, v. 6, p. 241-242. 
St. Amand, P., and Roquemore, G.R., 1979, Tertiary and Holocene development of the southern Sierra Nevada and Coso Range, California: Tectonophysics, v. 52, p. 409-410.

Sawyer, D.A., Fleck, R.J., Lanphere, M.A., Warren, R.G., Broxton, D.E., and Hudson, M.R., 1994, Episodic caldera volcanism in the Miocene southwestern Nevada volcanic field: revised stratigraphic framework, ${ }^{40} \mathrm{Ar} /{ }^{39} \mathrm{Ar}$ geochronologic framework, and implications for magmatism and tectonism: Geological Society of America Bulletin, v. 106, p. $1,304-1,318$.

Saylor, B.Z., and Hodges, K.V., 1994, ${ }^{40} \mathrm{Ar} /{ }^{39} \mathrm{Ar}$ age constraints on the depositional history of the Titus Canyon Formation, death valley, California: Geological Society of America Abstracts with programs, v. 26, p. 88.

Snow, J.K. and Lux, D.R., 1999, Tectono-sequence stratigraphy of Tertiary rocks in the Cottonwood Mountains and northern Death Valley area, California and Nevada, in Wright, L.A. and Troxel, B.W., eds., Cenozoic Basins of the Death Valley Region, Geological Society of America Special Paper 333, p. 17-64.

Snow, J.K., and Wernicke, B.W., 2000, Cenozoic tectonism in the central Basin and Range: Magnitude, rate, and distribution of upper crustal strain: American Journal of Science, v. 300, p. 659-719.

Snow, J.K., and White, C., 1990, Listric normal faulting and synorogenic sedimentation, northern Cottonwood Mountains, Death Valley region, California, in Wernicke, B. P., ed., Basin and Range extensional tectonics near the latitude of Las Vegas, Nevada: Geological Society of America Memoir 176, p. 413-445.

Snyder, N.P. and Hodges, K.V., 2000, Depositional and tectonic evolution of a suprdetachment basin: ${ }^{40} \mathrm{Ar} /{ }^{39} \mathrm{Ar}$ geochronology of the Nova Formation, Panamint Range, California: Basin Research, v. 12, p. 19-30.

Spencer, J.E., 1993, Stratigraphy of the Avawatz Formation, southern Death Valley region, southeastern California, in Sherrod, R., and Neilson, J.E., eds., Tertiary Stratigraphy of highly extended terranes, California and Nevada: U. S. Geological Survey Bulletin, 2053, p. 19-20.

Stewart, J.H., 1983, Extensional tectonics in the Death Valley area, California: Transport of the Panamint Range structural block 80 km northwestward: Geology, v. 11, p. 153-157.

Stewart, 1988, Tectonics of the Walker Lane belt, western Great Basin-Mesozoic and Tertiary deformation in a zone of shear, in Ernst, W. G., ed., Metamorphism and crustal evolution of the western United States, Rubey Vol. VII; Englewood Cliffs, New Jersey, Prentice-Hall, p. 683-713.
Stock, C. and Bode, F.D., 1935, Occurrence of lower Oligocene mammal-bearing beds near Death Valley, California: National Academy of Sciences Proceedings, v. 21, p. 571-579.

Stockli, D.F., Dumitru, T.A., McWilliams, M.O., and Farley, K.A., 2003, Cenozoic tectonic evolution of the White Mountains, California and Nevada: Geological Society of America Bulletin, v. 115, p. 788-816.

Tschanz, C.M., and Pampeyan, E.H., 1970, Geology and mineral deposits of Lincoln County, Nevada: Nevada Bureau of Mines Bulletin 73, 187 p.

Wagner, D. L., 1988, Evidence for late Cenozoic extension across Wingate wash, Death Valley region, southeastern California, in Gregory, J. L., and Baldwin, E. J., eds., Geology of the Death Valley region: South Coast Geological Society 1988 Fieldtrip Guidebook, p. 243-259.

Walker, P., 1936, Fossil redwood from Nevada: The Mineralogist, v. 4, p. 7-8.

Ward, P.L., 1991, On plate tectonics and the geologic evolution of southwestern North America: Journal of Geophysical Research, v. 96, p. 12,479-12,496.

Weiss, S.I., Noble, D. C., Worthington, J.E., IV, and McKee, E.H., 1993, Neogene tectonism from the southwestern Nevada volcanic field to the White Mountains, California, Part 1. Miocene volcanic stratigraphy, paleotopography, extensional faulting, and uplift between northern Death Valley and Pahute Mesa, in Lahren, M.M., Trexler, J.H., Jr., and Spinosa, C., eds., Crustal Evolution of the Great Basin and Sierra Nevada: Cordilleran/Rocky Mountain Section, Geological Society of America Guidebook, Department of Geological Sciences, University of Nevada, Reno, p. 353-382.

Wernicke, B.P., Snow, J.K., Axen, G.J., Burchfiel, B.C., Hodges, K.V., Walker, J.D., and Guth, P.L., 1989, Basin and Range tectonics near the latitude of Las Vegas, Nevada: Geological Society of America Memoir 176, 81 p.

Workman, J.B., Fridrich, C.J., Slate, J.L., and Berry, M.E., 2004, New geologic mapping in the Montgomery Mountains, southern Nevada: Geological Society of America Abstracts with Programs, v. 36, no. 5, p. 584.

Wright, L.A. and Troxel, B.W., 1984, Geology of the northern half of the Confidence Hills quadrangle, Death Valley region, California; the area of the Amargosa Chaos: California Division of Mines and Geology Map Sheet 34, scale $1: 24,000,31 \mathrm{p}$. 
Wright, L.A., Greene, R.C., Cemen , I., Johnson, F.C., and Prave, A.R., 1999, Tectonostratigraphic development of the Miocene-Pliocene Furnace Creek basin and related features, in Wright, L.A. and Troxel, B.W., eds., Cenozoic Basins of the Death Valley Region, Geological Society of America Special Paper 333, p.87-114.

Wright, L.A., Thompson, R.A., Troxel, B.W., Pavlis, T.L., DeWitt, E.H., Otton, J.K., Ellis, M.A., Miller, M.G., and Serpa, L.F., 1991, Cenozoic magmatic and tectonic evolution of the east-central Death Valley region, California, in Walawender, M.J., and Hanan, B.B., eds., Geologic excursions in southern California and Mexico: San Diego, California, Geological Society of America 1991 Annual Meeting Guidebook, p. 93-127.

Wust, S., 1986, Regional correlation of extension directions in Cordilleran metamorphic core complexes: Geology, v. 14, p. $828-830$.

Yin, A., 1989, Origin of regional rooted low-angle normal faults: A mechanical model: Tectonics, v. 469-482.
Publishing support provided by:

Denver and Rolla Publishing Service Centers

For more information concerning this publication, contact:

Center Director, USGS Geology and Environmental Change Science Center

Box 25046, Mail Stop 980

Denver, CO 80225

(303) 236-5344

Or visit the Geology and Environmental Change Science Center Web site at: http://esp.cr.usgs.gov/ 


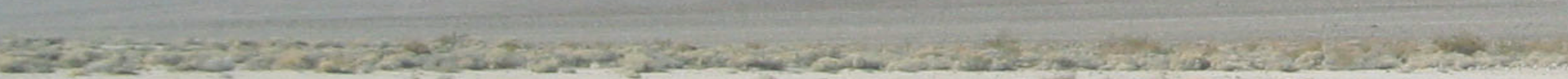
areses -

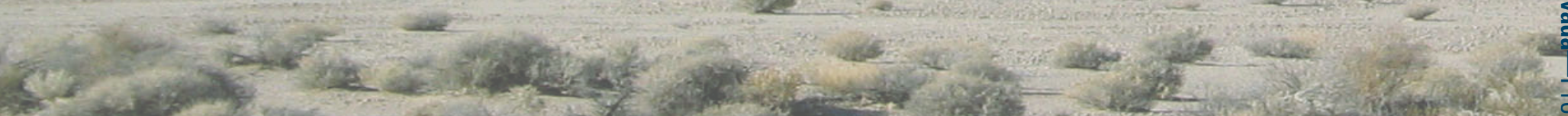

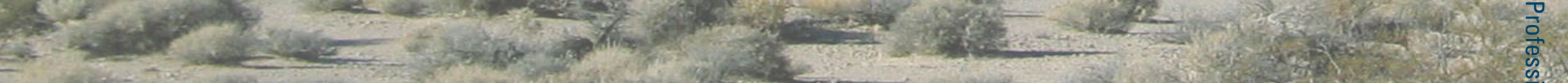

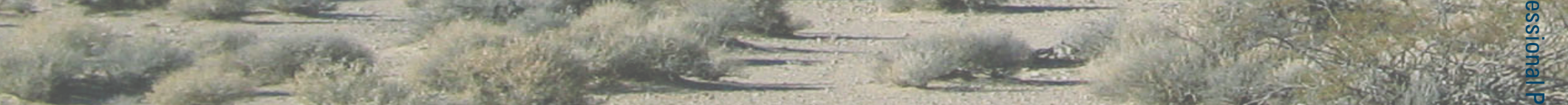

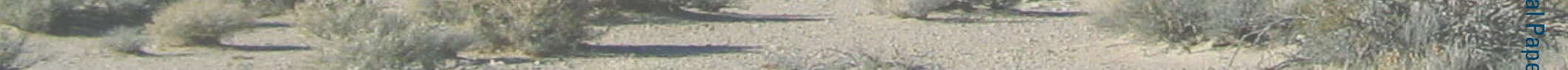

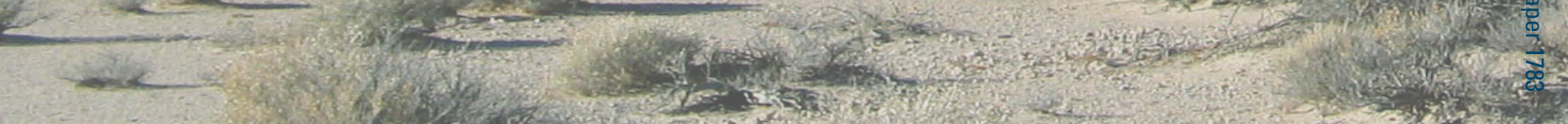

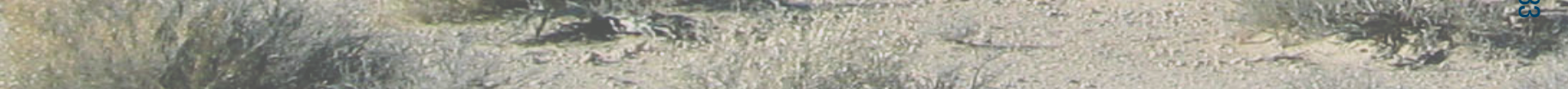

